1920

FO

R. S. Funk

A Study of the Methods for Determining the Diastasic Action by Bacteria 



\title{
A STUDY OF THE METHODS FOR DETERMINING THE DIASTASIC ACTION OF BACTERIA
}

\author{
BY
}

RUTH SCOVELL FUNK

B. S. University of Illinois, 1917

\section{THESIS}

Submitted in Partial Fulfillment of the Requirements for the

Degree of

MASTER OF SCIENCE

IN BACTERIOLOGY

IN

THE GRADUATE SCHOOL

OF THE

UNIVERSITY OF ILLINOIS

1920 



\section{$19 \geq 0$ \\ F96 \\ UNIVERSITY OF ILLINOIS}

THE GRADUATE SCHOOL

June 1, 1990.

1 HEREBY RECOMMEND THAT THE THESIS PREPARED UNDER MY SUPERVISION BY_Ruth Scovell Funk

ENTITLED A Study of Methods for Determining Diastasie Action of Bacteria.

BE ACCEPTED AS FULFILLING THIS PART OF THE REQUIREMENTS FOR THE DEGREE OF_ Master of Science

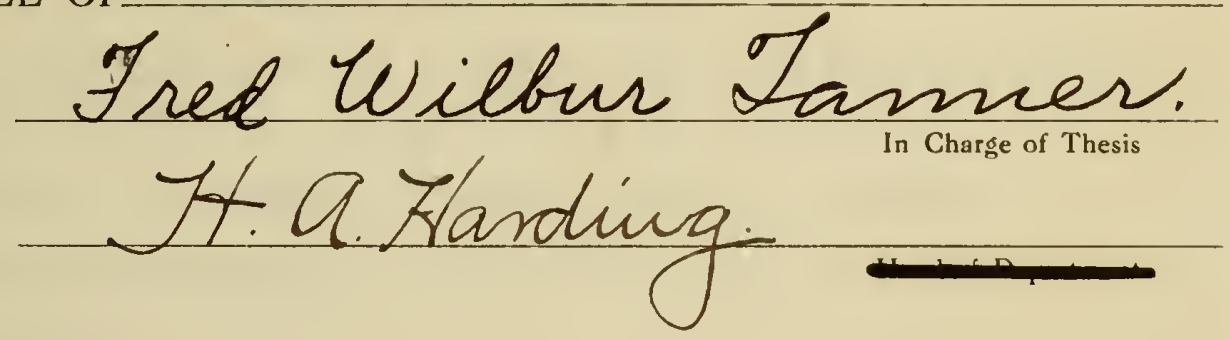

Recommendation concurred in*

Committee

on

Final Examination* 

TABLE OH CONTENTS.

I. Title Page.

II. Certificate of Approval.

II. Table of contents.

IV. Iist of Tables and Illustrations.

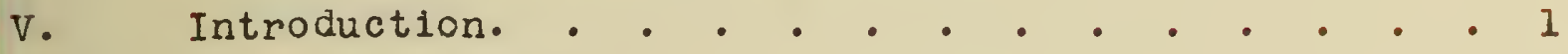

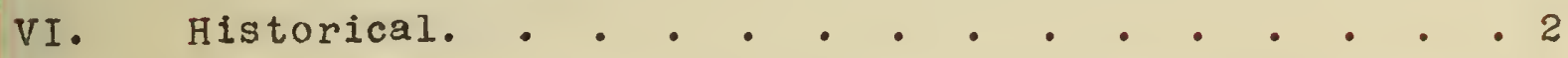

A Starch decomposition by other enzymes than bacterial. . . . . . . . . . . . . . . 2

B Starch decomposition by bacterial enzymes. - . 6

Significance in pure culture studies. . . . 8

Significance in the industries. . . . . . 9

C Methods which have been used for determining diastasic action by bacteria. . . . . . . 10

VII. Chemistry of Starch (Biochemistry) . • . . . . 14

A Why starch has to be broken down and why bacteria break $1 t$ up. . . . . . . . . • . . . 14

B Chemistry of starch decomposition by enzymes. . 15

VII. The diastasic enzymes. - • • • • . • . • . 22

IX. Experimental. • • • • • • • • • • • • .27

A Effect of different amounts of starch on the action of diastasic enzymes on the starch agar plate. . 27

B Effect of concentrated agar solutions on the action of diastasic enzymes on the starch agar plate. . 32

C Effect of the length of incubation period on the action of diastasic enzymes on the starch agar plate. . . . . . . . . . 36

D Effect of different starches in the action of diastasic enzyues on the starch plate. . . . . 39 

E Study of diastasic action in synthetic media. . 46

F Study of different methods used in determining diastasic action. . . . . . . . . 57

$G$ Study of varying the amount of peptone on the diastasic action of bacteria, using the dot and streak inoculation. . . . . . . . 66

Discussion. • . . . . . . . . . . 77

XI.

Conclusion. • . • • . . . . . . . . . 79

XII.

Bibliography 
Digitized by the Internet Archive in 2013 
List of Tables and Illustrations.

I. Table Showing Diastasic Action with $0.2 \%-4.0 \%$ Starch

Inclusive, and $11 / 2 \%$ Agar.

II. Table Showing Diastasic Action with.01\%-1.0\% Starch

Inclusive and 1 1/2\% Agar.

III. Figure Showing the Effect of Different Amounts of 3 tarch on the Diastasic Action of B. vulgatus on 1 1/2\% Agar.

IV. Figure Showing the Effect of Length of Incubation Period on the Diastasic Action of B. vulgatus with 1 1/2\% Agar and $2 \%$ Potato Starch.

V. Table Showing Diastasic Action on $21 / 2 \%$ Agar and $0.5 \%-$ 2. $0 \%$ Starch Inclusive.

VI. Table Showing Growth and Diastasic Action on 1 1/2\% Agar with $1.0 \%$ and $2.0 \%$ Potato Starch. . . . . . . . .

VII. Figure Showing the Effect of Different Percentages of Agar on the Diastasic Action of Starch. ( 1 1/2\% and $21 / 2 \%$ Agar) 38

VII. Table Showing Growth and Diastasic Action After 1 and 2 days Incubation on $21 / 2 \%$ Agar with Various Starches. .

IX. Table Showing Growth and Diastasic Action After 7 days Incubation on $21 / 2 \%$ Agar with Different Starches. . .

X. Figure Showing the Effect of Different Starches on Diastasic Action of B. vulgatus on $21 / 2 \%$ Agar. . . . .

XI. Table Showing Diastasic Action in Frankel's Solution. .

XII. Table Showing Diastasic Action in Frankel's Solution After 9 and 12 Days Incubation. . . . . . . . . . 48

XIII.Table Showing Diastasic Action in Starch Broth After

5 Days Incubation.

XIV. Table Showing Diastasic Action in Starch Broth with 0.1$0.4 \%$ Starch Inclusive After 1, 2, and 3 Days Incubation. . 53

XV. Table Showing Diastasic Action According to Edson and Carpenter's Method.

XVI. Table Showing Growth and Diastasic Action with Waksman's Starch Plates. 


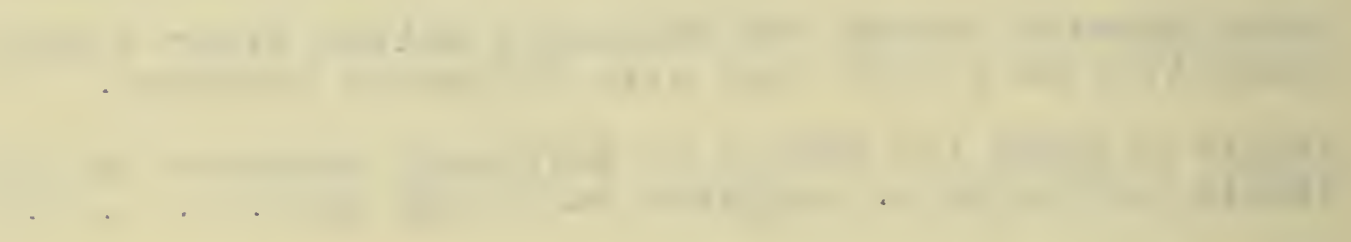




\section{List of Tables and Illustrations.}

XVII. Table Showing Diastasic Action with Waksman's Tube Method. • • • • • • • • • • • 61

XVIII. Table Showing Growth and Diastasic Action According to Crabill and Reed's Method. . . . . . . . 63

XIX. Table Showing Growth and Diastasic Action with the Dot Method of Inoculation. . . . . . . . . 65

XX.-XXVIII. Tables Showing Growth and Diastasic Action with Different Amounts of Peptone. . . . . . . 67-76 

Introduction.

Since the determination of the diastasic action of bacteria is a point in the determination of the Group Number* of bacteria by the Committee of the Revision of Chart Identification of Bacterial species of the Society of American Bacteriologists, and since it is used in pure culture studies, it seems advisable to study the methods which have been proposed for its determination. As is generally known, this physiological reaction has many difficulties connected with its determination. Obviously it would also be of much interest and importance to investigate the activities of an enzyme so wide spread in nature, in the animal and vegetable life. Such an investigation is beset with many difficulties. There are so many conditions which must be made constant in order that more accurate conslusions may be drawn from the premises. No claim is made that this report is exhaustive; an attempt has, however, been made into the subject to, perhaps, lay out the field and to determine the value of some of the methods which have been proposed by various bacterlologists. It is hoped that others will carry the work more nearly to completion and to determine the rest of the data needed to more accurately know the bacterial amylases.

The Group Number of the Soclety of American Bacteriologists is a convenient method for recording the salient charactera of an organism. It is constructed after the Dewey decimal system for cataloguing books. A discussion of it is given be Tanner in his Bacteriology and Mycology of Foods, John Wiley and Sons., Inc. New York City. 1919 

Historical.

A. Starch Decomposition by Enzymes Other Than Those of Bacterial origin.

Starch constitutes one-half to three-fourths of the solid matter of the ordinary grains, and at least three-fourths of the mature potato. Unchanged starch occurs in distinct granules, differing in different plants. These granules are not affected by cold water, but on warming, they absorb water, swell and burst, finally forming a colloidal or gelatinous mass called "starch paste". Starch, which is insoluble and indiffusible, is rendered solubie and diffusible by the digesting action of enzymes.

The discovery of these enzymes, diastases or amylases, was made in 1814 by Kirckhoff (1814) when he observed that germinating barley grains contained a principle which, when extracted, was capable of converting starch into sugar. Although this power was then thought to be due to some property of the gluten or grain, the study of it lald the foundation for the study of enzymes. Kirckhoff was also the first to study the transformation of starch by acids.

Dubrunfaut (1823) worked with the enzyme and noted that best results were obtained at $65^{\circ} \mathrm{C}--\mathrm{h}$ is work was the first scientific study of diastases.

Payen and Persoz, in 1833, were the first to prepare diastase from the extracts of germinated grain. They later found it in oats, wheat, corn and rice during germination. To this material, precipitated by alcohol, they gave the name "diastase". 

These men were the first to ascertain the stages of action. Musculus found that dextrin and sugar were produced simultaneously by diastasic activity. In 1871-2 Griessmeyer (1871), o'Sullivan (1872), and Brüke determined that at least two dextrins were found.

In 1874, von Gorup-Besanez found diastase in several other germinating seeds, Kosmann (1877), Baranetzky (1878) and Krauch (1879), established the presence of diastase in ordinary vegetabbe members of the plant, other than in the seeds.

Butkewitsch (1908) has given a noteworthy contribution on vegetable diastasic enzymes. Later investigators proved the ex1stence of two varieties of enzymes:

1. Diastase of translocation.

2. Diastase of secretion.

The diastase of translocation is the more widespread of the two diastases. It is in vegetative organs and in germinating seeds, appearing in the barley grain earlier than the other variety of diastase, and is more active at a lower temperature than the other. This enzyme dissolves the starch grains without corrosion, and is said to have a principal part in the transporting of starch from one part of the plant to another part. It has a slow action on starch paste, but readily converts soluble starch to sugar. Kjeldahl (1879) was the first to study with exactness the Influence of the acidity of the medium upon the diastase. The diastase of secretion is closely connected with germination, corroding starch grains and disintegrating them, before 

solution. Smith states that this diastase is formed by a special tissue, is excreted from this tissue into a region where it may prepare nutritive substances to be subsequently absorbed by the cells, which in the first place prepared the enzyme. It rapidly liquifles starch paste, acts best at $50^{\circ}-55^{\circ} \mathrm{C}$, and can withstand $70^{\circ} \mathrm{C}$

Diastase is widely distributed in the animal as well as in the plant body. In 1831, Leuchs first indicated the existence of animal diastase in the action of saliva transforming starch to sugar. In 1845, Mialhe prepared diastase from the secretion of the salivary gland by precipitation with alcohol, and named the starch transforming substance salivary diastase. In the same year Bouchardat and Sandras prepared diastase from the secretion of the pancreas. In 1863, Cohnhe1m prepared diastase in a purer form than had heretofore been done. In 1895, Pregl proved the existence of diastase in the intestinal juice of sheep. B1al, (1894), Rohman (1892), and Hamburger (1895), gave evidence of the existence of diastase in blood and lymph. Foster (1867), in the pericardial, pleural, and peritoneal fluids, and Cohnheim and Bechamp in fresh filtered urino.

Diastase is common among invertebrates. Boudourg (1899) found the enzyme in the pyloric tubes of certain Tellostean fisheg; Fredericq (1878) in the juices from sponges; Abelous and Heim (1892) In the eggs of certain crustaceans; and Müller and Masayama (1900) in the yolk of hens' egg.

Although in the animal body the two varieties of diastase have not been indicated so clearly as with the plants, two modes of action resembling those of the translocation and secretion in $\mathbf{p}$ lants 


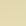
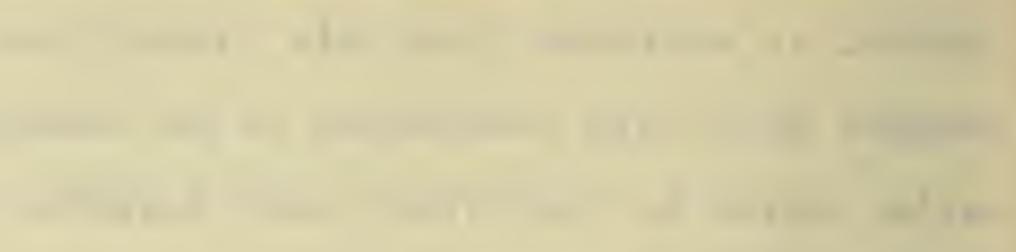

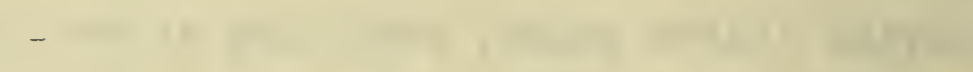

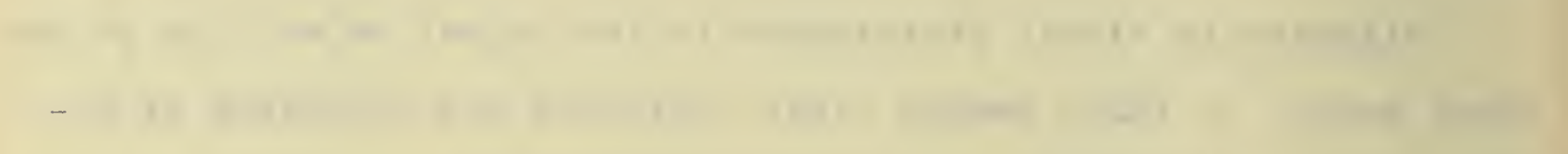

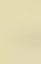

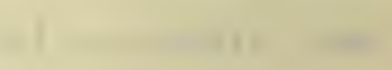
1 
have been found. An example of this is where the secretion of the salivary glands and pancreas are poured out into special regions of the alimentary canal to convert starch and glycogen into diffusible forms. In the case of tissues an enzyme is produced which acts only on the glycogen in the interior of the cell, and from the latter the diffustble products are removed by a species of translocation. The diastase of blood and lymph may be compared with the translocation diastase of plants. 

B. Starch Decomposition by Bacterial Enzymes.

In addition to theplant and animal diastases, starch is decomposed by the hydrolytic, extracellular, bacterial enzyme diastase. In 1882, Wortman showed that bacteria have the property of secretIng certain starch dissolving ferments. Because these bacteria were able to cause a change in starch paste and starch grains as well as in soluble starch, he concluded that the action of bacteria upon starch is by a ferment which is soluble in alcohol and water. Also, that bacteria show diastasic powers when starch grains are their only available food.

In 1883 Duclaux worked on the saccharifying power of Aspergillus niger. In 1890 Fermi recorded the examination of many species of bacteria for diastase, and found that the Prior's bac1llus, Koch's cholera vibrio, Bacillus ramosus, Bacillus megaterium, and a spirillum of cheese gave a positive test for diastase. Cavazzani in 1893, while working with an organism which he identified as probably being Bacillus magdis, found that it had the ability to convert starch into glucose. In 1895, Bourquelot and Herissey demonstrated the presence of diastase in the tissue of the fungus, Polyporus sulphurous. De Bary (1858) showed the presence of the enzyme from Aethalium, a myxomycete; Morris and Wells in yeast cells; Lauder, Brunton and MacFadyen (1889), and Nortman (1882) isolated it from bacteria, ahen grown on starch paste. Pfeffer (1896) noted the secretion of diastase by Bacilius megatherium. In 1901, Kohnstamm showed that fungi as well as bacteria secrete a starch destroying enzyme. 

In general, the action of bacterial enzymes is the same as that by digestive enzymes, etc. Starch which has the same chemical formula as cellulose is broken up into soluble sugars in the same way. The process, which is a gradual one, goes thru the cleavage products of dextrins and is then hydrolyzed to maltose. This hydrolysis may be expressed in chemical symbols as:

$$
2\left(\mathrm{C}_{6} \mathrm{H}_{12} \mathrm{O}_{6}\right)+\mathrm{N}\left(\mathrm{H}_{2} \mathrm{O}\right)_{n}+\text { diastase }={ }_{n}\left(\mathrm{C}_{12} \mathrm{H}_{22} \mathrm{O}_{11}\right)+\text { diastase. }
$$

As a rule, cazyme formation and bacterial growth run fairly parallel, but not always. Bacteria do not uniformly contain diastase nor is it present at all times in those which secrete 1 . In certain media, bacteria will grow, but do not form enzymes until, according to Jacoby (1917), certain other winerals (e. $g$. leucine) are added. He also states that leucine is necessary for the formation of the enzyme urease, but has no effect on its activity. 
$\mathrm{B}_{2}$. Significance in Pure Culture Study.

These diastasic enzymes are of significance in pure culture study because of the aid they give in the classification or groupIng of organisms thru certain characteristic reaction, as those called for in the Group number. By this physiologic function microörganisms either are or are not classed as those producing diastasic enzymes.

As stated by the Classification Committee of the Society of American Bacteriologists, the diastasic action presents the greatest difficulties of the various physiological reactions selected for the determination of an organism. 

$B_{3}$. Significance in the Industries.

Diastasic enzymes may be of importance in the manufacturing of alcohol, wines, etc. The conversion of starch into maltose by the amblase of certain molds is of importance in the manufacturing of industrial alcohols. Several species of mucor, particularly M. rouxil and M. oryzae, and one species of aspergillus, A. oryzae, have been used for this purpose. Mucor boulard No. 5 , has been isolated from the mucors and bacteria on decomposing vegetable matter, especially that containing sugar and starch. In this way is formed from the starch, the sugar upon which yeast is to act. "The mucor rouxil is the characteristic mold of Chinese or Java yeast". The Japanese beer sake or rice beer is brought about by Aspergillus oryzae. "Pombe from Africa is produced by Schizosaccharomyces pombe." "The production of diastase in seeds during germination is used in the process of malting and brewing. "Takadiastase, a mixture of saccharifying enzymes from Asperigillus oryzae, a fungus called koji-yeast, saccharifles starch more energetically than malt-diastase does." Bread making is another instance of economic Importance in which the diastase from grains used convert some of the starch to sugar. The diastasic enzymes are of biological importance as shown somewhat by their occurrence. These enzymes as discovered by Claude Bernard, are widespread in the animal kingdom. They are in blood serum, muscle plasma, body fluids, organs, and also have been found in hens' eggs. 

C. Methods which Have Been Used for Determining Diastasic Action by Bacteria.

Various methods have been used for determining diastasic action by bacteria. Perhaps the one.most universal in use now is Allen's plate method. This consists of preparing a starch agar by adding $0.2 \%$ water soluble starch to a standard agar, sterilizing in the autoclave, pouring into petrie plates, and allowing to cool. After this, a streak two laches long is made with the organism being studied, after which the plates are incubated two days at $32^{\circ} \mathrm{C}$, and five days at $20^{\circ} \mathrm{C}$, then flooded with a saturated solution of Iodine in 50\% alcohol. A clear zone averaging more than $2 \mathrm{~mm}$. in width is classed as strong, while a width of $2 \mathrm{~mm}$. or less is marked as feeble, and the absence of a halo as absent. Edson and Carpenter (1918) found that a thin starch paste containing $2 \%$ thymol did not show diastasic action.

A nutrient Starch Jelly for the Study of Diastasic Action has been prepared by adding $1 \mathrm{gm}$. of clear aseptic potato starch to 10 c.c. portions of modified Uschinsky's Solution, plugged and heated for two hours for five successive days at $85^{\circ}-93^{\circ} \mathrm{C}$.

Müller (1908) used a method of placing the ferment solution in increasing amounts in test tubes, adding 5 c.c. of $1 \%$ starch paste to each tube and placing immediately in ice water until all were ready. The tubes were then placed in a water bath at $40^{\circ} \mathrm{C}$ for 30-60 min., diluted with water, and a drop of $\mathrm{N} / 10$ Iodine added and shaken. The strength of the ferment is fixed as that number of c.c. of starch paste which 1 c.c. of ferment solution can transform into dextrin in the given time. (Saliva was used as the ferment). 

Thatcher and Koch (1916) used a method for determing the

diastasic activity of extracts in which bacteria have been grown by adding to $25 \mathrm{c} . \mathrm{c}$. of $10 \%$ Lintner's starch solution of known acidity, $N / 20$ alkall and $20 \mathrm{c} . c$. of enzyme solution (extract) giving the optimum acidity for enzyme activity. This was placed at $40^{\circ} \mathrm{C}$ for $30 \mathrm{~min}$. and the enzyme activity stopped by bringing the acidity to $\mathrm{N} / 20$ acid, cooled to $20-22^{\circ} \mathrm{C}$ to precipitate proteins, an aliquot reduced with Fehling's and the amount of reduced copper determined by the Iodine method. The difference between the amount of copper reduced and that in the blank was considered due to the diastases secreted by the bacteria.

Crabill and Reed (1915) used a stock agar consisting of:

$\begin{array}{rc}1000 & \text { c.c. } \\ 0.5 & \text { gm. } \\ 1.0 & \text { " } \\ 0.5 & \text { " } \\ 0.01 & \text { "i } \\ 20.0 & \text {. }\end{array}$

distilled water. magnesium sulphate. di-potassium hydrogen phosphate.

potassium chloride. ferrous sulphate. agar.

To this filtered agar was added $20 \mathrm{gm}$. of corn starch in suspension in a little cold water sterilized in flasks and poured with frequent shaking directly into the sterile petrie dishes. As soon as hardened, the centers of the dishes were inoculated with the test organisms, inverted, and incubated from 2 to 5 days under bell jars.

waksman (1919) used the tube andplate method for the study of diastasic production in connection with the Studies in Metabolism of Actinomycetes, with Czapek's Solution ( $1 \mathrm{gm} . \mathrm{K}_{2} \mathrm{HPO}_{4}, 0.5 \mathrm{gm}$. $\mathrm{M}_{9} \mathrm{SO}_{4}, 0.5 \mathrm{gm} . \mathrm{KCL}, 0.01 \mathrm{gm}$. Fe SO $\mathrm{SO}_{4}, 2 \mathrm{gm}$. Na NO 3 to a liter of water ). 

In the tube method, $10 \mathrm{gm}$. of starch boiled in distilled water was added to a solution of the minerals, and the volume made to a liter. This solution was placed in test tubes of equal size, 10 c.c. to a tube, sterilized and inoculated. A control was compared with the inoculated incubated tubes, and the difference of heights of starch in the test tubes was taken as the diastasic action of the organism.

In the plate method, $1.2 \%$ agar was added to the liter of medium and poured into sterile petrie dishes (10-12 c.c. to a plate). These were cooled, inoculated, incubated and tested with Iodine and Potassium Iodide.

A study of the destruction of potato starch was made on sterllized potato cylinders in test tubes upon which cultures were then crushed in porcelain mortars and 50 c.c. of water added to separate the particles so that the effect of Iodine could easily be seen. The presence of unchanged starch was determined by the gradual addition of a weak solution of Iodine and Potassium Iodide. After a sufficient amount was added to satisfy some of the other" compounds which were present the starch grains turned a blue-black. The extent of the reduction of the starch by the bacterial growth is estimated on the basis of similar tests of uninoculated potato cylinders. This method was also worked on by Dr. E. F. Smith (1905).

Müller tested diastasic ferment action by keeping a mixture of starch and water (about $10 \%$ ) at $55^{\circ}$ for from 1 to 2 days, stirring, pouring into petrie dishes, closing and keeping in a hot air bath at $85-90^{\circ}$ for from 1 to 2 hrs. The excess of water was poured off; after cooling, the inoculum was put upon the surface, 


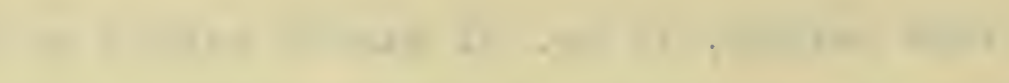

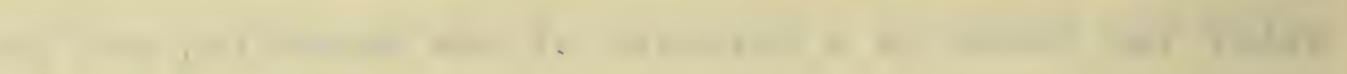
4. |

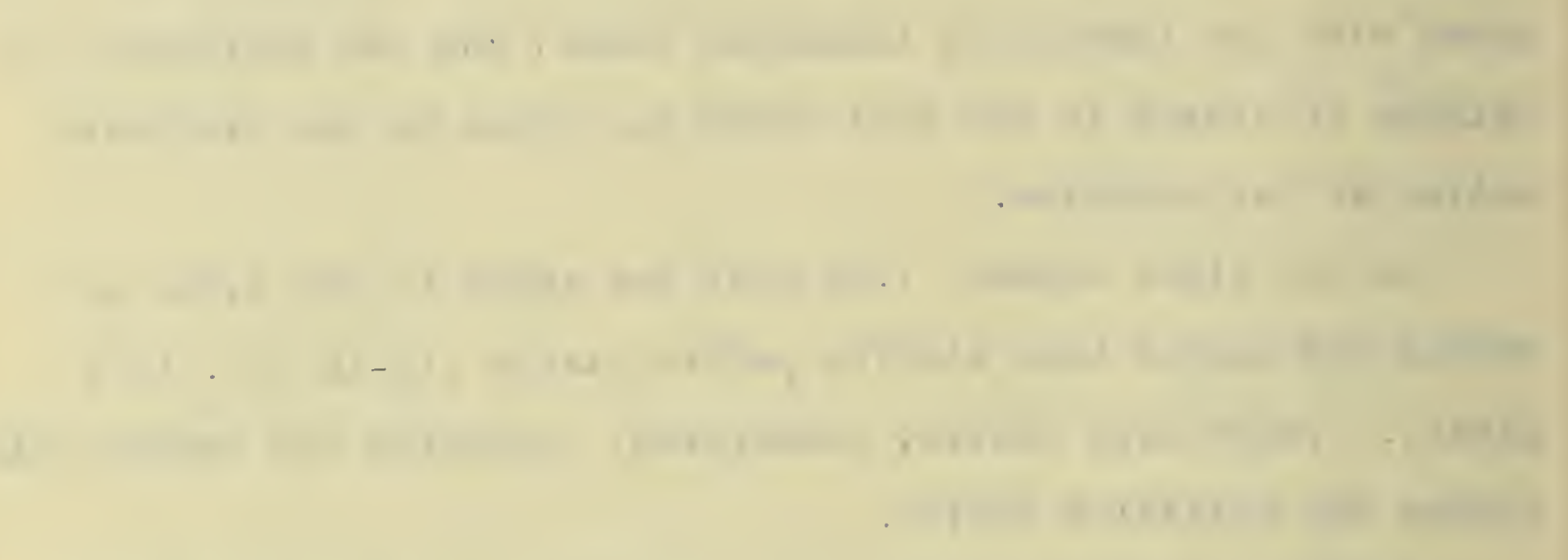


and the furrow caused by Iiquefaction of the paste was the evidence of enzyme activity. 

Chemistry of Starch. (Blochemistry).

A. Why Starch has to be Broken Down and Why Bacteria Break It Up.

Starch in its original form cannot be used by cells because they depend upon soluble food, since they have no ineans of incorporating insoluble compounds. This starch, which serves in the nutrition of almost all aninals and plants, is not directly assimilable. All living cella secrete enzynes, and these agents dissolve or hydrolyze the insoluble starch to maltose by means of the enzyme diastase. This extracellular, hydrolysis process yields very little energy, but is a preliminary process to the getting of energy. The product, maltose, is further acted upon by intracellular enzymes or by oxidation, and much energy is evolved. The excess of energy in this process over that used in the hydrolysis is the energy available for the cell in building up new tissue or cell protoplasm.

This breaking down of starch by enzymes is then a preparatory process to the securing of energy, as a result of which process, digestion or fermentation takes place, and energy available for cell use is given off; also the substances formed by the diastases are assimilable and suitable for the fornation of new tissue by the cells. (This preparatory process, however, has no direct relation to the intracellular food digestion or fermentation). Starch then must be broken down to become utilizable by cells, and bacterla break it up to obtain energy. 


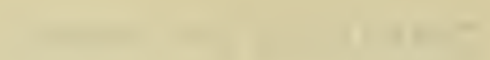

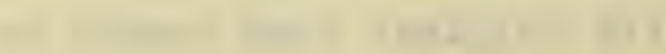

\section{.}

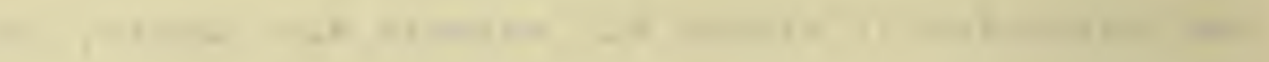

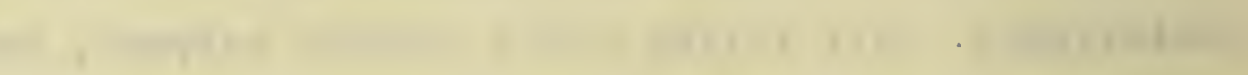

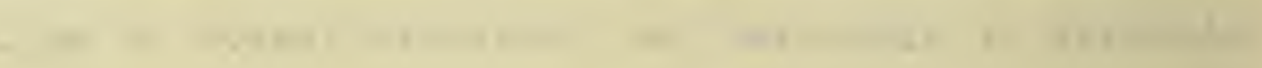
.

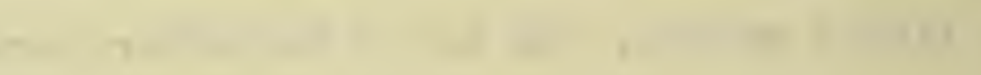

.

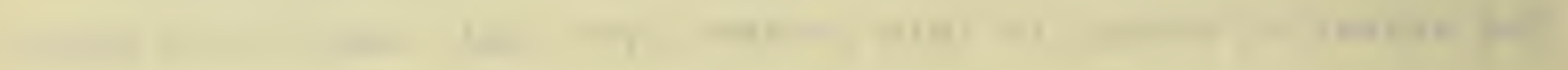

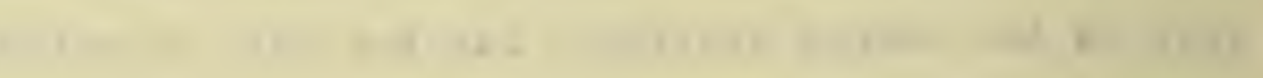

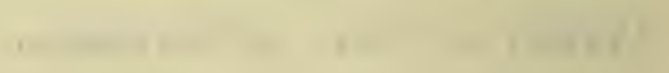

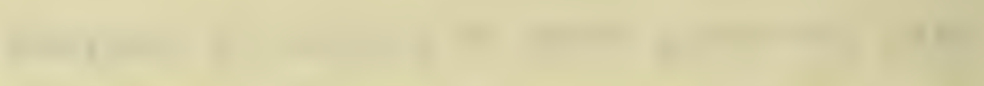

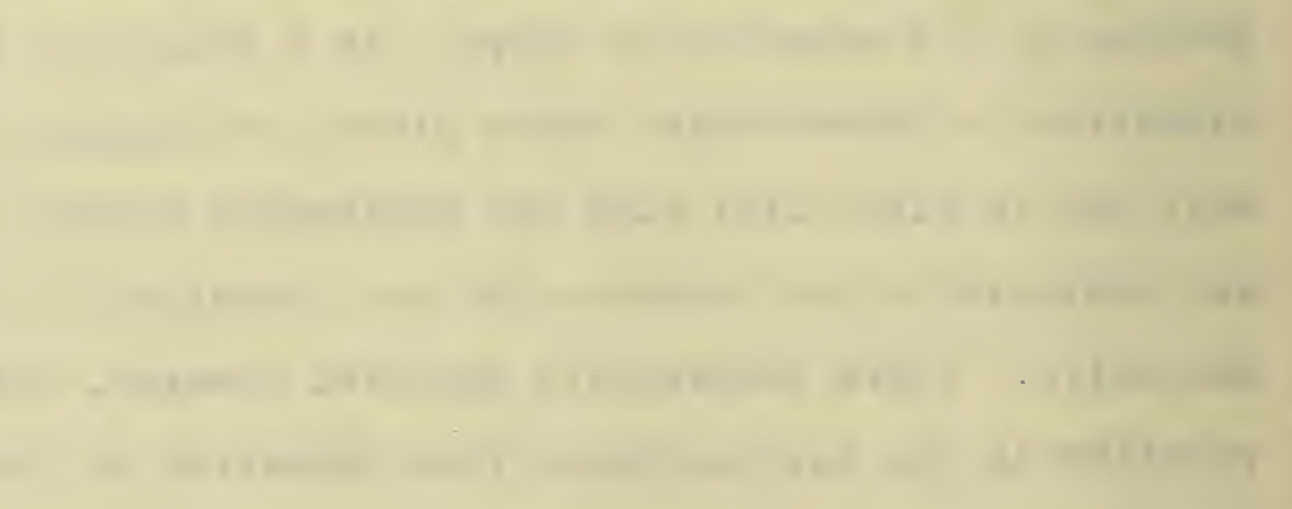
10

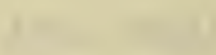


B. Chemistry of Starch Decomposition by Enzymes.

The size and chenistry of the starch molecule has been the subject of much chemical research since about 1836 when Payen announced the chemical composition to be $\left(\mathrm{C}_{6} \mathrm{H}_{10} \mathrm{O}_{5}\right)_{\mathrm{n}}$ This imperical formula is generally accepted at the present time, but it is very hard to prepare starch entirely free from phosphoric acid. It is possible that this mineral (acid) is in union with the starch molecule. Certain facts about starch indicate a high degree of complexity which probably approaches that of the proteins. Among these facts are its highly colloldal nature, the ease with which it can be removed from its solutions by forcing through earthenware, and the small influence which it exerts upon the freezing point of its solvent. "The $\left(\mathrm{C}_{6} \mathrm{H}_{10} \mathrm{O}_{5}\right)_{n}$ structure indicates that starch is an anhydride condensation product of glucose or maltose:

"The chemical process of hydrolysis of starch presumably takes place in several phases, in which the dextrins formed as intermediate products are broken down. Amylase may consequently be composed of several enzymes."

The close relationship between enzymes and their substrate indicate that enzymes enter into a chemical combination with the molecules on which they work. Enzymes also enter into combination with dissociation products. Investigations on diastase indicate that enzymes are made up of two parts, a combination of a colloid with an active principle. The colloid is generally related chemically with the substance on which the enzyme acts (substrate). So long as the enzyme is combined with its carrier it remains inactive, but is broken away by slight changes in reaction. 

Tebb (1894), Brown, Morris Röhmann (1894), Hamburger (1895), and Beijerinch (1895) detected in the mixtures of starch saccharifying enzymes, one that transforins starch to maltose, and another that breaks down maltose to glucose. Wijsman (1890) assumed that the reactions, starch to dextrin and dextrin to maltose, were brought about by separate enzymes, and more recently Ascoli and Bonfanti (1904) considered several enzymes as bringing about the change. Although diastase is usually considered as one enzyme, it might more properly be considered as consisting of two classes of enzymes, one which hydrolyzes the starch to soluble starch, dextrins and maltose (amylase), and the other which hydrolyzes the maltose into dextrose (maltose). Brown and Morris (1893) stated that at least two enzymes showing different blological relations, diastase of translocation, and diastase of secretion, exist. Later, Maquenne explained saccharification from a chemical point of view. In this explanation it must be kept in mind that starch consists of $80-85 \%$ amylose and $15-20 \%$ amylopectin.

Amylose is rapidly dissolved when starch is treated with bolling water for a few minutes, gives a blue color with Iodine, and forms no starch paste. It is readily attacked and dissolved by amylase whereas amylopectin is very slowly acted on by this enzyme. "In the saccharification of pure amylose, maltose alone is formed". Amylose is the last of a series of condensation products increasingly soluble in water, the lower members of which are largely contained in soluble starch. Samec (1916) states that the term "soluble starch" is indefinite and does not adequateIy define the substance. He also states that in some cases the size of the molecule was reduced, but in others the molecule was 

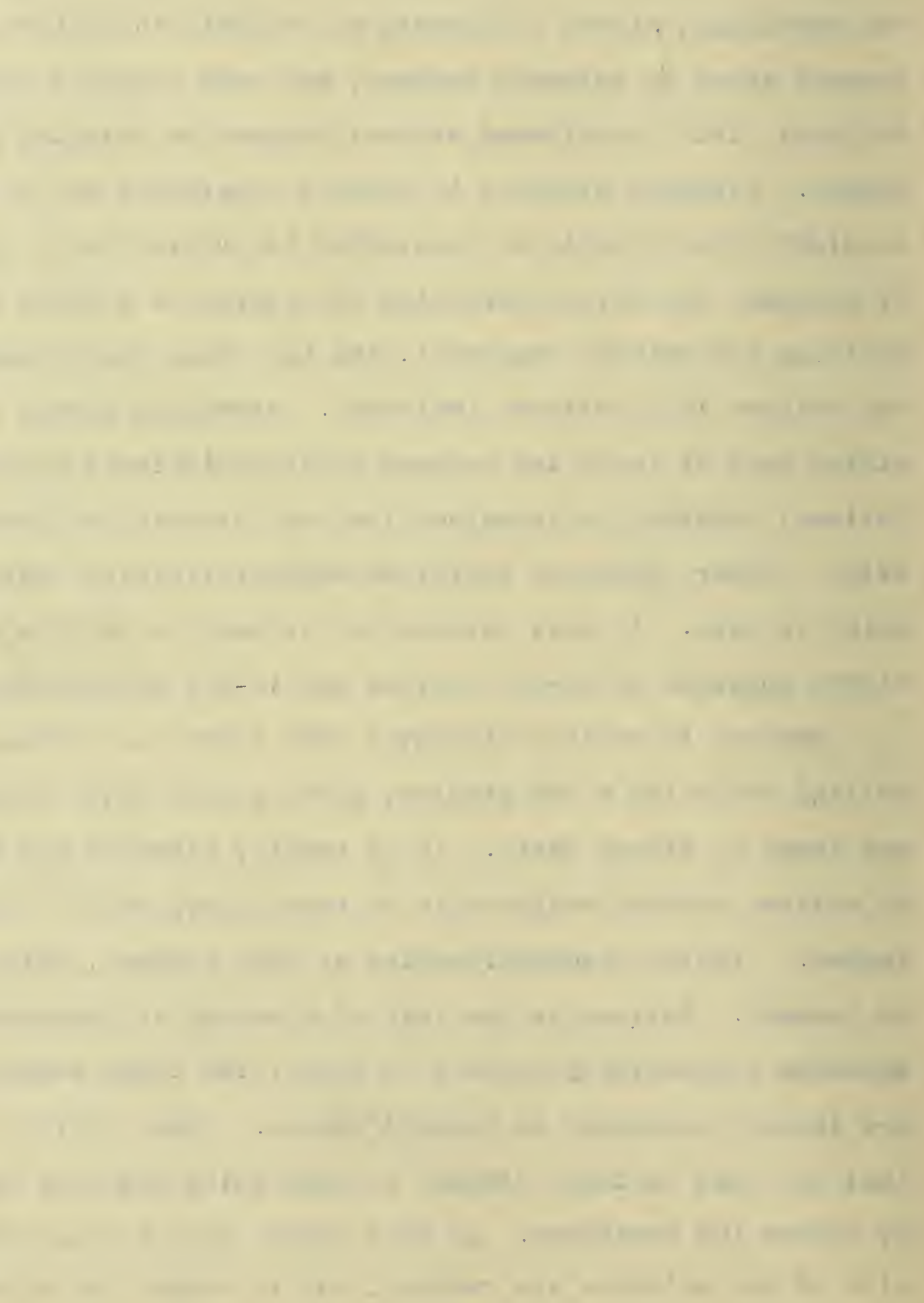
not broken down, and that most forms did not contain phosphorous. Amylopectin is a gelatinous substance, purplish red with Iodine, insoluble in water and alkalies, and on hydrolysis, gives dextrin as well as maltose. It is probable that the enzyme amylopectinase and not amylase saccharifies amylopectin (starch paste) with ease. The "gelatinazation" of starch caused by hot water probably results from the simultaneous solution of amylose and the swelling of amylopectin.

of these two substances resulting from the breaking down of starch, amylopectin contains all of the phosphorous from the starch molecule, while the amylose contains only a slight trace. The phosphorous pentoxide content of starch according to Samec decreases with the viscosity of starch, but is not broken down by diastase. The diastases of plants and animals must contain both diastatic enzymes. Starch decomposition by enzymes is a hydroIytic process and may be represented by the equation: $2\left(\mathrm{C}_{6} \mathrm{H}_{10} \mathrm{O}_{5}\right)_{n}+\left(\mathrm{NH}_{2} \mathrm{O}\right)=\mathrm{NC}_{12} \mathrm{H}_{22} \mathrm{O}_{11}$. This maltose formed is acted upon by the enzyme maltose giving dextrose. $\mathrm{C}_{12} \mathrm{H}_{22} \mathrm{O}_{11}+\mathrm{H}_{2} \mathrm{O}+$ maltose $=2 \mathrm{C}_{6} \mathrm{H}_{12} \mathrm{O}_{6}+$ maltose. Then alcoholase, a zymase, may act upon the dextrose giving alcohol and carbon dioxide. Experiments by different authors regarding the hydrolysis curves do not agree. A differentiation may be made, in the action of diastasic enzymes upon starch, between the amylolytic (amyloclastic, liquefying) and the saccharogenic power.

A history of the study of the starch molecule shows variation as to the size of the molecule. In 1860 Musculus noted that it was difficult to completely hydrolyze starch to maltose by means 

of malt and later (1878) decided that starch must be a polysaccharide with a molecular size of $\left(\mathrm{C}_{12} \mathrm{H}_{20} \mathrm{O}_{6}\right)$. Herzfeld (1879) pointed out the fact that starch hydrolysis progressed through a series of dextrins of diminishing complexity i. 4. starch $=$ soluble starch $=$ erythrodextrin $=$ achroodextrin $=$ malto dextrin $=$ maltase. To malto dextrin, he gave the formula $\mathrm{C}_{18} \mathrm{H}_{36} \mathrm{O}_{16}$. Brown and Heron (1879) concluded that the starch molecule must be at least five times the size of the residual dextrin and proposed $\left(\mathrm{C}_{12} \mathrm{H}_{20} 0_{10}\right)_{10}$ as the formula for starch, and $\left(\mathrm{C}_{12} \mathrm{H}_{20} \mathrm{O}_{10}\right)_{2}$ as that for the simplest dextrin molecule. In 1855 Brown and Norris reported that dextrin was always present as one of the hydrolytic products of starch. To starch they gave the formula $5\left(\mathrm{C}_{12} \mathrm{H}_{20} \mathrm{O}_{10}\right)_{3}$. Upon hydrolysis an amylin group $\left(\mathrm{C}_{12} \mathrm{H}_{20} \mathrm{O}_{10}\right)_{3}$ was thought to split off as maltodextrin and this in turn to maltose, leaving the four other amylin groups as a more complex dextrin. Lintner and Duell (1893) claimed that in the hydrolysis of starch the complex starch molecule was split. first into amylodextrin (soluble starch) $\left(\mathrm{C}_{12} \mathrm{H}_{20^{\circ}} \mathrm{O}_{10}\right)_{54}$ then into three molecules of erythrodextrin $\left(\mathrm{C}_{12} \mathrm{H}_{20} \mathrm{O}_{18} \mathrm{H}_{20}\right.$ which in turn split into three molecules of achroodextrin $\left(\mathrm{C}_{12} \mathrm{H}_{20} \mathrm{O}_{10}\right)_{6} \mathrm{H}_{20}$, and then into isomaltose, the isomaltose changing to maltose. In 1899 Brown and Millar discovered a reducing dextrin to which they gave the formula $39\left(\mathrm{C}_{6} \mathrm{H}_{10} \mathrm{O}_{5}\right)+$ $\left(\mathrm{C}_{6} \mathrm{H}_{12} \mathrm{O}_{6}\right)$ or $40\left(\mathrm{C}_{6} \mathrm{H}_{10} \mathrm{O}_{5}\right)+\mathrm{H}_{2} \mathrm{O}$. "It might be made up of the condensation of forty glucose molecules with the elimination of 39 molecules of water, in accordance with the appended structural formulas". 


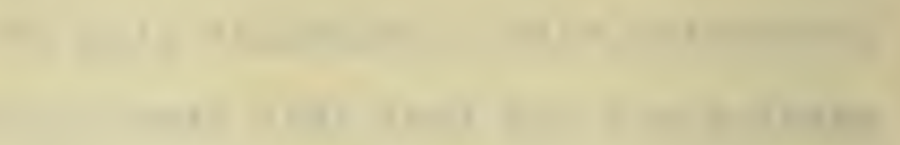

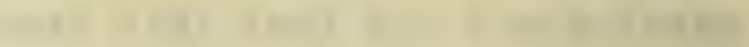

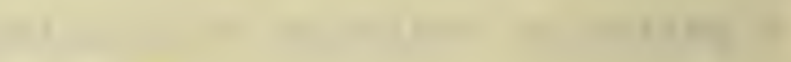

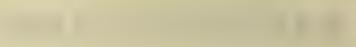

4.

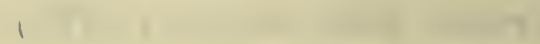

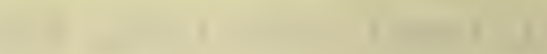

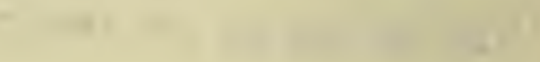

.

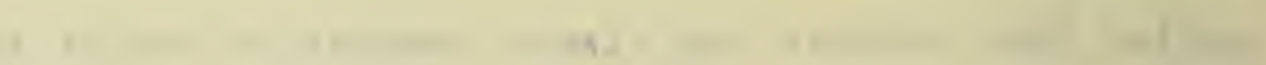

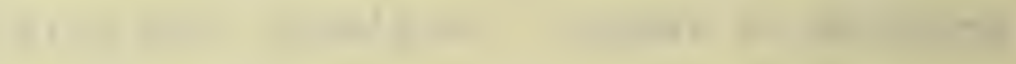

12000

$\sqrt{20}$

(2)

r

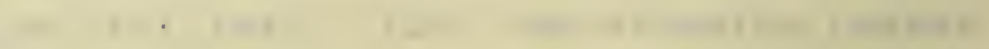

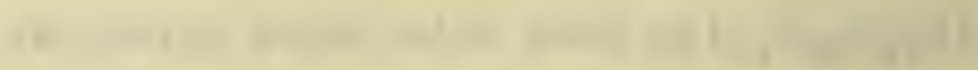

$+4$

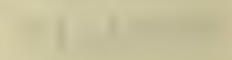

$-$

and 


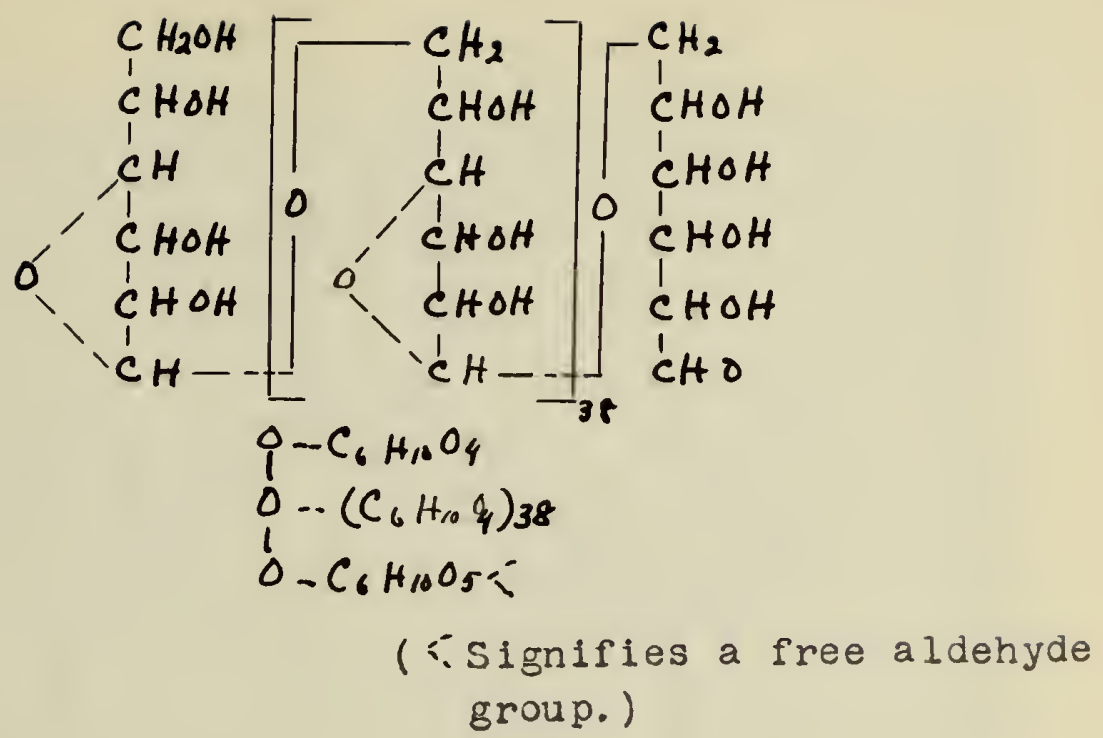

These investigators state that the simplest way to express the constitutional form is to consider it made up of the eighty residues of maltan and forty dextran groups linked in a ring form by means of oxygen atoms. According to this the starch molecule may be represented by their proposed configuration. 



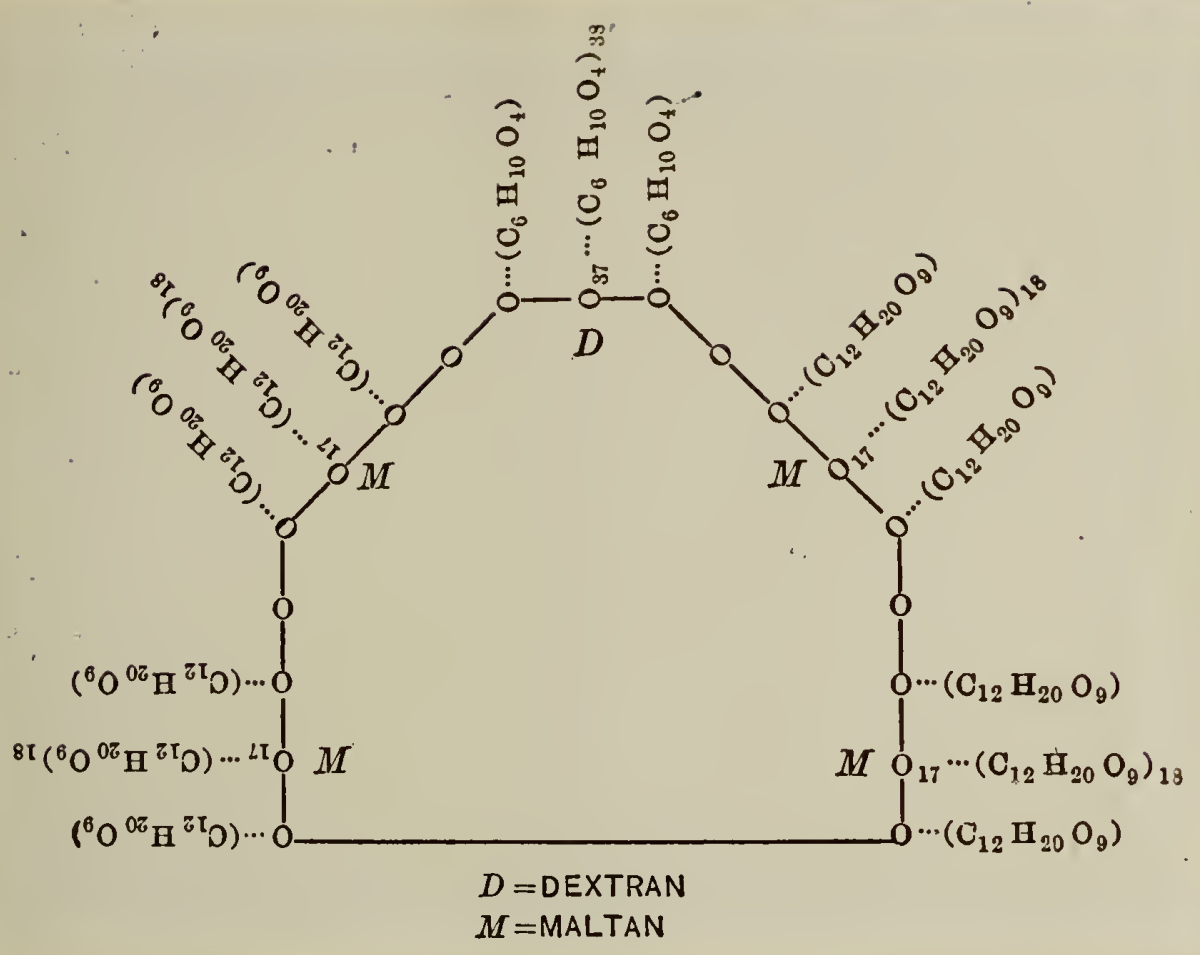

Brown and Milier's Proposed Configuration of the Starch Molecule. 

Ling (1910) attacked this structure and regarded the starch molecule as $\left(\mathrm{C}_{6} \mathrm{H}_{10} \mathrm{O}_{5}\right) \mathrm{n}-\left(\mathrm{n}-1 \mathrm{H}_{2} \mathrm{O}\right)$ inasmuch 23 he considered carbohydrates to be derived from monoses by a series of condensations with the elimination of water. Johnson (1898) as a result of hypothesis proposed a formula based upon the fact that starch must be a multiple of $\left(\mathrm{C}_{6} \mathrm{H}_{10} \mathrm{O}_{5}\right)_{4}$, these groups belng arranged as follows. 



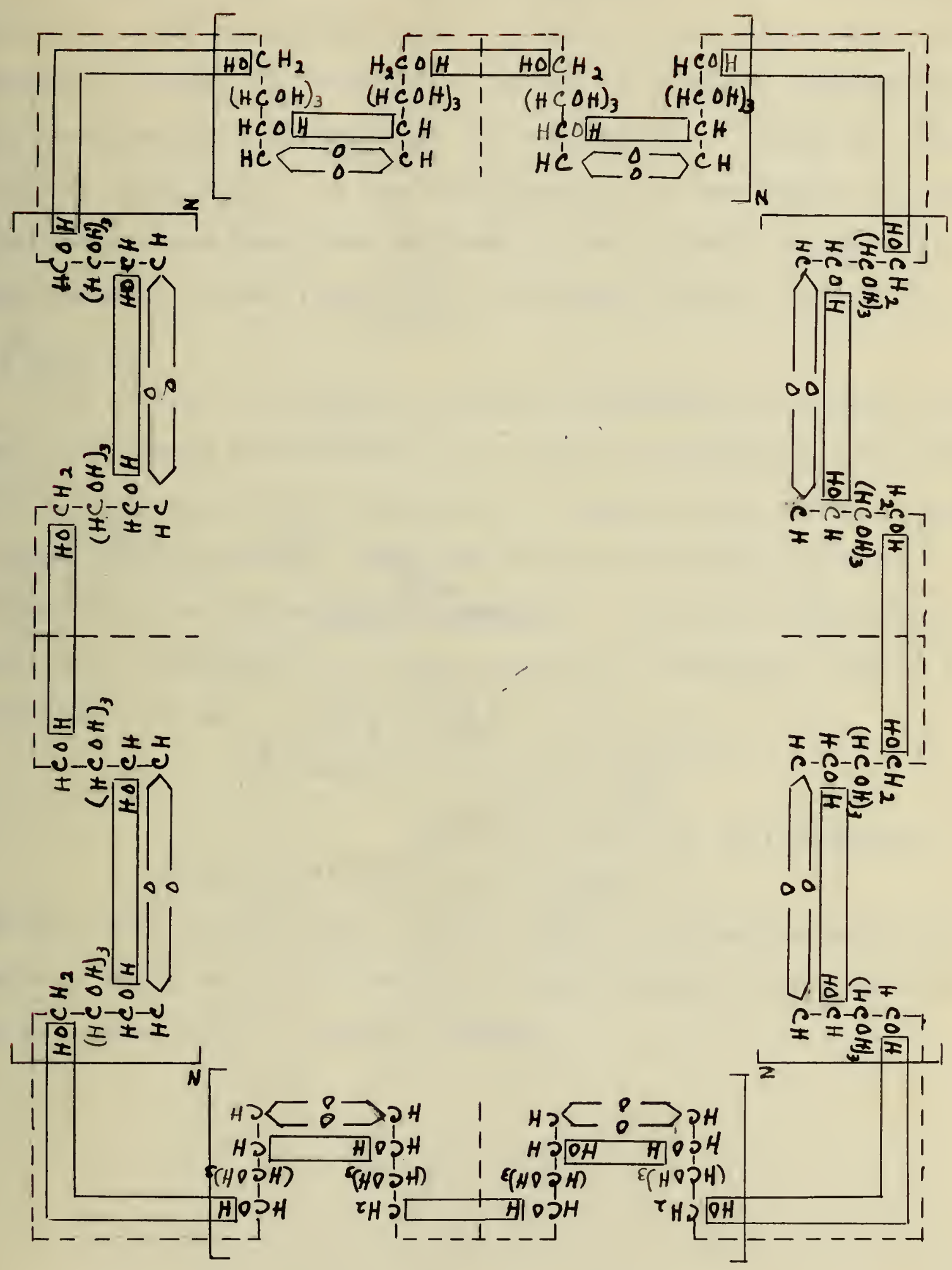




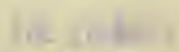

of $T^{\mathrm{T}}$

Give'rn ral'
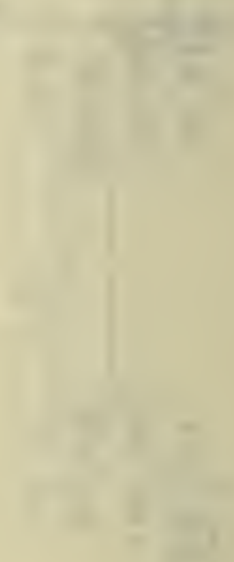
Synkiewski (1902) studied the hydrolysis of starch by malt infusions. His hypothesis rests entirely on two dextrins: protodextrir. I, formed by hydrolyzing starch at ordinary temperature, and protodextrin II, formed by the hydrolysis of starch at $78^{\circ} \mathrm{C}$. He gives $\left(\mathrm{C}_{6} \mathrm{H}_{10} \mathrm{O}_{5}\right)_{36}$ as the configuration of the starch molecule. Other structures have been proposed by $\mathrm{Hale}(1902)\left(\mathrm{C}_{6} \mathrm{H}_{10} \mathrm{O}_{5}\right)_{18}$; Kladiaschwill (1904) $\left(\mathrm{C}_{7} \mathrm{H}_{10} \mathrm{O}_{6}\right)_{6}$; and Skraup (1905) $\left(\mathrm{C}_{6} \mathrm{H}_{10} \mathrm{O}_{5}\right)_{46}$ to $\left(\mathrm{C}_{6} \mathrm{H}_{10} \mathrm{O}_{5}\right)_{50}$

The theory of the great molecular complexity of starch has been more firmly established by the work of Pringsheim (1912-15) who by fermentation and hydrolysis of starch under different conditions obtained several dextrins which were tetra-and hexapolymers of the simple dextrin molecule. From his experimental results he concluded that these dextrins or "amylases" have a ring structure such as

$$
0=\begin{aligned}
& \mathrm{CH}-[\mathrm{CH}(\mathrm{OH})]_{2} \mathrm{CH} \cdot \mathrm{CH}(\mathrm{OH}) \cdot \mathrm{CH}_{2}>0 \text { or } \\
& \left.\mathrm{CH}_{2} \cdot \mathrm{CH}(\mathrm{OH}) \cdot \mathrm{CH}_{\mathrm{L}} \mathrm{C} \mathrm{CH}(\mathrm{OH})\right]_{6} \mathrm{CH}
\end{aligned}
$$

$$
\mathrm{HoCH} \cdot \mathrm{CH}(\mathrm{OH}) \underbrace{\mathrm{O} \cdot \mathrm{CH} \cdot \mathrm{CH}(\mathrm{OH}) \mathrm{CH}}_{[\mathrm{CH}}
$$

and that they indicate that starch 1tself, and the non-reducing dextrins which are not fermented by heast contain the ring which can be opened only be special ferments. 
,

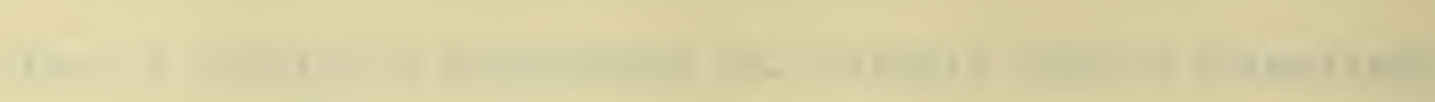

-

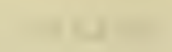

$+1$

$1=$

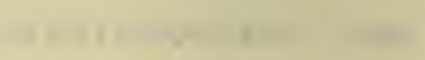

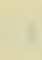

1

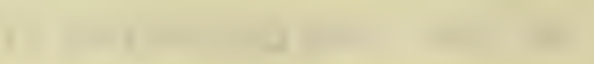

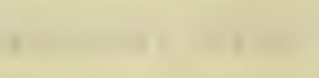

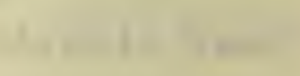

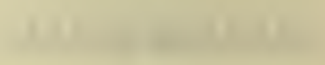

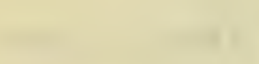

$-$

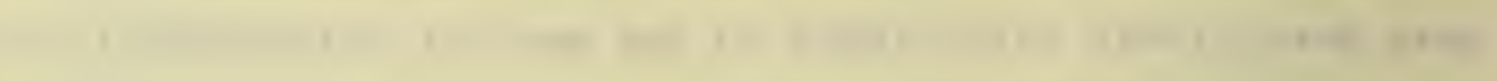
$-$

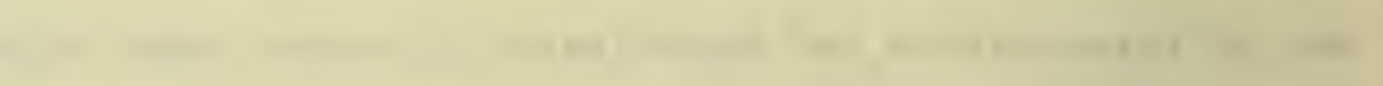
1)

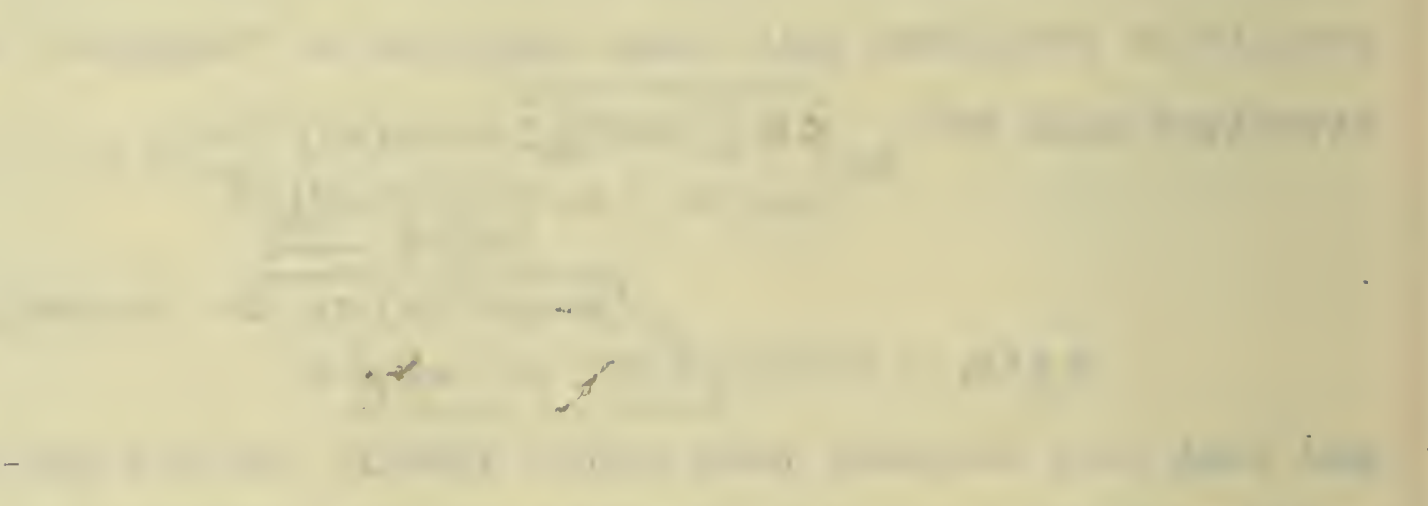

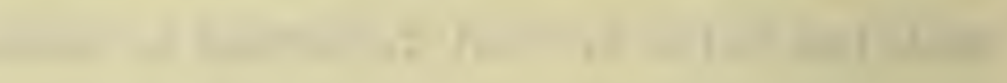

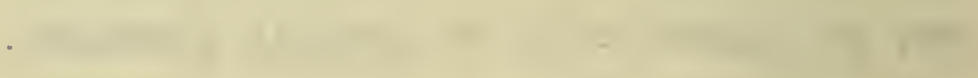


The Diastasic Enzymes.

Diastase or amylase, one of the most common eyzmes in nature, is present in all green plants, especially in germinating seeds, in shoots and leaves and other portions where starch is stored. In very young plants the germ is surrounded by storage substances used for food in growth. Among these substances is starch which is digested by enzymes, secreted by the growing germ, and which act outside ofthe protoplasm. It is said that the enzyme diastase hydrolyzes starch from grains more readily than starch from the legumes.

This type of enzyme is also found in the secretions of animals as in saliva, pancreatic juice, and in the liver. Here these enzymes play an important rôle in digestion. Muscles also are rich in thisenzyme which attacks glycogen.

Amylases or diastases include all those enzymes which break down starch and glycogen formirg maltose. Euler and Pope (1912) state that very 1 ittle that is definite can be asserted with regard to the individuality of the diastases (amylases).

Of these enzymes, two forms are distingulshed "according to the type of corrosion of the starch grain": diastase of translocation which occurs in plants, especialiy in the chlorenclyme of leaves and which corrodes the grains evenly: and diastase of secretion which occurs especially in the seeds and corrodes the grains unevenly. Then dialyzed in spring water, the dissolved diastases are separated into two principal groups, the saccharifyIng diastases which diffuse through a membrane, and the I1quifying ones. which remain. 


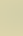

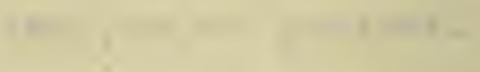

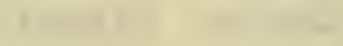

1

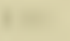

+ $-1$

(20)

,

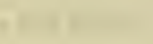

It 10

1

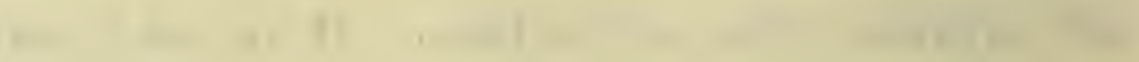

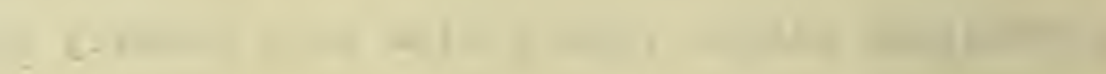

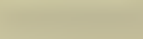

1

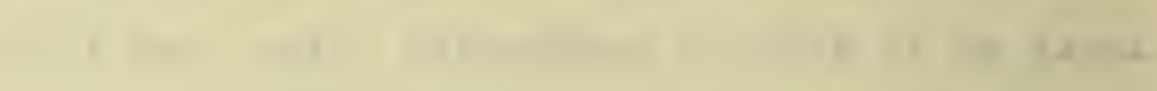

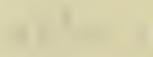

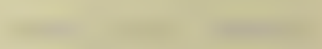

.

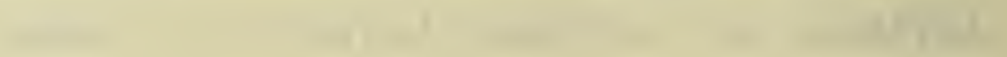

athand

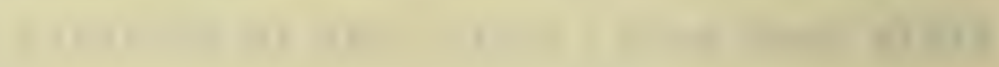

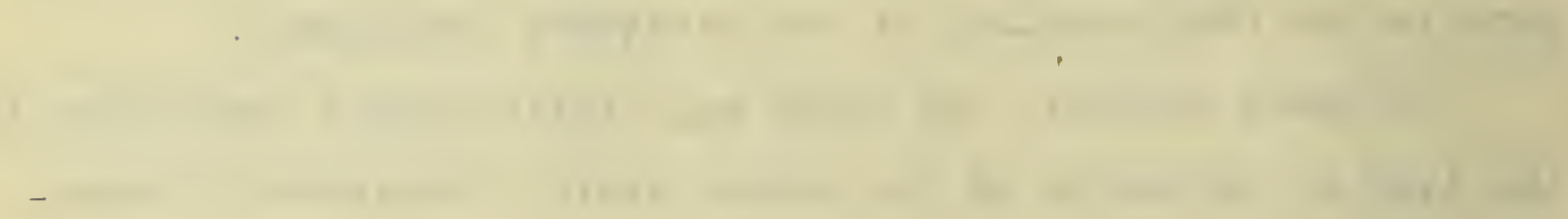

,

1.

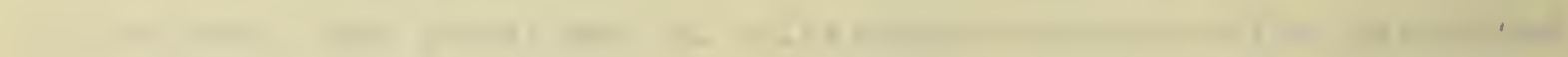
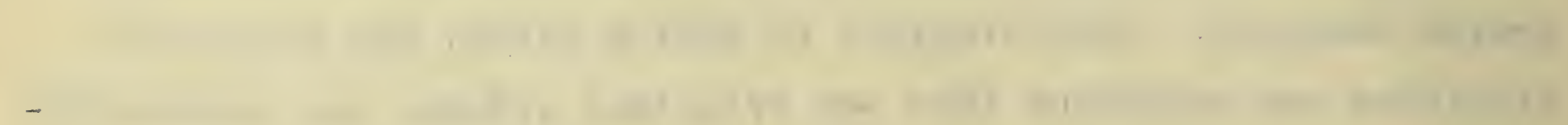

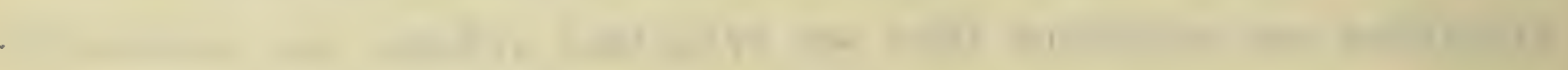


In the simple organisms, as bacteria, as well as in the higher plants, the secretion of diastase has a direct bearing upon the question of nutrition of the organism. Brown and Morris (1890) state that starvation is a stimulus to this secretion; Wortmann (1882) and Lauder, Brunton and MacFadyen (1889) that diastases are secreted when starch is the only food. With animals it is said to be largely dependent upon the nervous impulses. "Amylase can assume at the same temperature two distinct forms: a soluble form immediately saccharified and colored by Iodine, and a solid form which resists malt and gives no reaction with Iodine. The latter is perhaps a polymeric form of the first." As a result of the study by Koch (1916), several conclusions were drawn:

That diastasic eyzmes are secreted by bacteria quantitatively. That there is a considerable variation in their activity on different media.

That the enzyme activity is variable from dayato day.

That there is no direct correlation between hydrolytic enzyme secretion and protein decomposition by bacteria, and

That enzyme activity of different species varies greatly. The action of diastase is in many respects similar to that produced by acids acting on carbohyurates. Various diastases differ considerably among themselves as to nature and sensitiveness towards reagents.

The greater or less sensitiveness of diastases to the action of antiseptics and to those substances paralyzing the vital activity can be utilized to exclude the acilvity of microörganisms during diastasic action. Cellular activity of a cell may be de- 

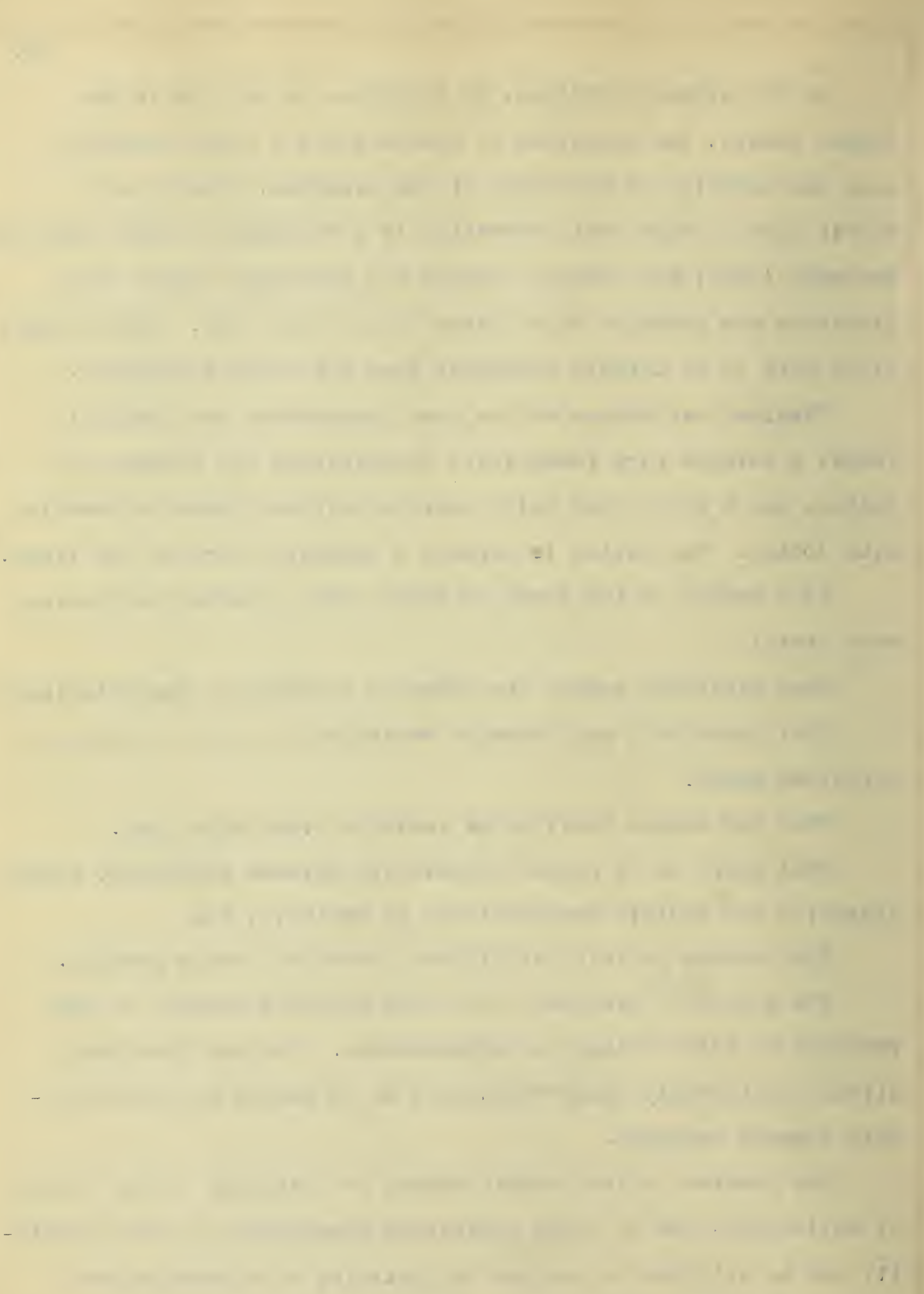

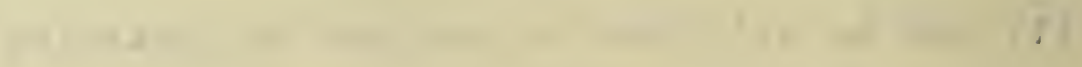

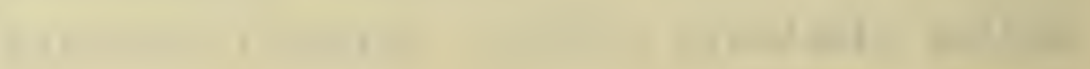


stroyed, yet it may secrete diastase. Different diastases may be characterized by their optimum temperature. Payen found a general property of enzymes and a general means of isolation in their property of being precipitated from solution by alcohol. (Some diastases dissolve easily while others require a larger anount of water).

Chrzosoz (1908) showed that both the saccharifying and liquifying action of the diastases are often parallel.

"Mork with different diastases and different starches under varying conditions tenc to show that soluble starches are not a.l attacked to the same degree by the same diastases at the same temperature."

"Lang (i911) has shown that different starches of different origins react differently to pancreatic diastase.

Ehrich (1916) states that raw and gelatinized potato starch Is more readily saccharifled than barley starch, and the latter more easily than gelatinized malt starch.

In work on hydrolysis curves, it has been found that the initial speed of conversion for a constant amount of enzyme was the same for different concentrations of starch, and that the reaction diminished the more rapidly, the smaller the initial concentration of the starch.

It has been found that certain acids and salts have an influence upon the activity of diastases. Sherman and Thomas (1915) found that "weak acids (acetic, propionic, phosphoric) strong acids (hydrochloric, nitric, sulphuric) and acid phosphates 
.

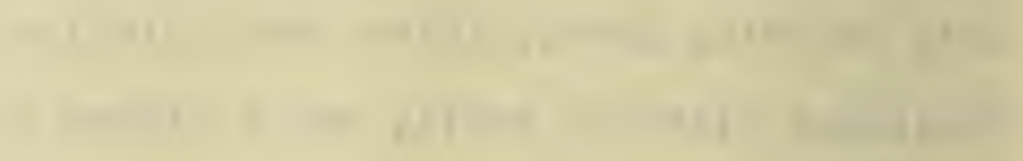

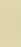

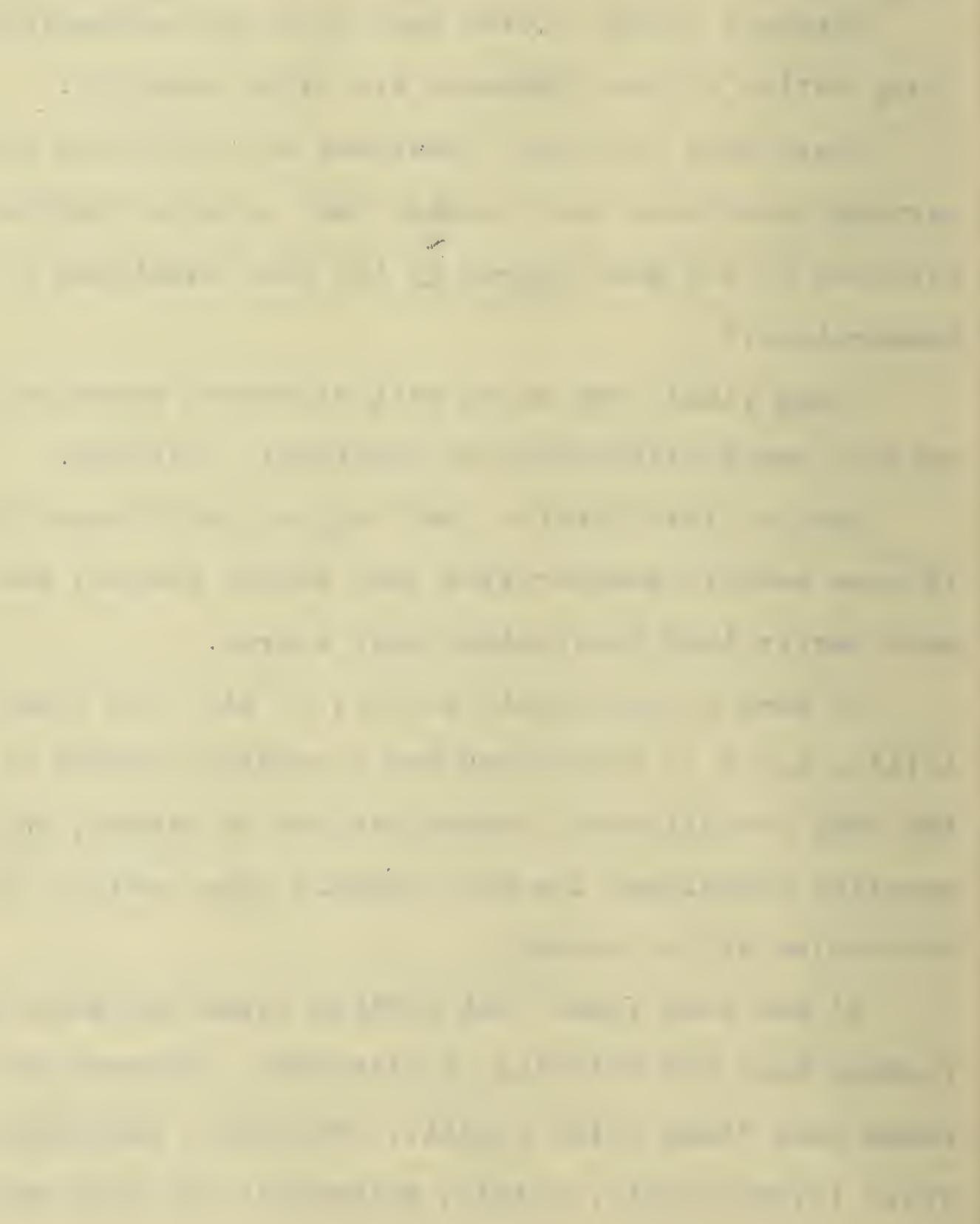


(sodium and potassium) produced optimum activation of malt diastase in concentrations corresponding to the same actual acidity, ${ }^{p_{H}}=$ 4.2 deternined electrometrically.

According to Iintner and others, the action of malt diastase is accelerated only by very small quantities of weak acids. A concentration of acid as low as $0.001 \%$ of Hydrochloric causes retardation. With pancreatic diastase, rather high concentrations of Hydrogen ions (about $0.001 \mathrm{~N}$ ) are necessary for the activity to reach its maximum.

Pancreatic, malt, and aspergillus oryzae amylases react favorably in the presence of salt and phosphate. Mith these, considerable dextrin remained, indicating that dextrin, maltose, and glucose may not be the only products of the action of amylases on soluble starch. The amylase of aspergillus oryzae exerts its maximum activity both amyloclastic and saccharogenic, in a very slightly acid medium. Acid phosphates accelerate and alkaline phosphates retard the action. Neutral electrolytes (sodium chloride, potassium chloride) have no measurable effect on the saccharogenic action, but increase the amyloclastic action of commercial taka-diastase. "When saccharification and fermentation are both conducted simultaneously, the addition of small quantities of calcium salts help to prevent any refractony starch particles from escaping dissolution, while its retarding influence on saccharification is of no serious importance."

Sherman and Wafker (1917) found that the action of malt amylase was increased when the electrolyte (hydrochloric, phosphoric acid, potassium, di-hydrogen ion, $\left.C_{11} 10-4.4\right)$, also that when the 

concentration of the enzyme was increased, the effect of the electrolyte was decreased.

Sherman, Thomas and Baldwin (1919) conflrmed earlier findings on the optimum hydrochloric ion concentration for malt amylases by using the Clark cell and rocking electrodo.

They found that pancreatic amylase is active between $\mathrm{P}_{\mathrm{H} 4}$ \& 10 with an optimum at 7 ; malt amylase is active betweon $\mathrm{P}_{\mathrm{H}} 2.5$ \& 9 with an optimum at $4.4-4.5$; and amylases of aspergillus oryzae between $\mathrm{P}_{\mathrm{H}}{ }^{2.6}-8.0$ with an optimum at about 4.8. Also that the influence of the concentration of the electrolyte, as distinguished from the concentration of the hydrogen ion alone is greatest in the case of pancreatic and least in that of aspergillus oryzae amylase.

Adler (1916) found that malt diastase is active at $20^{\circ} \mathrm{C}$ at a hydrogen ion concentration of $\mathrm{P}_{\mathrm{H}} 4.9$ as determined by the reduction of Fehling's solution and color reduction of Iodine solution.

Contrary to the cholrides, nitrates, sulphates, and phosphates of Sodium and Potassium, the bromides show an inhibitory effect on the activity of malt anylase when present in small amounts and an activating effect when their concentration is increased.

Potassium permanganate, hydrogen peroxide and lodine in very small concentrations inhibit the action of diastase. Ordinary formaldehyde accelerates the action slightly, but this acceleration is due to the formic acid it contains. If neutralized, it has a slight ly inhibitory effect.

In the action of malt amylase upon soluble starch, there is no "region of linear relationship" in which the yield of reducing sugar is directly proportional to the time. 



\section{EXPERIMENTAL.}

This investigation had its origin in an attempt to secure a better method for determining the diastasic action of microörgan1sms, than those which are now being used by microbiologists, and also to better understand the conditions under which those methods now in use yield most reliable results. Such a study, on account of the multiplicity of governing conditions, soon becomes rather intricate and it is not easy to select combinations which yield the best results. In order to preserve coördination among the experiments carried out and to keep the data collected in easily accessible form the work has been divided into separate parts as follows:

A. Effect of different amounts of starch on the action of diastasic enzymes on the starch agar plates.

B. Effect of concentrated agar solutions on the action of the diastasic enzymes on the starch agar plate.

C. Effect of the length of incubation period on the action of diastasic enzymes on the starch agar plate.

D. Effect of different starches in the action of diastasic enzymes on the starch agar plate.

E. Study of diastasic action in synthetic media.

F. Study of different methods used in determining diastasic action.

G. Study of varying the amount of peptone on the diastasic action of bacteria, using the dot and streak inoculation. A. In order to determine the effect of different amounts of starch on the action of diastasic enzymes in starch agar, different percentages of potato starch were added to agar according to 

the following table:

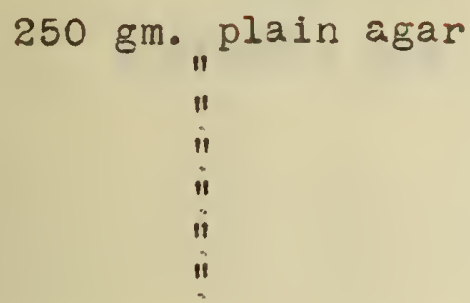

.50 gms. soluble starch

1.25

2.50

3.75

5.00

7.50

10.00

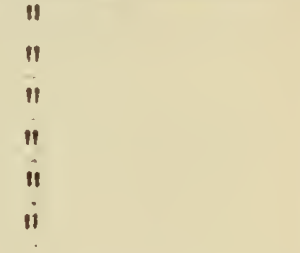

The starch agar was placed into tubes, $10 \mathrm{c.c}$. to a tube, sterlized, poured into sterile Fetrie dishes, allowed to harden, cooled and streaked with the test organisms, B. mesentericus, B. vulgatus, B. cereus, making one streak across the center of the plate. The plates wore then inverted, incubated at $37^{\circ} \mathrm{C}$ for 3 to 4 days, flooded with Iodine, and the diastasic action determined In millimeters by the width of zone of liquefaction. Before adding the Iodine, the width of growth of the organism was measured in millimeters, and after flooding, the action was determined by the same scale. The averages of action are given on Table Ia.

After having determined the diastasic action of the test organisms on percentages of starch from.2 to 4.0 , the same procedure was used to determine the action on smaller percentages of starch a.s follows: $0.1, .05, .025, .020, .015, .010$ per cents the results of which are given in Table Ib.

With the lower percentages $(.025, .20, .015$, and .010 per cents) the amount of starch present was so small that the diastasic action with Iodine was hard to distinguish. A gradual deepening in color resulted with the increasing percentages of starch. This shows that there was not enough starch present in the four lowest. percentages to give satisfactory results. With all of the percentages used, it was found that better results were obtained by allowing the agar plates to cool and harden for some time, perhaps 
.

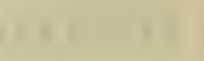
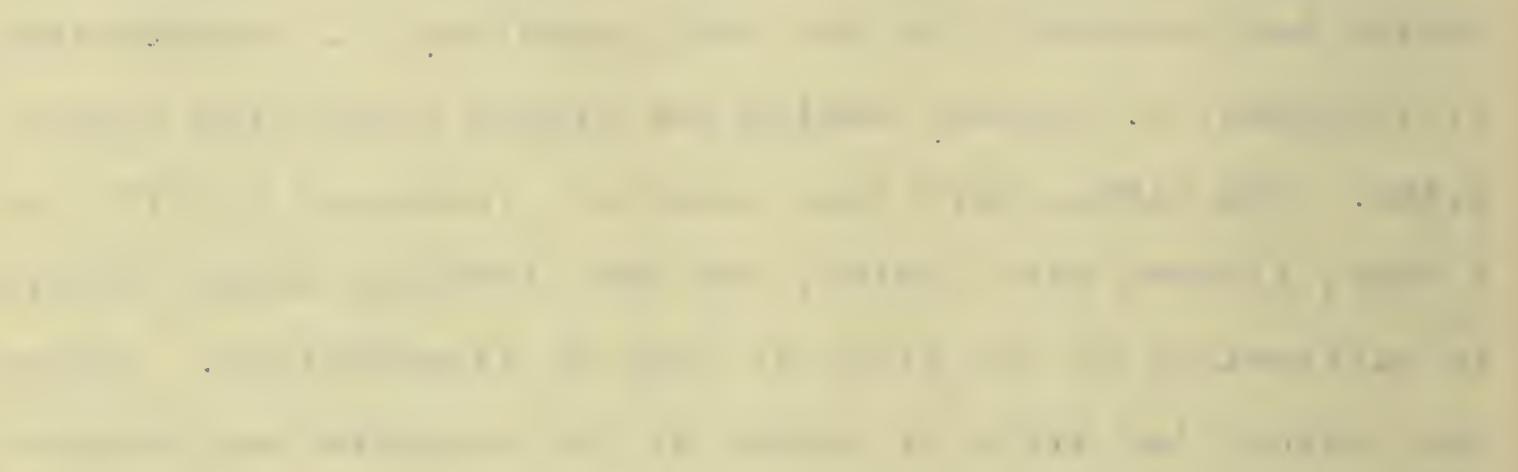

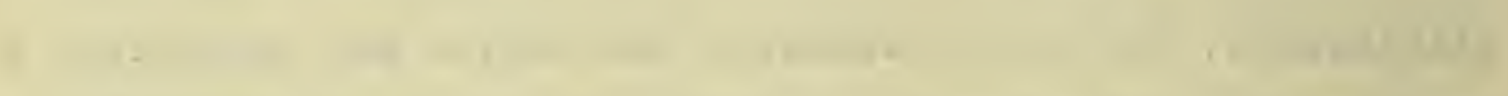

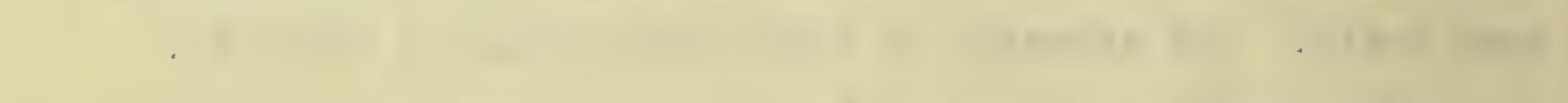

$-$
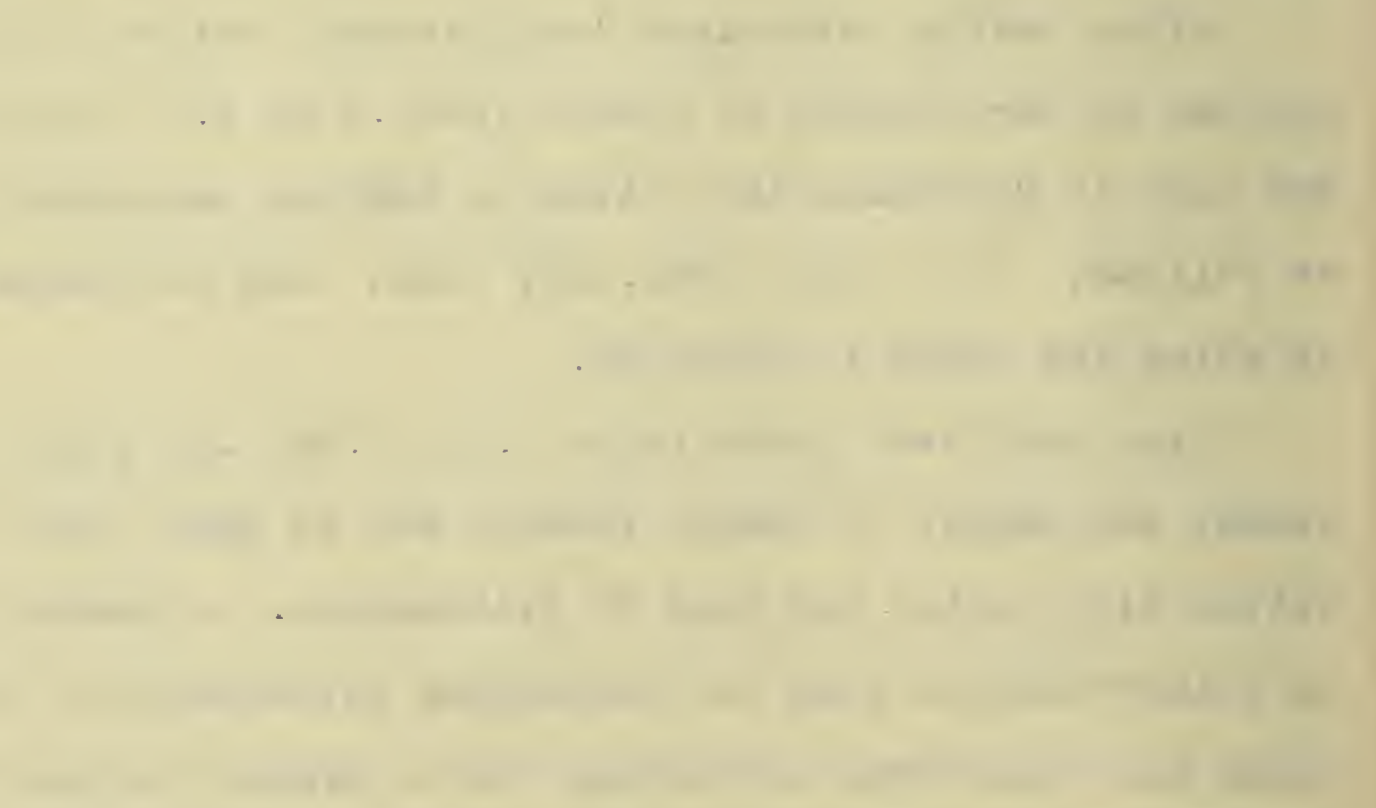

(1)

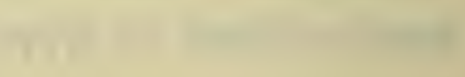

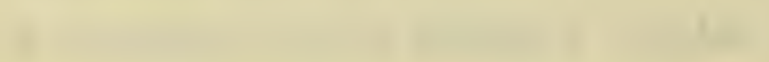

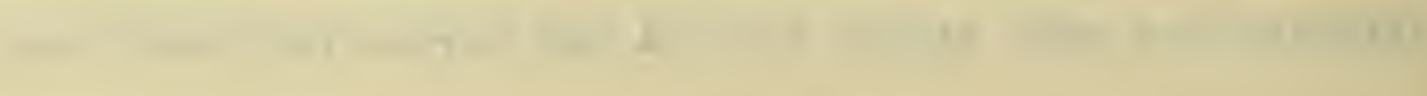


Table I2. Diastasic Action with $0.2 \%-4.0 \%$ Starch Inclusive and $11 / 2 \%$ Agar.

\begin{tabular}{||l|c|c|c|c|c|c|c||}
\hline \multirow{2}{*}{ Organism. } & \multicolumn{7}{|c|}{ Percentages of Starch. } \\
\cline { 2 - 9 } & 4 & 3 & 2 & 1.5 & 1.0 & 0.5 & 0.2 \\
\hline B. mesentericus & $* 41$ & 45 & 50 & 42.5 & 61.5 & 57.5 & 58 \\
\hline B. cereus & 25 & 40 & 51 & & 42.5 & 2.75 qnt ire \\
\hline B. vulgatus & & 160 & 31 & 40 & & 47.5 & 39.5 \\
\hline
\end{tabular}

*Figures indicate width of zone of diastasic action in millimeters. 

Table Ib. Diastasic Action with .01\%-1.0\% Starch Inclusive and $11 / 2 \%$ Agar.

\begin{tabular}{|l|c|c|c|c|c|c|}
\hline \multirow{2}{*}{ Organism. } & \multicolumn{5}{|c|}{ Percentages of Starch. } \\
\cline { 2 - 7 } & 0.1 & .05 & .025 & .02 & .015 & .01 \\
\hline B. mesentericus & $* 70$ & 90 & 60 & 65 & 62.5 & 55 \\
\hline B. cereus & 3.3 & 37 & 90 & 40 & 42.5 & 42.5 \\
\hline B. vulgatus & 50 & 42.5 & 25 & 20 & 45 & 45 \\
\hline
\end{tabular}

*Figures indicate width of zone of diastasic action in millimeters. 


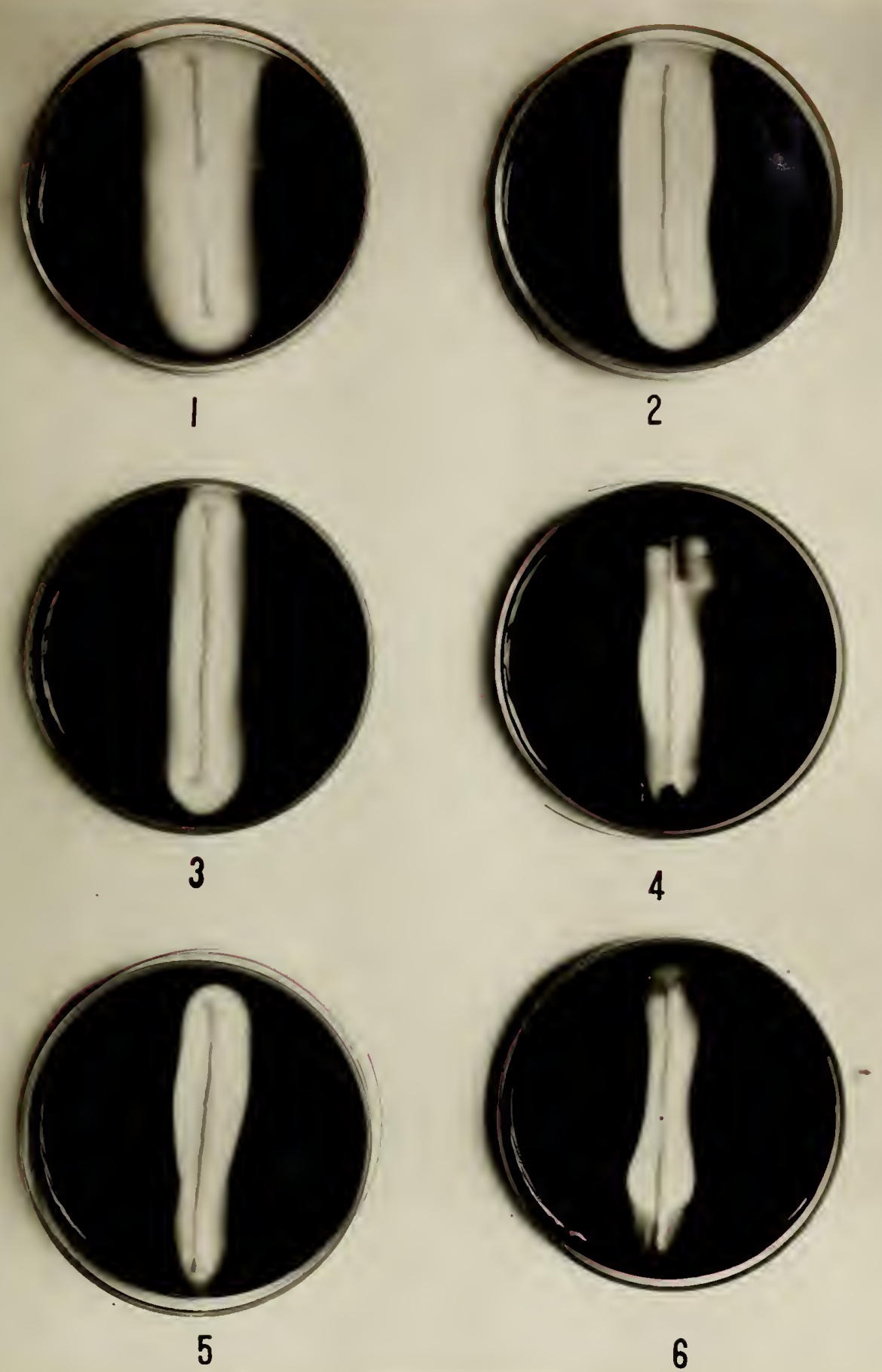

Fig. 1. Shawing the Effect of Different Amounts of Starch on the Diastasic Action of B. vulgatus on 1 1/2\% Agar After 4 Days Incubation at $37^{\circ} \mathrm{C}$.
$1=0.1 \%$
$2=1.0 \%$
$3=1.5 \%$
$4-2.0 \%$
$5-3.0 \%$
$6-4.0 \%$ 

over night, before streaking. When this was done the streaking was more uniforn, since the starch agar was firmer and the wire did not, break through as it tended to do when the plates were freshly poured. It was also found that spreaders, when present, had usually developed after twenty-four hours. The work so far, showed that the best results were obtained between $2.0 \%$ and . $5 \%$ of starch. Within this range, there was probably the proper concentration of starch to be attacked by the enzymes.

B. The next step was to determine whether a heavier agar might not show a sharper diastasic action since the enzymes would not diffuse so rapidly and their action be limited to a small distance from the line of inoculation. To prove this, $0.5,1.0,1.5$ and 2. 0 per cents of potato starch were added to two and one-half per cent agar.

The same technigue was used except that in working with the heavier agar it was found to be necessary to pour the agar while quite hot, or otherwise it would harden before covering the surface of the Petrie dish. When cooled to the temperature at which $11 / 2 \%$ agar could be cooled before pouring, the $21 / 2 \%$ agar became too thick to give satisfactory results. By pouring the agar hot, leaving the covers of the dishes tipped for a short time (perhaps 5 minutes) then placing the dishes at $37^{\circ} \mathrm{C}$ with covers tipped for one-half hour, good results were obtained, although in some cases contamination resulted. The firmer agar allowed better inoculations to be made. 


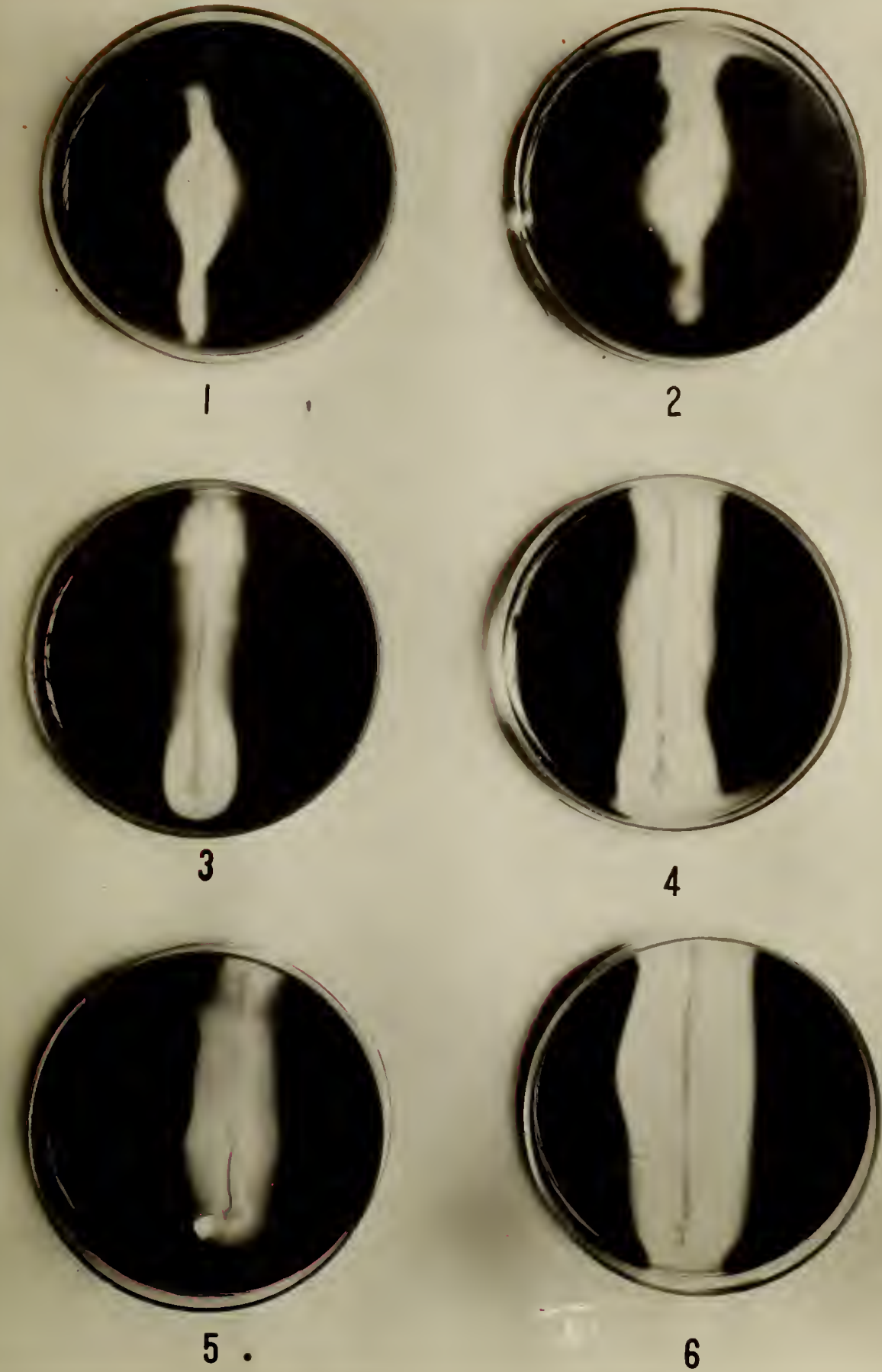

F1g. 2. Showing the Effect of Length of Incubation Period $\left(37^{\circ} \mathrm{C}.\right)$ on Diastasic on $11 / 2 \%$ Agar and $2 \%$ Potato Starch with B. vulgatus.
1- One day.
2- Two days.
3- Three days.
4- Four days.
5- Fivo days.
6- Six days. 

After thus Gisposing of the excess moisture, the plates were streaked with the test organisms, incubated at $37^{\circ} \mathrm{C}$ for $s 1 x$ days and tested, the results of which are shown in Table II.

When these plates were observed the first day, no spreaders had developed a.s they had in 1 1/2\% agar. By the third day, however, a few had aeveloped, but not as many aswith the smaller percertage of agar. On testing with Iodine, a clear cut line of diastasic action resulted. In almost all of these plates a purple color was present at the edge of the clear zone, showing that the more concentrated agar solution had prevented the complete action of the diastasic enzymes. It is probable that the heavier agar prevented the diffusion of the enzymes making it act within narrower limits than with the one and one-half per cent ager. 

Table II. fction in Millimeters on $21 / 2 \%$ Agar with percentages of Starch from $0.5 \%$ to $2 \%$ inclusive.

\begin{tabular}{|c|c|c|c|c|c|c|c|c|}
\hline \multirow[b]{3}{*}{ Organisms. } & \multicolumn{8}{|c|}{ Percentages of Starch. } \\
\hline & \multicolumn{2}{|c|}{2.0} & \multicolumn{2}{|c|}{1.5} & \multicolumn{2}{|c|}{1.0} & \multicolumn{2}{|c|}{0.5} \\
\hline & *Gr. & ${ }^{*} \mathrm{~A}$ & Gr. & $A$ & Gr. & $A$ & Gr. & A \\
\hline B. mesentericus & 48.5 & 52 & 52 & 54 & 56.5 & 57 & 39 & 46.5 \\
\hline B. cereus & 22.5 & 25 & 2.1 .5 & 27 & 18.5 & $22 \cdot 5$ & 17 & 27 \\
\hline B. vulgatus & 12 & 26 & 12 & 26 & 9 & 29 & 9 & 32.5 \\
\hline
\end{tabular}

$*_{\text {Gr. }}=$ Growth in miliimeters.

${ }^{*} \mathrm{~A}=$ The width of clear zone in millimeters. 

C. The value of any test for determing the cultural or marphological characteristics of an organism is somewhat determined by the conditions under which the test has to be usea. Usually, it is desired that a satisfactory test return results in the shortest time with the greatest accuracy. The time element is an important one in this study.

In order to determine this, 1.0 and 2.0 per cent starch in $11 / 2 \%$ agar was used with the test organisms and five series of duplicate plates tested each day for five days. B. arborescens and B. subtilis were here added to the test organisms. The averages of the growths and diastasic action are given in Table III..

On the first day's observation no spreaders or irregular growth had occurred, and the line of diastasic action was clear cut. On the second day's observation some 1rregular growths had taken place. of these two observations, the $1.0 \%$ starch seemed to give the better results, i.e. the line of diastasic action seemed clearer than in the $2.0 \%$ starch. During the last three days more irregular growths resulted, and on the fifth day the $2.0 \%$ gave the better result. In 211 the observations there were dark specks on the clear background for about five millimeters between the clear space and the blue undigested starch. On the later observations this was more so with the $1.0 \%$ than with the $2.0 \%$ starch, but on the lst and 2nd days the $1.0 \%$ starch gave the best results. The amount of starch to be used then seems to depend on the period of incubation used. A low concentration with a long incubation period would probably show complete destruction. 

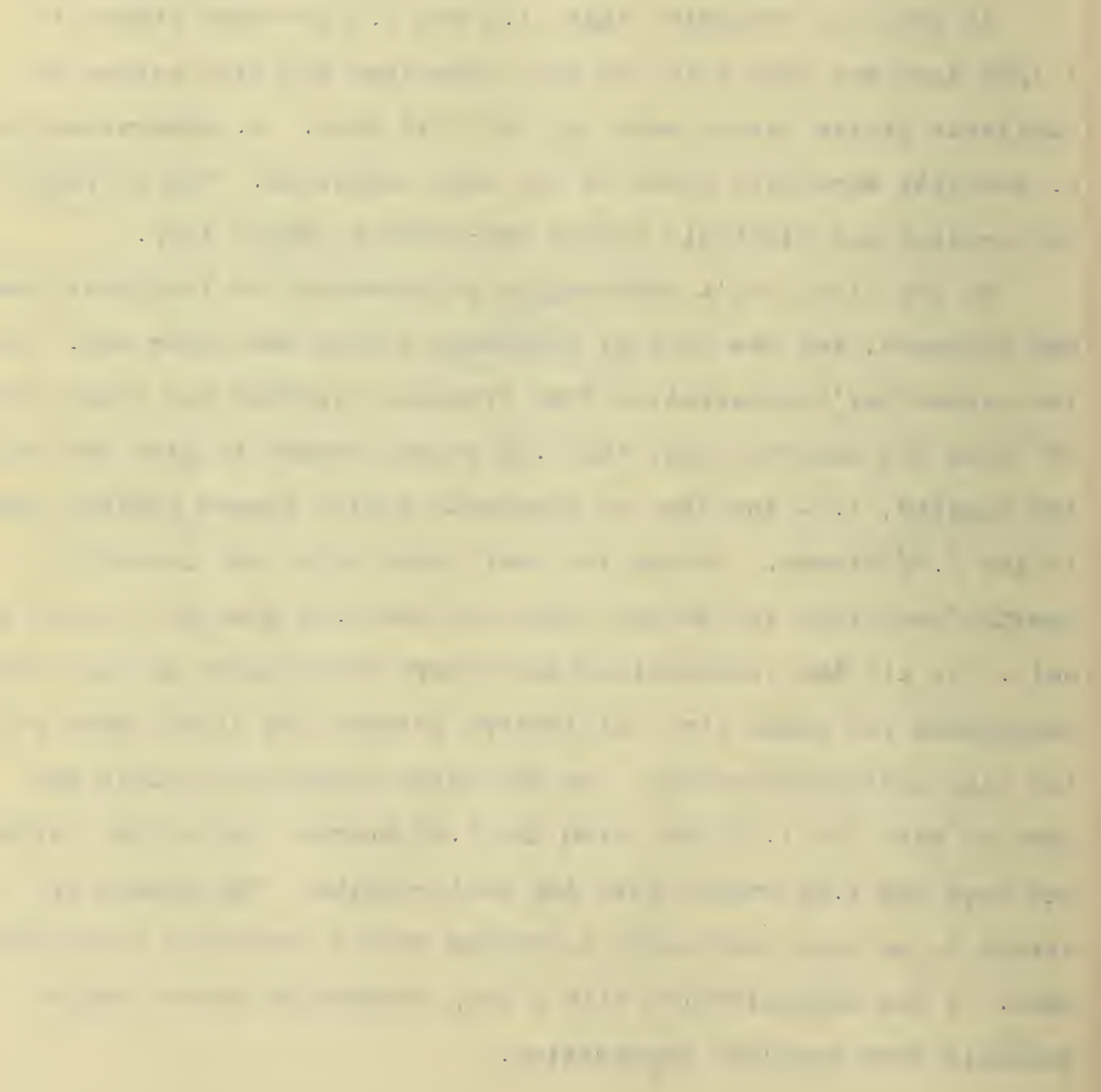
Table III. Growth and Diastasic Action on $I 1 / 2 \%$ Agar from I to 5 days inclusive with $1 \%$ and $2 \%$ potato starch.

\begin{tabular}{|c|c|c|c|c|c|c|c|c|c|c|c|c|}
\hline \multirow{4}{*}{ pays } & \multicolumn{12}{|c|}{ Percentages of Starch. } \\
\hline & \multicolumn{4}{|c|}{ B. mesentericus } & \multicolumn{4}{|c|}{ B. cereus } & \multicolumn{4}{|c|}{ B. vulgatus } \\
\hline & \multicolumn{2}{|c|}{$1 \%$} & \multicolumn{2}{|c|}{$2 \%$} & \multicolumn{2}{|c|}{$1 \%$} & \multicolumn{2}{|c|}{$2 \%$} & \multicolumn{2}{|c|}{$1 \%$} & \multicolumn{2}{|c|}{$2 \%$} \\
\hline & ${ }^{*} \mathrm{G}$ & A & G & A & G & A & C & A & G & A & G & A \\
\hline 1. & 14.5 & 21 & 12 & 18 & 5.0 & 11 & 9 & 10 & 1 & 12 & 1 & 10 \\
\hline 2. & 23 & 26 & 22 & 25 & 3.5 & 15 & 15 & 17 & 2 & 16 & 3 & 12 \\
\hline 3. & 35 & 38 & 30 & 36 & 13 & 22 & 22 & 25 & 10 & 24 & & 20 \\
\hline 4. & 48.5 & 55 & 42.0 & 46 & 23 & 24 & 17 & 28 & 12 & 28 & 12 & 23 \\
\hline 5. & 48.5 & 51 & 46.0 & 50 & 25 & 36 & 29 & 36 & 14 & 31 & 14 & 24 \\
\hline
\end{tabular}

${ }^{*} \mathrm{G}=$ Growth in millimeters.

*A. = Figures indicate width of clear zone in millimeters. 



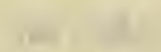

$$
\begin{aligned}
& \text { is me }
\end{aligned}
$$

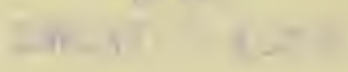


D. It now seemed to be important to determine whether the kind of starch had any influence on its availability for bacteria. The same technique as previous experiments was used. Plates of $2.0 \%$ agar with pea, wheat, corn, oat, arrowroot, and rice starch were prepared and observations made after one and five days.

In preparing these plates equal amounts of cold water were added to the starches to make a thin paste; this emulsion was poured slowly into the hot melted agar, stirring constantly, brought to a boil, tubed, sterilized, plated, cooled and streaked as in the previous experiment.

The appearance of these starch agar plates was different from the previous plates. With these starches, a 2 per cent starch agar plate was more opaque than the agar containing $11 / 2$ per cent of starch, the zone of action could also be seen more clearly before Iodine was added. It seemed to be more transparent, or granular than the rest of the agar. This was true with the six different starches used.

is a result of the observations made after one day's incubation, the results of which are given in Table IVa, it seems probable that the starches were not soluble ones.

on the oat starch the diastasic action with all of the organ1sms had probably not proceeded farther than between the soluble and erythrodextrin stage, as shown by the purple color. The appearance of purple specks on the background on all of the plates used for the one day observations, except where complete diastasic action had in part taken place, was further evidence of insoluble starch particles. 


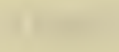

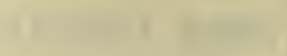

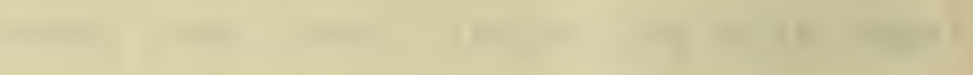

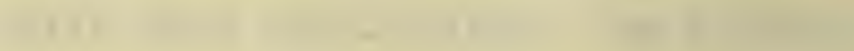

1
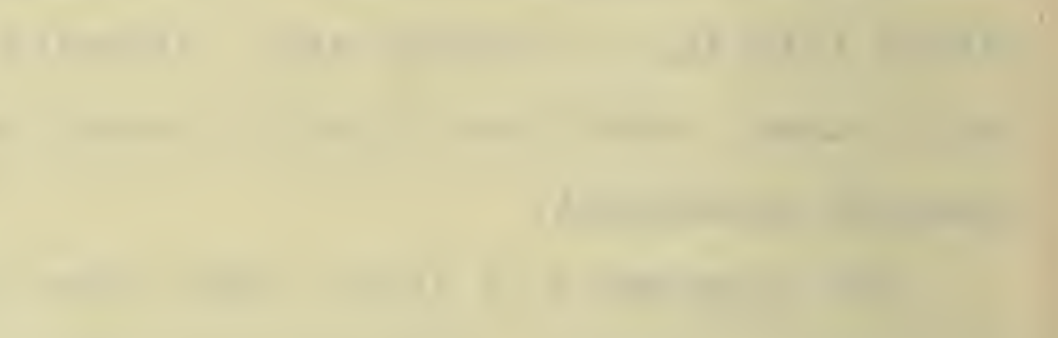

(1)

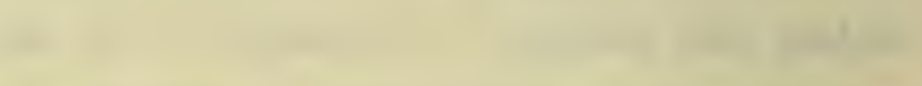
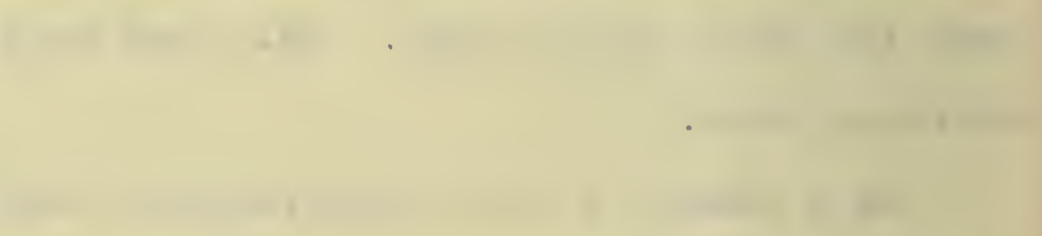

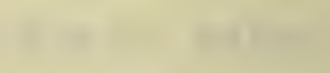

-
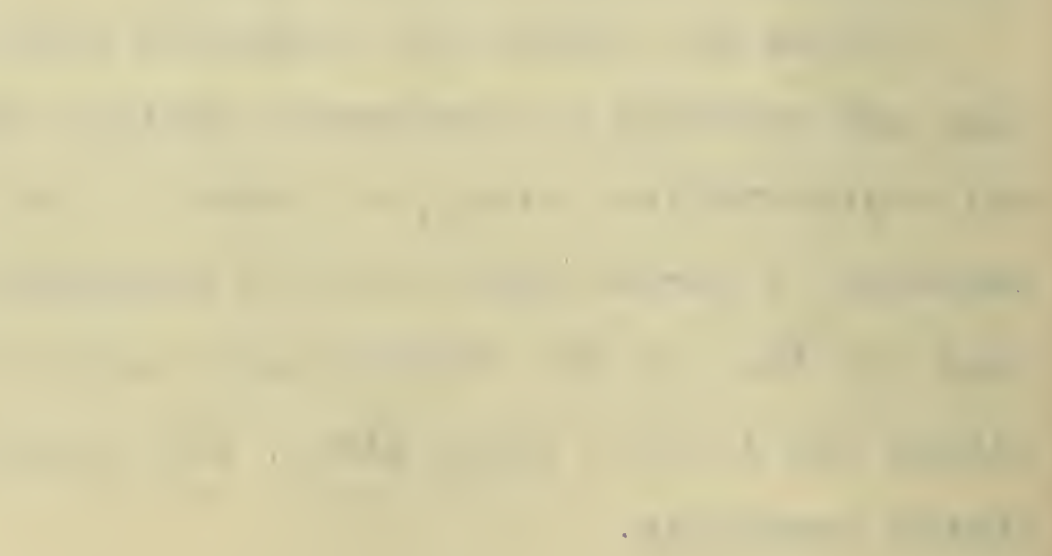


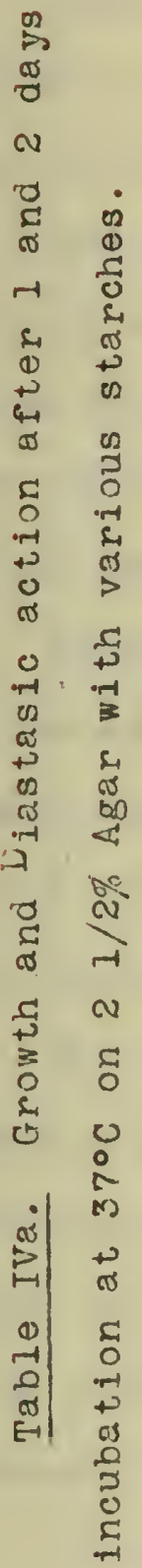

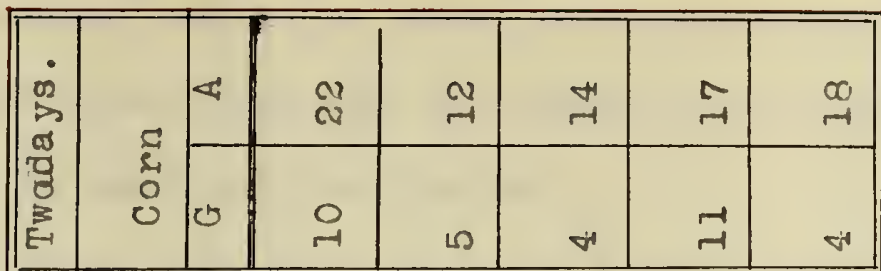

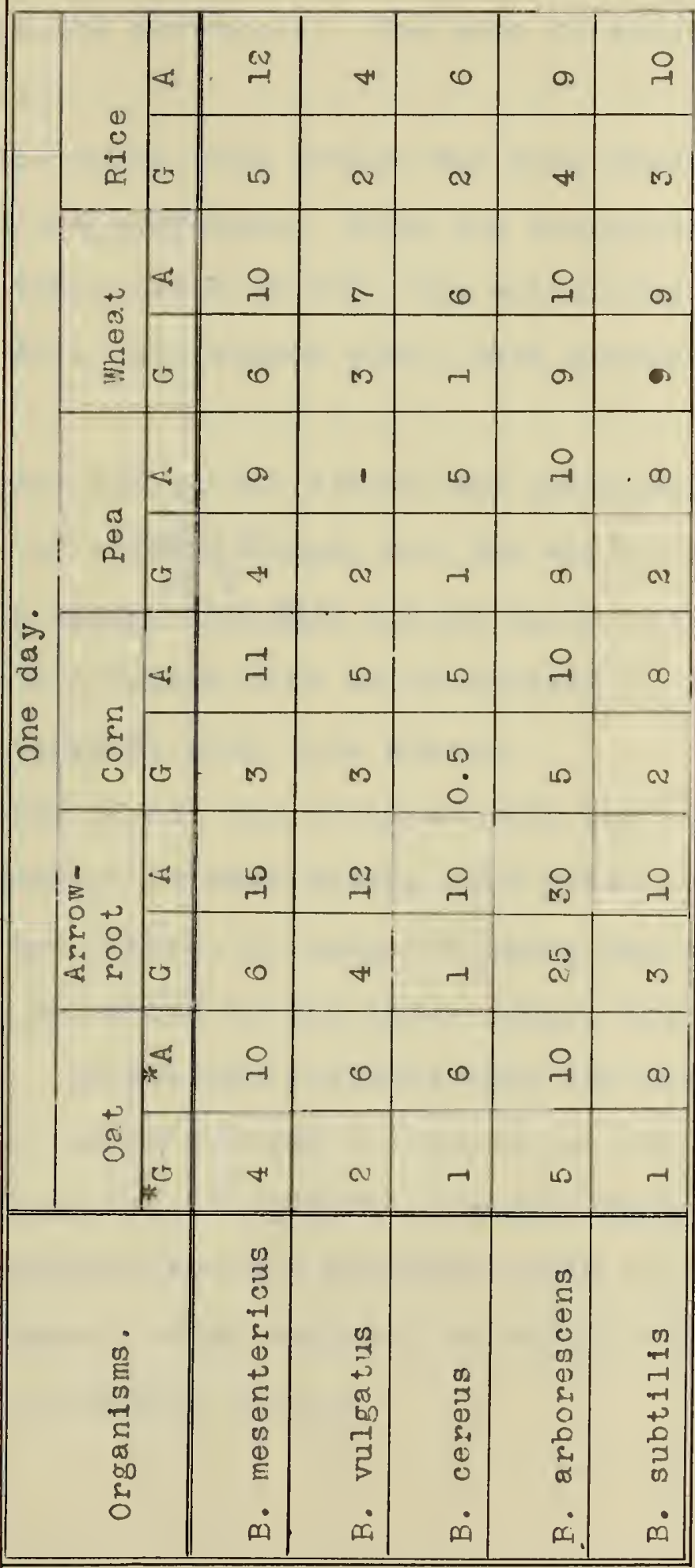



The diastasic action with the wheat starch seemed to have gone a little farther than with the oat starch, the erythrodextrin stage being visible in part of the plates.

With the corn starch the action was a little stronger, but not as strong as with the arrowroot. The zone of action was regular but not complete.

The greenish blue color with Iodine was more decided with the pea starch than with the arrowroot. With the exception of B. cereus where no action had taken place at all, the action was similar to that of arrowroot. With this starch also, dark specks were visible in the background.

With the arrowroot starch the action had proceeded in part to the achro-dextrin or inaltose stage, but the whole zone of diastasic action was not clear, the dark specks again being visible in the purple zone. A greenish blue color instead of the ordinary blue with Iodine was present with this starch.

The weakest action of all was obtained with the rice starch; larger and greater numbers of dark specks were present in the zone of action than with the others, B. vulgatus being the only one with which the action had proceeded to the clear stage, the others all had a purplish tinge. This might indicate that the different starches had different resistivities to enzymic action.

According to the action, in general, from weakest to strongest, on the one day observation the starches would be arranged as follows: rice, oat, wheat, corn, pea, and arrowroot. Soluble potato starch gave the strongest action. 


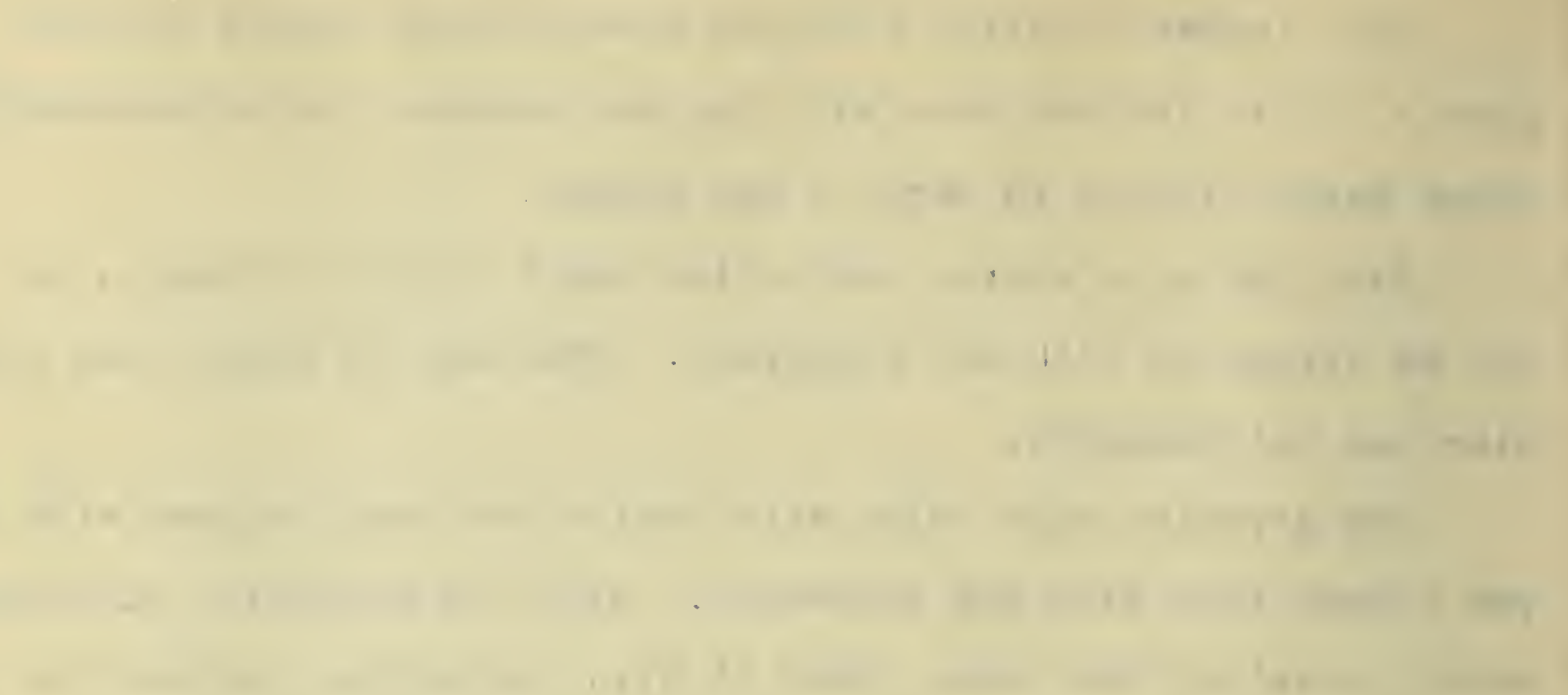

1

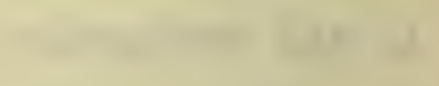

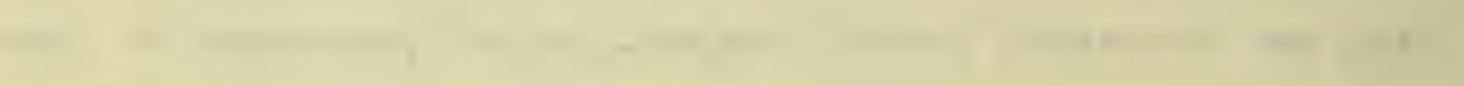

$-$
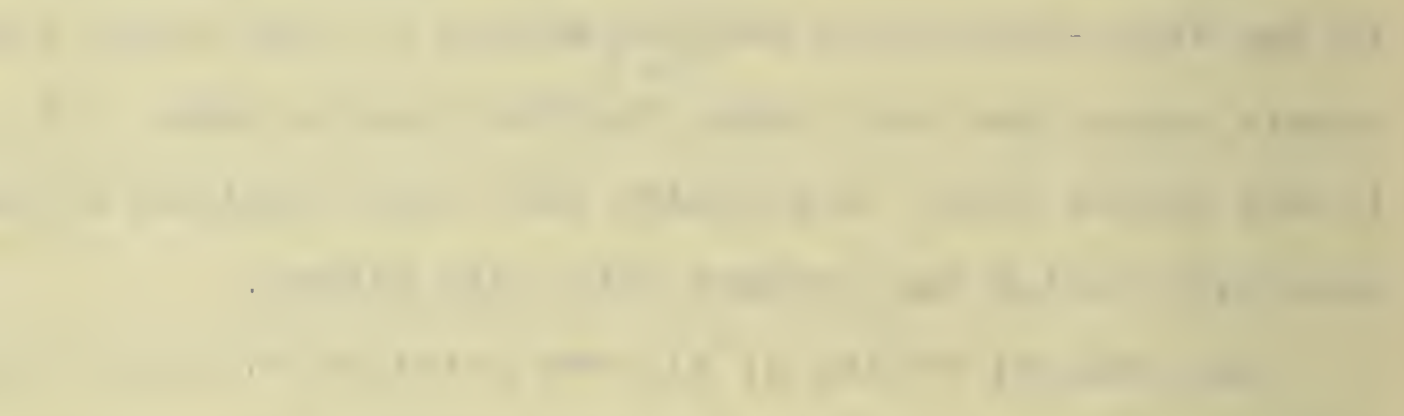
(1)

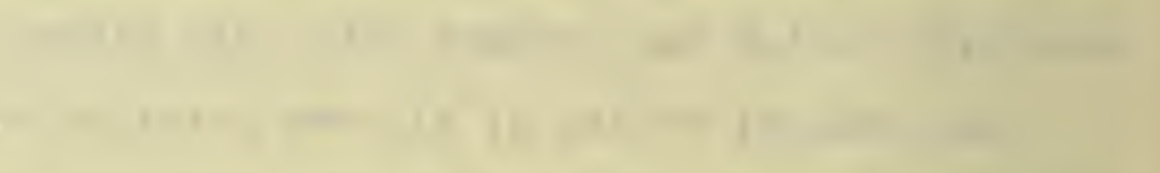

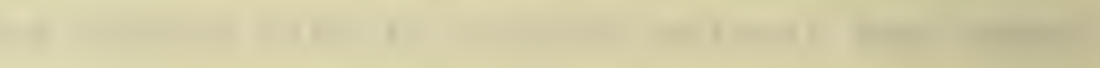

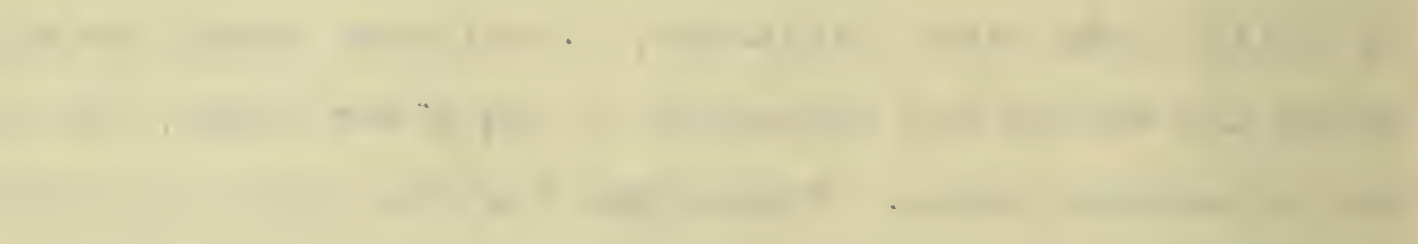

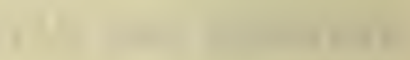

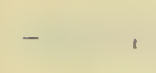

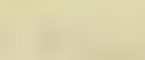

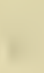


A two-day observation was made on corn starch to see how the result compared with the one-day. The action had in part gone to the colorless stage as shown in Table IVa, but the intermediate cleavage stages were also present. This shows that with these starches a different time element would have to be consicered than for potato starch as worked out in the first experiments. For this reason similar plates were incubated at $37^{\circ} \mathrm{C}$ for seven days and tested, with results as given in Table IVb.

After seven days incubation at $37^{\circ} \mathrm{C}$ vie $z$ one of action with each organism was much more extended than after one day incubation, but with no organism hed the action gone to completion. In general the action had gone farther, but the different stages of diastasic action were visible. There were specks also in the background.

With rice, complete action had taken place on part of the zone, but here as with the one-day observation larger and more particles of undigested starch were present.

In the oat starch the action had proceeded farther with the result that $B$. mesentericus, $B$. vulgatus, and $B$. subtilis gave a zone of clear action, first pink, then purplish; but with B.cereus and B. arborescens although four times in width, the color change was still in the light purple stage. The action with the wheat was sinilar to that of the oat starch.

With corn the we of decomposttion as with the other starches, was of greater width, but with only two organisms, B. vulgatus and $B$. subtilis, had a clear zone appeared and that only on a portion of the field. 


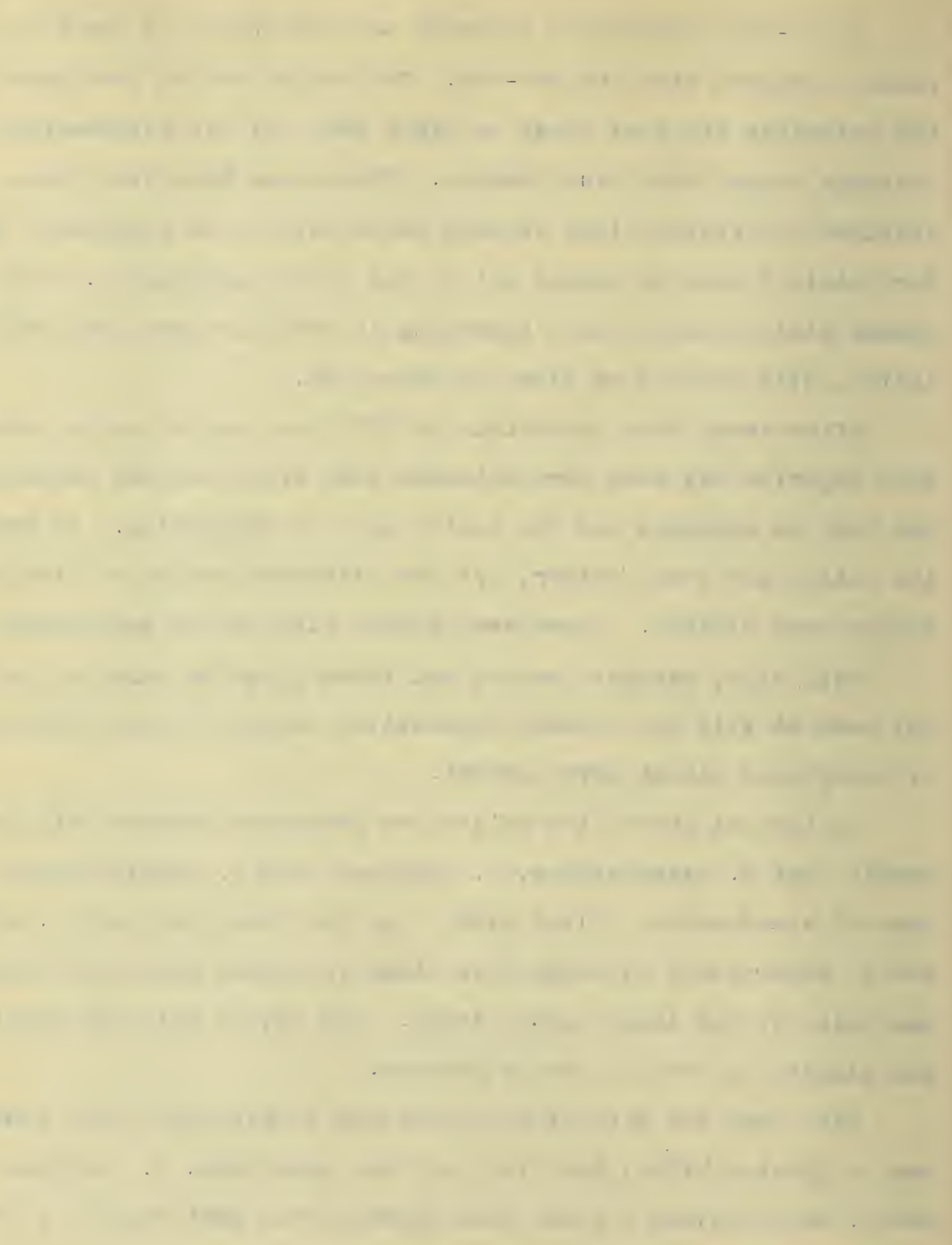




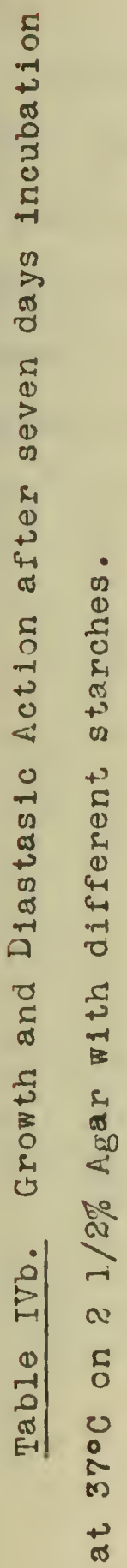

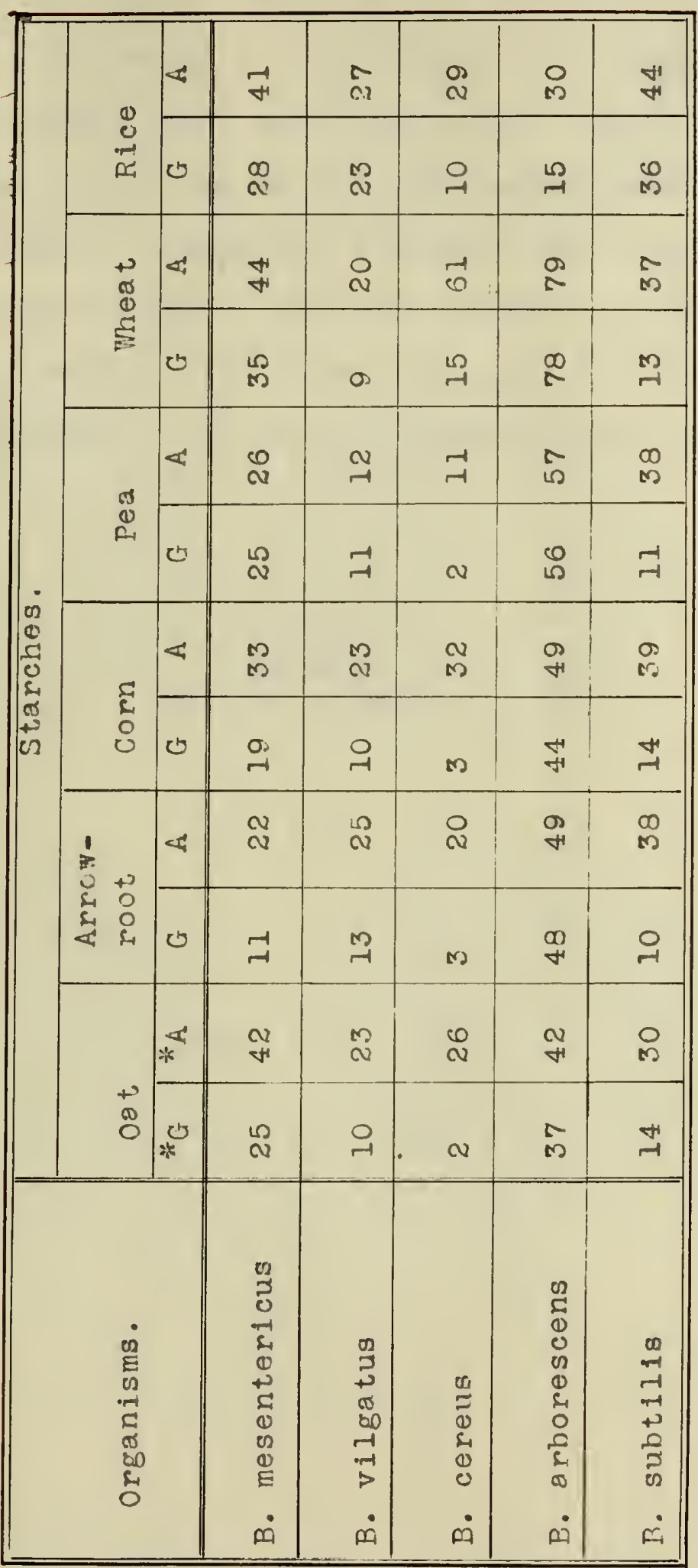



Again with pea starch the same two organisms gave a clear zone on a portion of the field. None of the organisms with the arrowroot starch had proceeded to the achrodextrin stage.

This observation shows that even with seven days incubation a.t $37^{\circ} \mathrm{C}$ these different starches do not Eive satisfactory results as a test for the action of diastasic enzymes. The starches used evident.ly were not soluble ones. With the soluble potato starch prepared by Lintner's method, it is probable that the celis are ruptured and their contents more readily available for the action of the enzymes. 


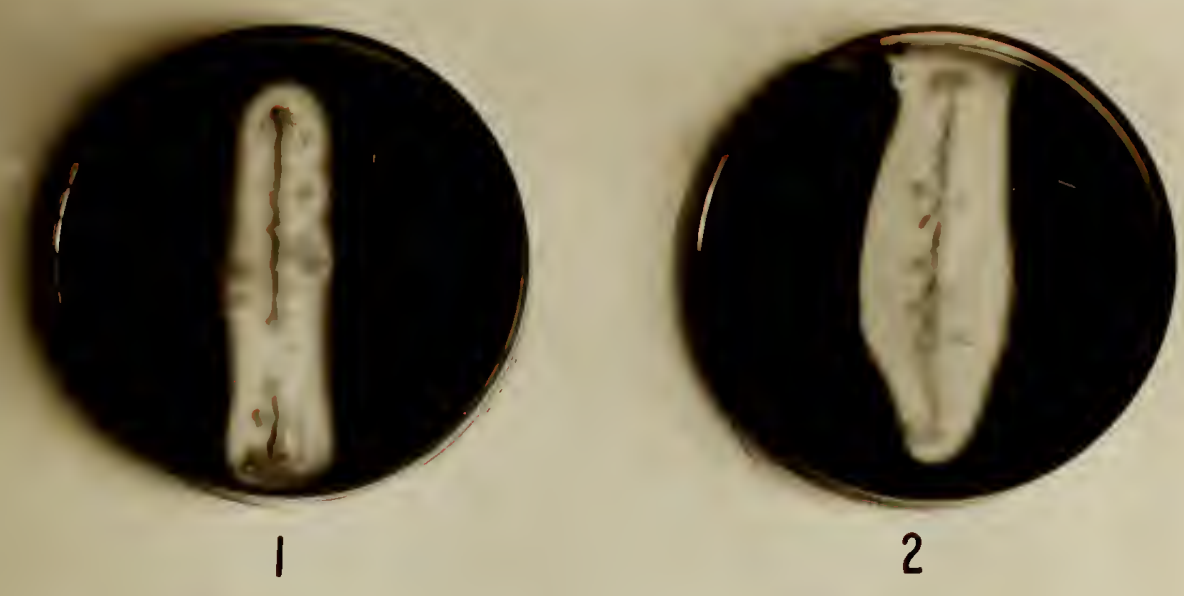

45.
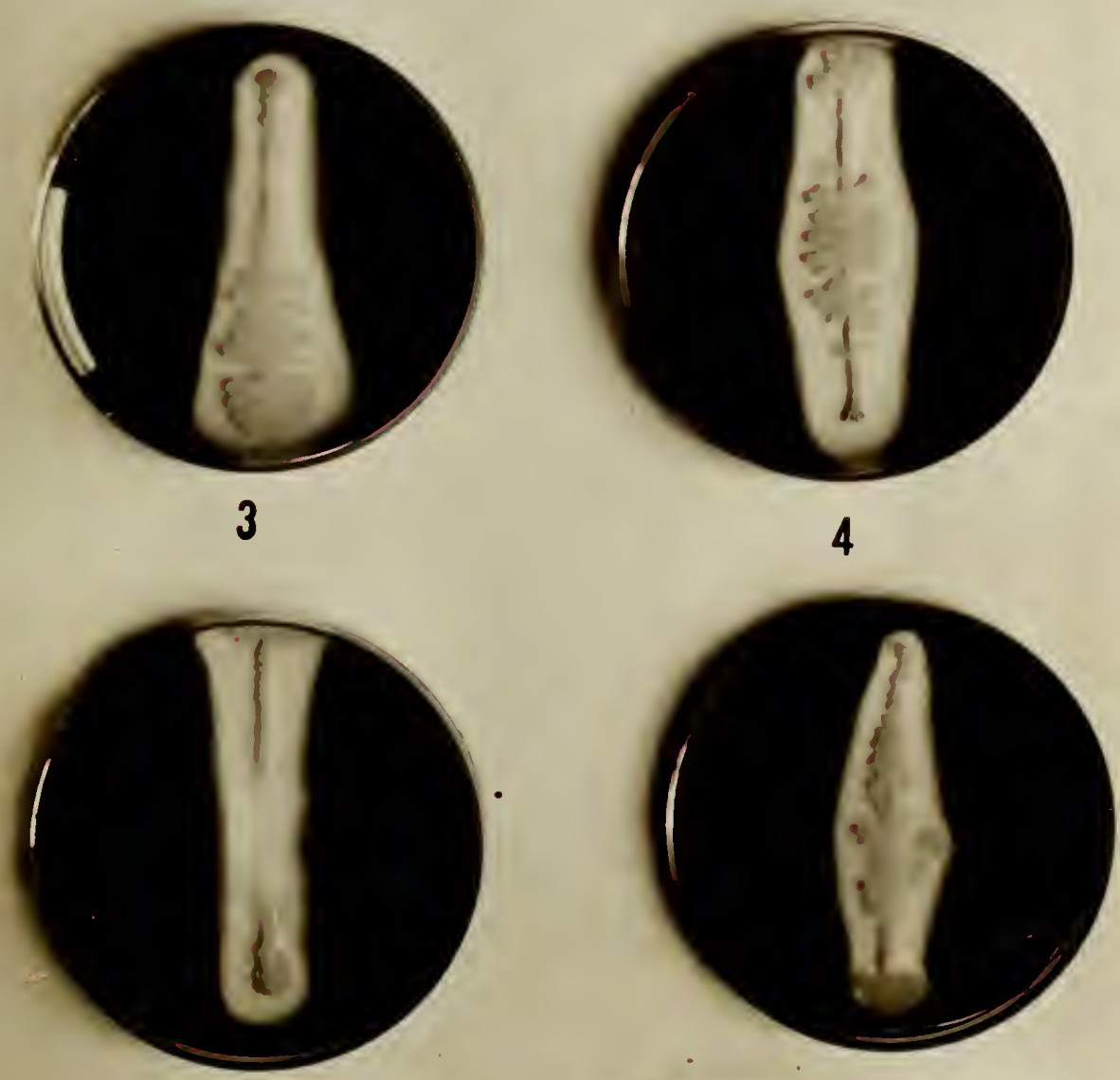

5

6.

Fig. 4. Showing the Effect of Different Starches on Diastasic Action With B. vulgatus After Seven Days Incubation at $37^{\circ} \mathrm{C}$ on $21 / 2 \%$ Agar.

$$
\begin{aligned}
& 1 \text { - Wheat Starch. } \\
& 2 \text { - Oat " } \\
& 3 \text { - Corn }
\end{aligned}
$$$$
4 \text { - Arrowroot Starch. }
$$$$
5 \text { - Pea }
$$$$
6 \text { - Rice }
$$ 

E. After determining by the plate method that $1 \%$ of soluble potato starch and $11 / 2 \%$ agar gave the best results for diastasic action, an attampt was made to determine the best method by the use of synthetic media using Frankel's solution which has the following composition:

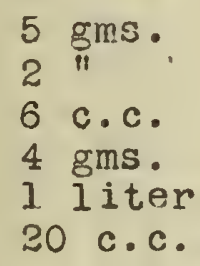

sodium chloride. monocalcium phosphate. ammonium lactate. as paragin. distilied water. $n / 1$ sodium hydroxide.

Tubes of this medium containing 10 c.c. were prepared with increasing percentages of soluble potato starch from 1 to $5 \%$ inclusive. After $2,3,4,5,6$ and 9 days, incubation at $37^{\circ} \mathrm{C}$ tests were made with Iodine in KI, and with Benedict's Solution, the results of which are given in Table V.

In the Iodine test, when necessary, both the Iodine and the starch media were diluted 80 as to detect the delicate shades of color which indicate the various stages in the decomposition of starch.

In the Benedict's test for reducing sugars, four c.c. of the starch solution to be tested were added to a tube containing five c.c. of Benedict's Solution. The mixture was then boiled over a bunsen flame for two minutes. Although the media with each percentage was brought to a boil before tubing, a perfect emulsion had not been formed, for after standing a short time even the $1 \%$ starch settled leaving a clear portion at the top of the tube. on longer incubation this clear portion increased, and in the tests made before stirring the contents of the tube, positive results were obtained sooner than in the thoroughly mixed portion. 



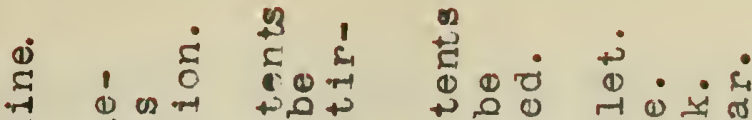

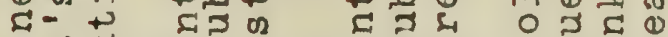

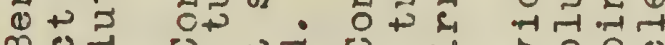

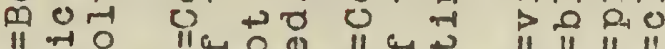

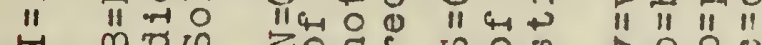

H M

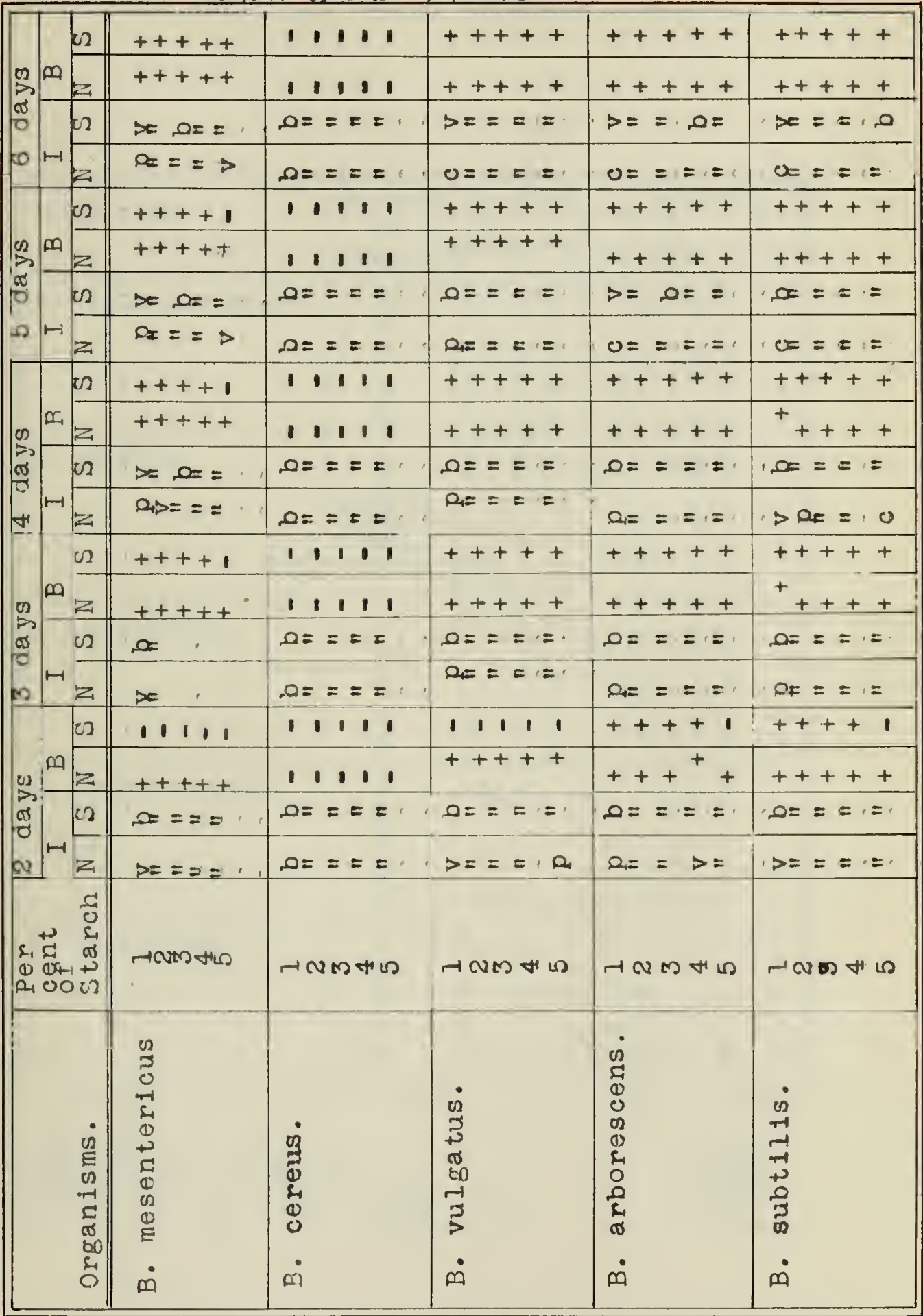


111111

$1 \quad 1 \quad 1 \quad 1 \quad 1$

$111 ; 1+1$

$1 \quad 1 \quad 1 \quad 1 \quad 1$

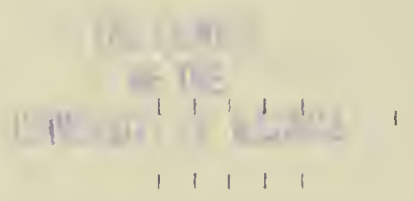

1

।

$\begin{array}{llllllllllll}1 & 1 & 1 & 1 & 1 & 1 & 1 & 1 & 1 & 1 & 1 & 1\end{array}$ 
Table Vb. Diastasic Action in Frankel's Solution After 9 and 12 Days Incubation at $37^{\circ} \mathrm{C}$.

\begin{tabular}{|c|c|c|c|c|c|c|c|c|c|}
\hline \multirow{3}{*}{ Organism. } & \multirow{3}{*}{$\begin{array}{l}\text { Percent } \\
\text { of } \\
\text { starch. }\end{array}$} & \multicolumn{4}{|c|}{9 days. } & \multicolumn{4}{|c|}{ 12days. } \\
\hline & & $I$ & & 1 & 3 & & & & B \\
\hline & & & 5 & $\mathrm{~N}$ & $S$ & & S & & $S$ \\
\hline B. mesentericus. & $\begin{array}{l}1 \\
2 \\
3 \\
4 \\
5\end{array}$ & $\begin{array}{l}c \\
" 1 \\
" 1 " \\
" 1 \\
\bar{~}\end{array}$ & $\begin{array}{l}V \\
" 1 \\
b \\
" 1 \\
" ~\end{array}$ & $\begin{array}{l}+ \\
+ \\
+ \\
+ \\
+ \\
+\end{array}$ & $\begin{array}{l}+ \\
+ \\
+ \\
+ \\
+\end{array}$ & $\mid \begin{array}{l}c \\
" 1 \\
" 1 \\
\overline{11} \\
\overline{1}\end{array}$ & $\begin{array}{l}\mathrm{p} \\
" 1 \\
\mathrm{y} \\
\mathrm{v} \\
\mathrm{b}\end{array}$ & $\begin{array}{l}+ \\
+ \\
+ \\
+ \\
+ \\
+\end{array}$ & $\begin{array}{l}+ \\
+ \\
+ \\
+ \\
+\end{array}$ \\
\hline B. cereus. & $\begin{array}{l}1 \\
2 \\
3 \\
4 \\
5\end{array}$ & $\begin{array}{l}v \\
" 1 " \\
" 1 \\
" 1 \\
" 1\end{array}$ & $\begin{array}{l}\vec{V} \\
" 1 \\
" 1 \\
\text { b } \\
" 1\end{array}$ & $\begin{array}{l}+ \\
+ \\
+ \\
+ \\
+\end{array}$ & $\begin{array}{l}+ \\
+ \\
+ \\
+ \\
-\end{array}$ & $\begin{array}{l}c \\
" 1 \\
" 1 \\
\overline{11} \\
i " \\
.\end{array}$ & $\begin{array}{l}p \\
\text { " } \\
\mathrm{v} \\
\mathrm{f} \\
\mathrm{b}\end{array}$ & $\begin{array}{l}+ \\
+ \\
+ \\
+ \\
+\end{array}$ & $\begin{array}{l}t \\
+ \\
+ \\
+\end{array}$ \\
\hline B. vulgatus. & $\begin{array}{l}1 \\
2 \\
3 \\
4 \\
5\end{array}$ & $\begin{array}{l}c \\
\text { " } \\
" 1 \\
" 1 \\
" !\end{array}$ & $\begin{array}{l}\mathrm{V} \\
\text { " } \\
" 1 \\
" 1 \\
" 1\end{array}$ & $\begin{array}{l}+ \\
+ \\
+ \\
+ \\
+ \\
+\end{array}$ & $\begin{array}{l}+ \\
+ \\
+ \\
+ \\
+\end{array}$ & 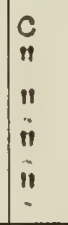 & & $\begin{array}{l}+ \\
+ \\
+ \\
+ \\
+\end{array}$ & $\begin{array}{l}+ \\
+ \\
+ \\
+ \\
+\end{array}$ \\
\hline B. arborescens. & $\begin{array}{l}1 \\
2 \\
3 \\
4 \\
5\end{array}$ & $\begin{array}{l}c \\
" 1 " \\
" 1 \\
" 1 \\
" 1\end{array}$ & $\begin{array}{l}p \\
\text { n } \\
\text { v } \\
\text { " } \\
1 "\end{array}$ & $\begin{array}{l}+ \\
+ \\
+ \\
+ \\
+\end{array}$ & $\begin{array}{l}+ \\
+ \\
+ \\
+ \\
+\end{array}$ & $\begin{array}{l}c \\
" 1 \\
" 1 " \\
" 1 "\end{array}$ & $\begin{array}{l}c \\
" 1 \\
p \\
v \\
\text { " }\end{array}$ & $\begin{array}{l}+ \\
+ \\
+ \\
+ \\
+ \\
+\end{array}$ & $\begin{array}{l}t \\
t \\
+ \\
+\end{array}$ \\
\hline B. subtilis. & $\begin{array}{l}1 \\
2 \\
3 \\
4 \\
5\end{array}$ & $\begin{array}{l}c \\
11 \\
n \\
n \\
n \\
11\end{array}$ & $\begin{array}{l}p \\
\text { p } \\
\text { v } \\
" 1 \\
"\end{array}$ & $\begin{array}{l}+ \\
+ \\
+ \\
+ \\
+\end{array}$ & $\begin{array}{l}+ \\
+ \\
+ \\
+ \\
+\end{array}$ & $\begin{array}{l}c \\
" 1 \\
n " \\
i n \\
i n \\
i n\end{array}$ & & $\begin{array}{l}+ \\
+ \\
+ \\
+ \\
+ \\
+\end{array}$ & $\begin{array}{l}+ \\
+ \\
+ \\
+ \\
+\end{array}$ \\
\hline
\end{tabular}

$I=I o d i n e$.

$B \neq$ Benedict's solution.

$\mathrm{N}=$ Contents of tube not stirred. $\mathrm{S}=$ $c=c$ lear.

$\mathrm{p}=\mathrm{plnk}$.

$v=$ violet.

$\mathrm{b}=\mathrm{blu} \theta$. 

This ould indicate that the lighter top part was subject to diastasic action quicker than the heavier lower portion. This may also have been due to the fact that the test organisms were aerobic and grew more readily in the upper stretches of the medium.

As in previous results, B. cereus required a long incubation perlod for diastasic action to take place. B. arborescens and B. subtilis gave positive action on the second day with the smaller percentages of starch, and on the third day with all percentages. B. vulgatus gave no action with the stirred contents of the tube on the second day, but complete action on the third day. B. mesentericus did not give action until the fourth day, and $B$. cereus did not give action at all.

This shows variability in the different organisms as to the production of diastases. 

Being unable to obtain asparagin, Uschinsky's Protein Free Medlum (lacking the asparagin) was used, having the following composition:

$\begin{array}{lc}\text { Ammonium lactate } & 10.0 \mathrm{gm} . \\ \text { Sodium chloride } & 5.0 \\ \left.\text { Magnisium sulphate ( } \mathrm{M}_{\mathrm{SO}} \mathrm{SO}_{4}-7 \mathrm{H}_{2} \mathrm{O}\right) & 0.2 \\ \left.\left.\text { Calcium chloride ( } \mathrm{C}_{2} \mathrm{CI}_{2}\right)_{\mathrm{K}}\right) & 0.1 \\ \text { Dipotassium phosphate }(\mathrm{K} \mathrm{HO}) & 1.0 \\ \text { Distilled water } & 1000 \text { c.c. }\end{array}$

To deternine whether or not this media would sustain growth, each organism was inoculated into $5 \mathrm{c.c}$. of the medium and incubated at $37^{\circ} \mathrm{C}$ for two days; no growth occurred except in organism III where a scum formed. A pinch of ammonium chloride was added to tubes I and II, incubated and very slight growth occurred.

To determine the effect of the concentration of starch on the action of bacterial diastase, percentages of starch from 0.1 to 3.0 inclusive in the above media plus a pinch of ammoniun chloride were prepared. The test organisms were inoculated into tubes containing $5 \mathrm{c} . \mathrm{c}$. of this starch media and incubated at $37^{\circ} \mathrm{C}$ for five days. Controls were run with each per cent of starch. When tested on the fifth day with Iodine and Benedict, there was no evdence that action had taken place. Certain random tubes were tested in a hanging drop for the organism, and onplain agar streaks for growth. Growth resulted on all of the slants.

Since Uschinsky's media plus ammonium chloride and lacking asparagin dia not givo satisfactory results, lain broth was used with the same series of percentag es of starch, and tested after five ciays incubation at $37^{\circ} \mathrm{C}$. The results in Table VI seem to indicate that $1 \%$ of starch is necessary to give the best results. 


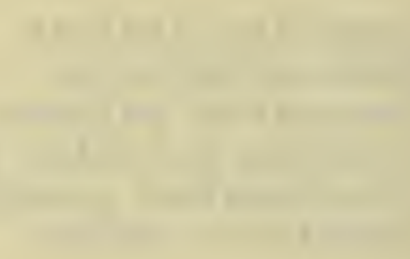


ב

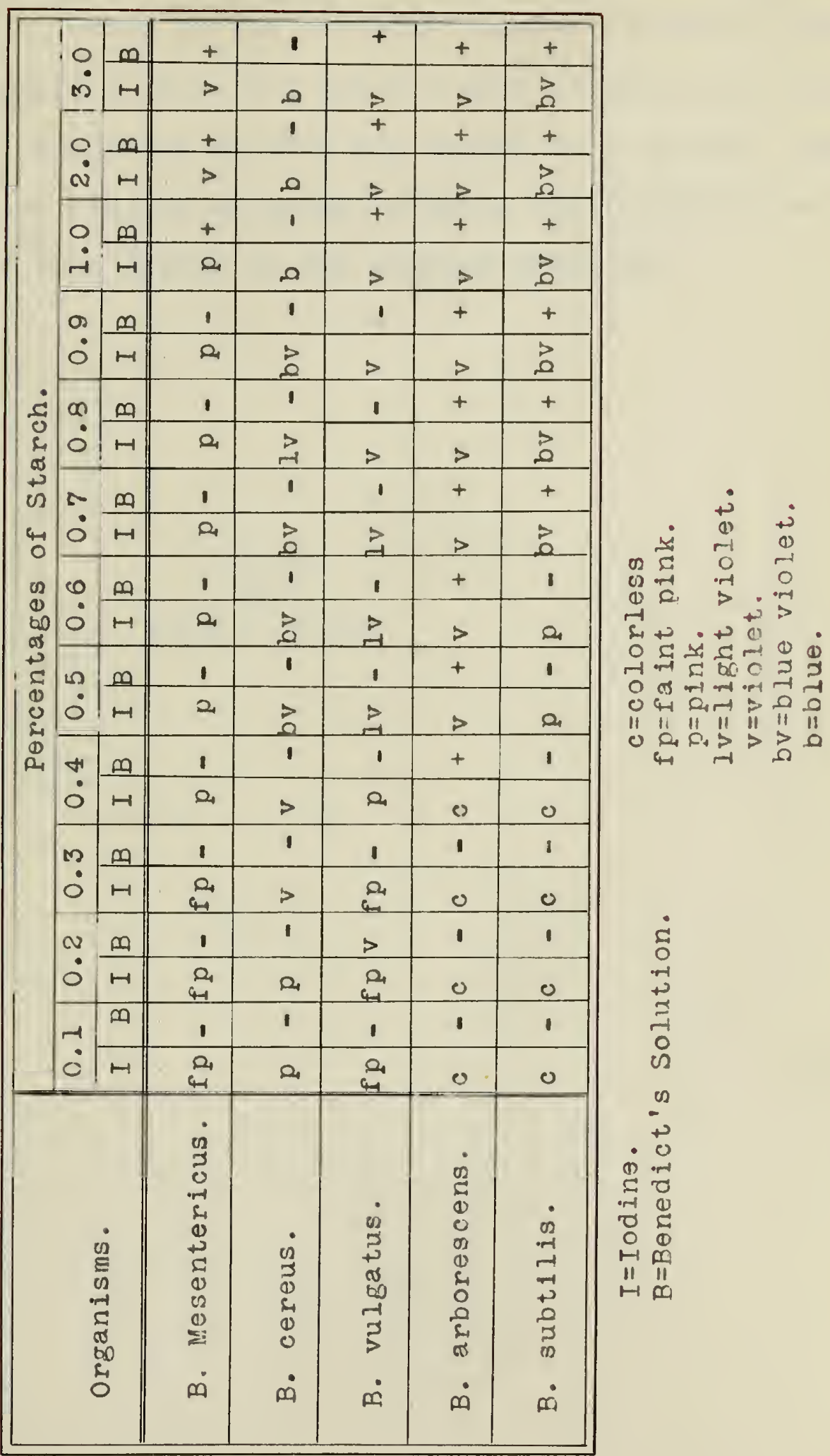



In order to determine whether or not a shorter incubation poriod would be a factor in the previous results (Table VI) percentages of starch $0.1,0.2,0.3$ and 0.4 were prepared with plain Broth as before, incubated at $37^{\circ} \mathrm{C}$ and tested on 1,2 and 3 days, respectively. The results as given in Table VII indicate that the time element may be a factor in the results obtained. 

Table VII. Diastasic Action in Starch Broth with $0.1,0.2,0.3$ and 0.4 percents of Starch, After Incubation at $37^{\circ} \mathrm{C}$ for 1,2 and 3 Days.

\begin{tabular}{|c|c|c|c|c|c|c|c|c|}
\hline \multirow{3}{*}{ Organisms. } & \multicolumn{8}{|c|}{ One Day. } \\
\hline & \multicolumn{2}{|c|}{$0.1 \%$} & \multicolumn{2}{|c|}{$0.2 \%$} & \multicolumn{2}{|c|}{$0.3 \%$} & \multicolumn{2}{|c|}{$0.4 \%$} \\
\hline & I & $\mathrm{B}$ & I & B & I & $\mathrm{B}$ & I & $\mathrm{B}$ \\
\hline R. mesentericus. & $f p$ & - & $f p$ & - & Iv & - & $1 . \mathrm{V}$ & - \\
\hline B. cereus. & $\mathrm{b}$ & - & $\mathrm{b}$ & - & b & - & $\mathrm{b}$ & - \\
\hline B. vulgatus. & $\mathrm{v}$ & - & $\mathrm{v}$ & - & b & - & $b$ & - \\
\hline B. arborescens. & $\mathrm{p}$ & - & Iv & - & Iv & - & Iv & - \\
\hline B. subtilis. & $f p$ & - & $\mathrm{v}$ & - & $\mathrm{v}$ & - & $\mathrm{v}$ & - \\
\hline \multirow{3}{*}{ organisms. } & \multicolumn{8}{|c|}{ Two Days. } \\
\hline & \multicolumn{2}{|c|}{$0.1 \%$} & \multicolumn{2}{|c|}{$0.2 \%$} & \multicolumn{2}{|c|}{$0.3 \%$} & \multicolumn{2}{|c|}{$0.4 \%$} \\
\hline & $I$ & $\mathrm{~B}$ & $I$ & $\mathrm{~B}$ & $I$ & $\mathrm{~B}$ & $I$ & $B$ \\
\hline B. mesentericus. & fp & - & $f p$ & - & $f p$ & - & fp & - \\
\hline B. cereus. & $\mathrm{b}$ & - & $\mathrm{b}$ & - & $\mathrm{b}$ & - & $\mathrm{b}$ & - \\
\hline B. vulgatus. & $f p$ & - & $f p$ & - & c & - & c & + \\
\hline B. arborescens. & $f p$ & - & $\mathrm{p}$ & - & Iv & - & IV & \pm \\
\hline B. subtilis. & $f p$ & - & $f p$ & - & IV & - & $\mathrm{v}$ & - \\
\hline \multirow{3}{*}{ Organisms. } & \multicolumn{8}{|c|}{ Three Days. } \\
\hline & \multicolumn{2}{|c|}{$0.1 \%$} & \multicolumn{2}{|c|}{$0.2 \%$} & \multicolumn{2}{|c|}{$0.3 \%$} & \multicolumn{2}{|c|}{$0.4 \%$} \\
\hline & I & $B$ & I & B & I & B & $I$ & $\mathrm{~B}$ \\
\hline B. mesentericus. & c & - & $c$ & - & $f p$ & - & $f p$ & - \\
\hline B. cereus. & $\mathrm{b}$ & - & $\mathrm{b}$ & - & $\mathrm{b}$ & - & b & - \\
\hline B. vulgatus. & c & - & c & - & c & - & $c$ & + \\
\hline B. arborescens. & $c$ & - & $\mathrm{p}$ & - & Iv & - & Iv & \pm \\
\hline B. subtilis. & c & - & c & - & $\mathrm{p}$ & - & $\mathrm{v}$ & - \\
\hline
\end{tabular}

$I=I 0 j i n e$.

$B=$ Benedict's Solution. fp $=$ faint pink.

$\mathrm{p}=\mathrm{p}$ ink.

lv $=$ light violet.

$\mathrm{v}=\mathrm{violet}$.

$c=$ colorless.

$\mathrm{b}=\mathrm{blue}$ 

Having determined that the lower and higher percentages of starch in Plain Broth were not as satisfactory as $1 \%$ starch and that the time element is a factor, tests were made with different Hydrogen ion concentrations to determine whether or not reaction is important in the bacterial autolysis of starch.

In doing this, a series of tubes of different Hydrogen ion concentrations were prepared for each organism, using $1 \%$ potato starch in Plain Broth. The acidity was obtained by adding 2 drops of C. P. Acetic acid to $20 \mathrm{c.c}$. of distilled water and to each series of ten tubes (for each organism), each tube containing 5 c.c. of starch broth was added $1,2,3,4,5,6,7,8,9$, and 10 drops. These tubes were sterilized, inoculated, incubated at $37^{\circ} \mathrm{C}$ and tested with Clark \& Lubs Indicators; with Iodine and with Benedict's Solution on the third and fifth days. Uninoculated controls were incubated and tested with each of the series of different percents of starch.

Testirg with clark \& Lubs was carried out by placing a drop of the starch broth to be testea into a depression in a test tablet, and adding a drop of the Indicator. The controls were tested also.

Eviciently not enough acid had been added, for with even the 10 drops, Thymol blue, which should be very sensitive to acid, gave its alkaline color, yellow. Brom thymol blue with a $P_{H}$ range of $6.0-7.6$ also gave a positive test for alkalinity in the controls. 

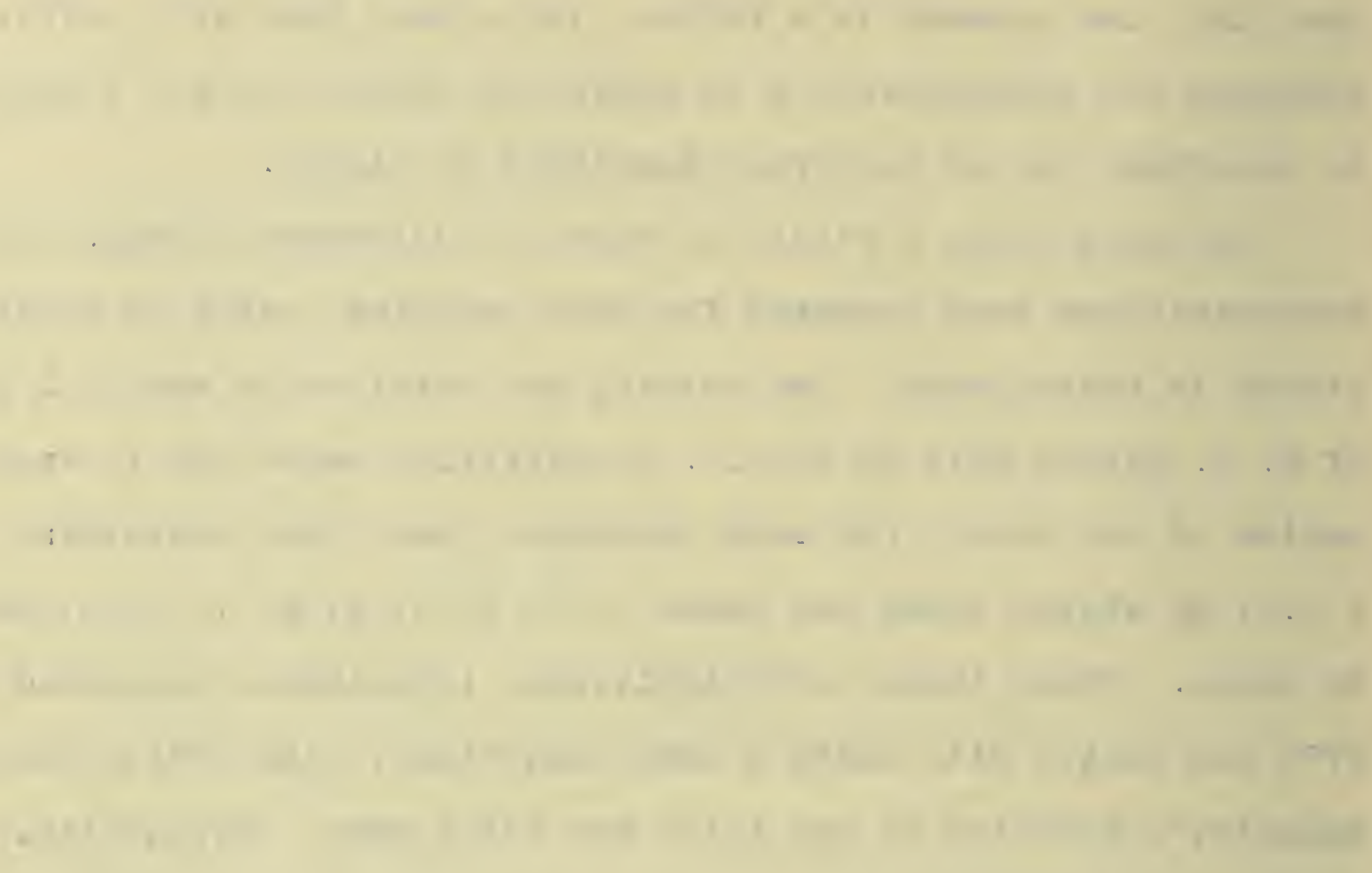

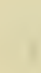

.

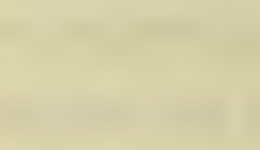

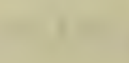

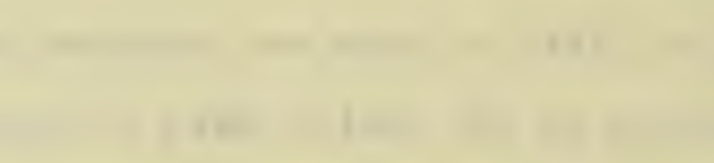

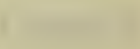

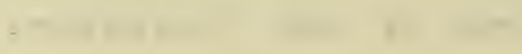

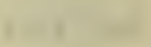
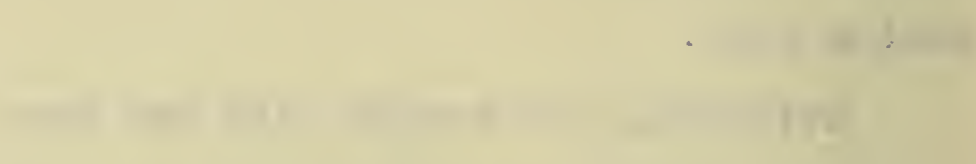
Most of the cultures gave an acid test with Brom thymol blue, Phenyl red, and Cresol red, in all of the tubes in the ontire range of acidity used, while the other indicators gave tests for alkalinity in practically all of the tubes in the entire range of acidity used.

One per cent starch broth was prepared and added to flasks in amounts so that when the final addition was made with $\mathrm{N} / 200 \mathrm{Hcl}$. and $\mathrm{N} / 200 \mathrm{NaOH}$ each of the ten flasks contained a total volume of 100 c.c.

Ten c.c. of the media were placed in each tube of the series of the ten different concentrations for each organism, sterilized, inoculated, and incubated at $37^{\circ} \mathrm{C}$ for five days. At the end of this time, the tubes were tested for Hydrogen ion concentration with the seven Clark \& Lubs Indicators used in the preceding experiment, and with phenolphthalein. They were also tested for color change with Iodine, and for sugar with Benedict's Reagent. The results which are given in Table VIII show that the correct range of acldity and alkalinity hac not been used. The data on the Hydrogen ion as carried out here is not conclusive. 


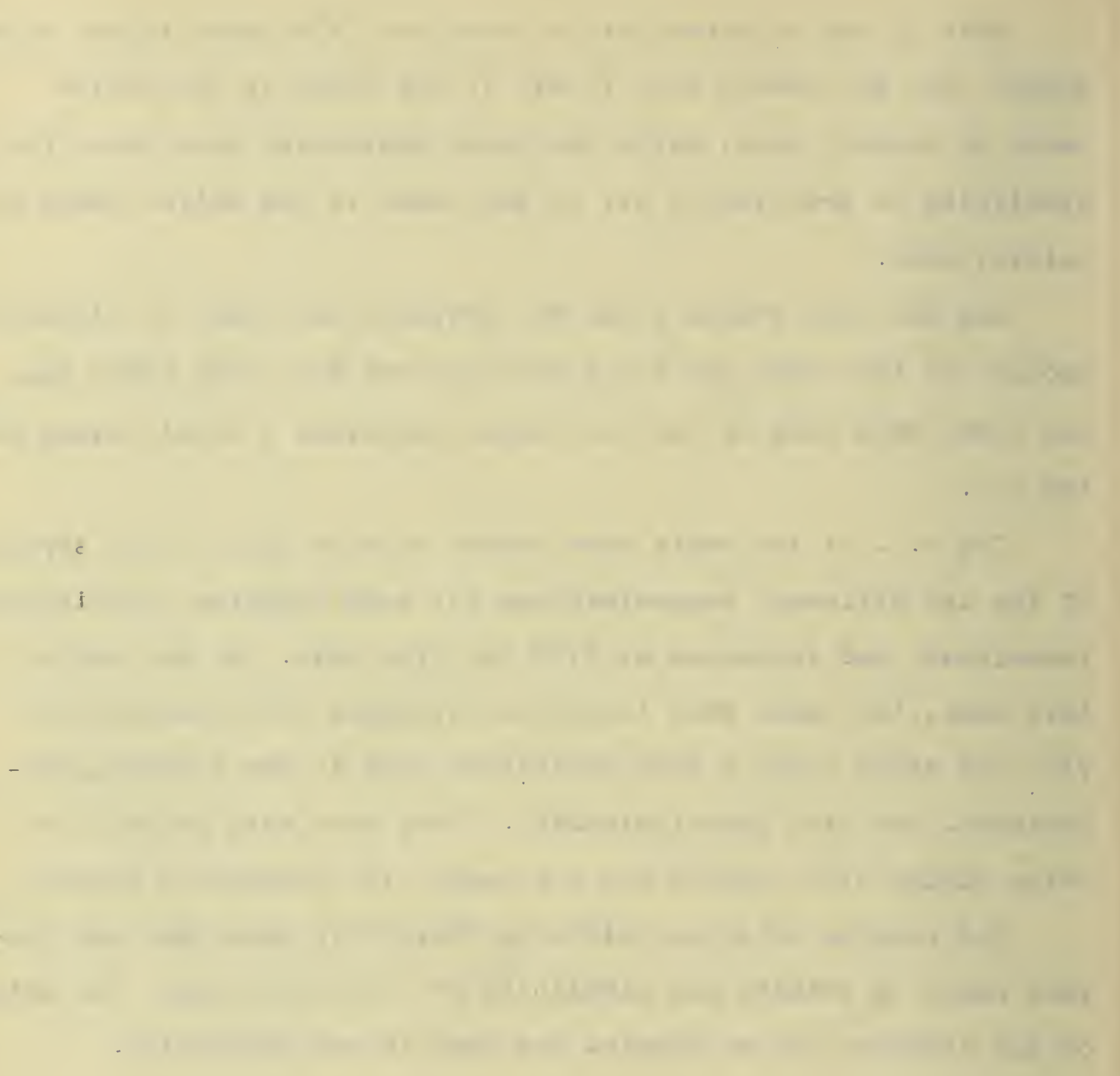




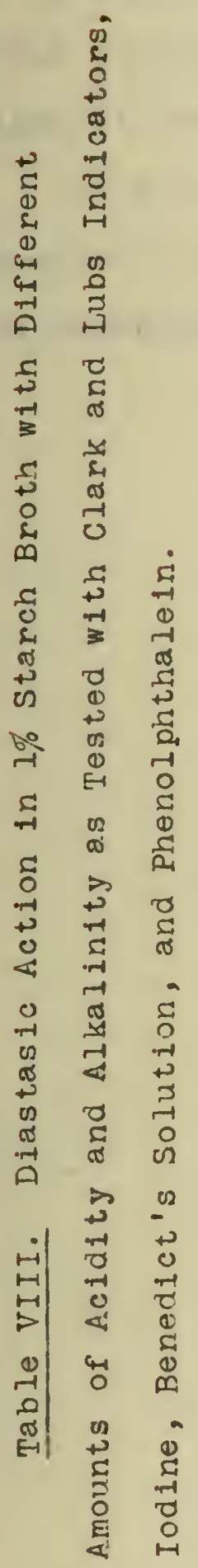

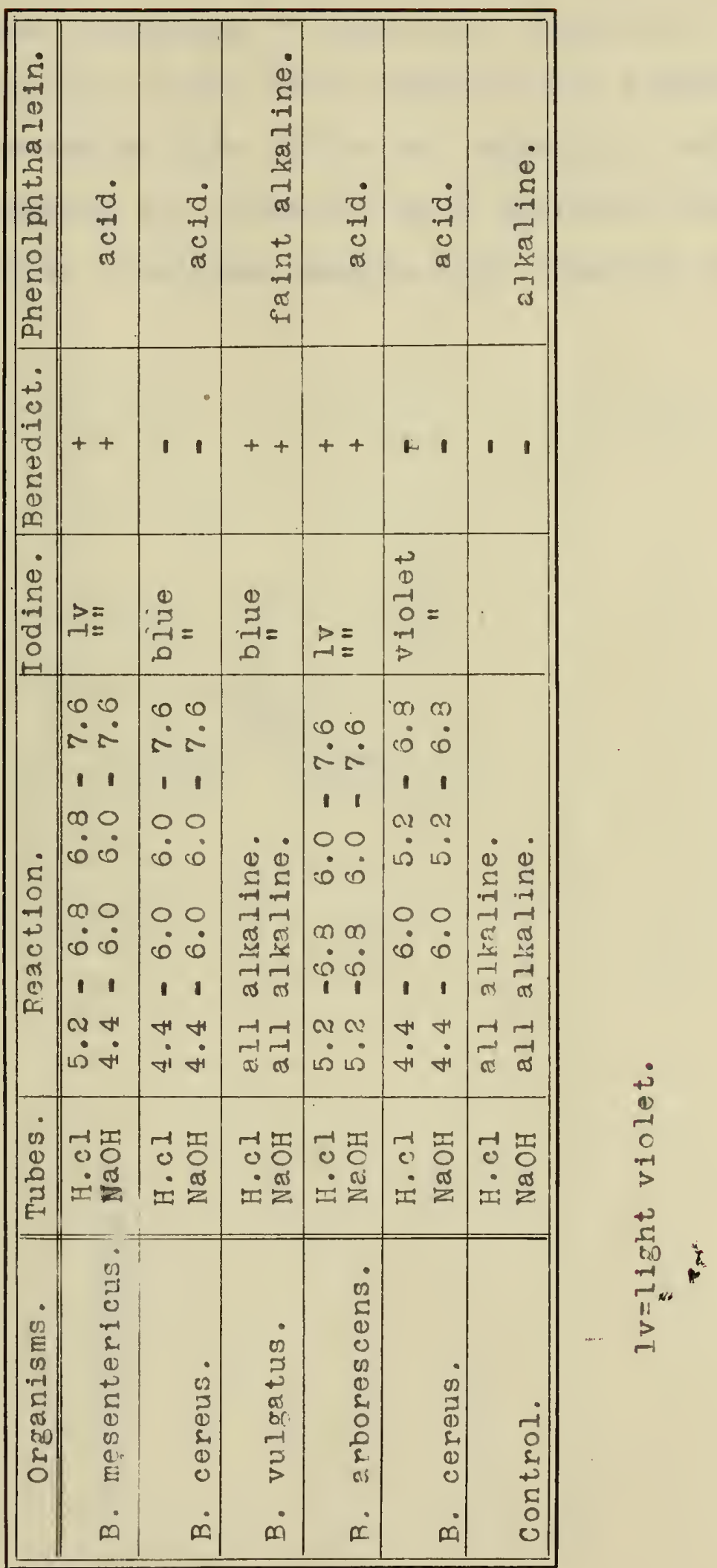



F. Edson and Carpenter's (1912) Method was then tried. F1ro c.c. of $1 \%$ starch paste containing $2 \%$ thymol was added to $5 \mathrm{c} . \mathrm{c}$. of broth cultures of each of the test organisms and incubated over night at $37^{\circ} \mathrm{C}$ and tested with Iodine and Benedict's Solution. Only one organism (B. vulgatus) gave positive results with Benedict's Solution. The same results were obtained on repeating the experiment. 

Table IX.- Diastasic Action According to Edson and Carpenter's Method, When Tested with Iodine and with Renedict's solution.

\begin{tabular}{|l|c|c|}
\hline Organisms. & Iodine. & Benedict. \\
\hline B. mesentericus. & purple. & - \\
\hline B. cereus. & Iight purple. & - \\
B. vulgatus. & clear. & ++ \\
\hline B. arborescens. & Iight purple. & - \\
\hline B. subtilis. & trace of pink. & + \\
\hline Control. & purple. & - \\
\hline
\end{tabular}



Waksman's starch agar plates were prepared, streaked, incubated and tested as with former plates. This agar contains to a liter, $1 \mathrm{gm}$. $\mathrm{K}_{2} \mathrm{HPO}_{4}, 0.5 \mathrm{gm} . \mathrm{MgSO}_{4}, 0.5 \mathrm{gm}$. $\mathrm{Kcl}, 0.01 \mathrm{gm}$. $\mathrm{FeSO}_{4}$, $2 \mathrm{gm}$. $\mathrm{NaNO}_{3}$, and $10 \mathrm{gm}$. of starch. On these plates the growth seldom exceeded $1 \mathrm{~m} . \mathrm{m}$. in diameter with any of the organisms. The plates were tested on 2,5 and 7 days and the results given in Table Xa.

Waksman's tube method was used also. In this, the minerals and $1 \%$ starch bolled in distilled water, were diluted to I liter, tubed 10 c.c. to a tube, sterilized, inoculated, incubated, and tested with Iodine, and with Benedict's Solution for sugar. A control tube was used to check the height of starch in the tubes as an indication of liquefaction of the starch. As shown in Table Xb B. vulgatus was the only one that gave diastaslc action as shown by the helght of starch, by Iodine and by Benedict's Solution. 



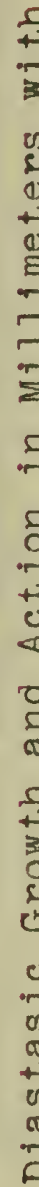

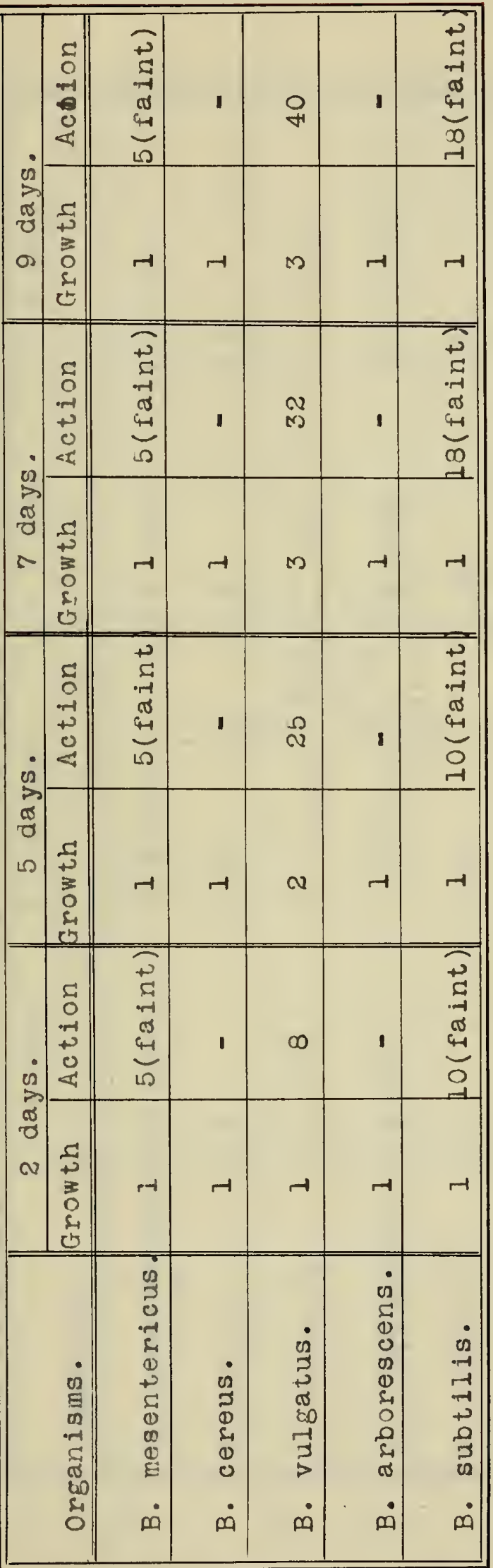



D

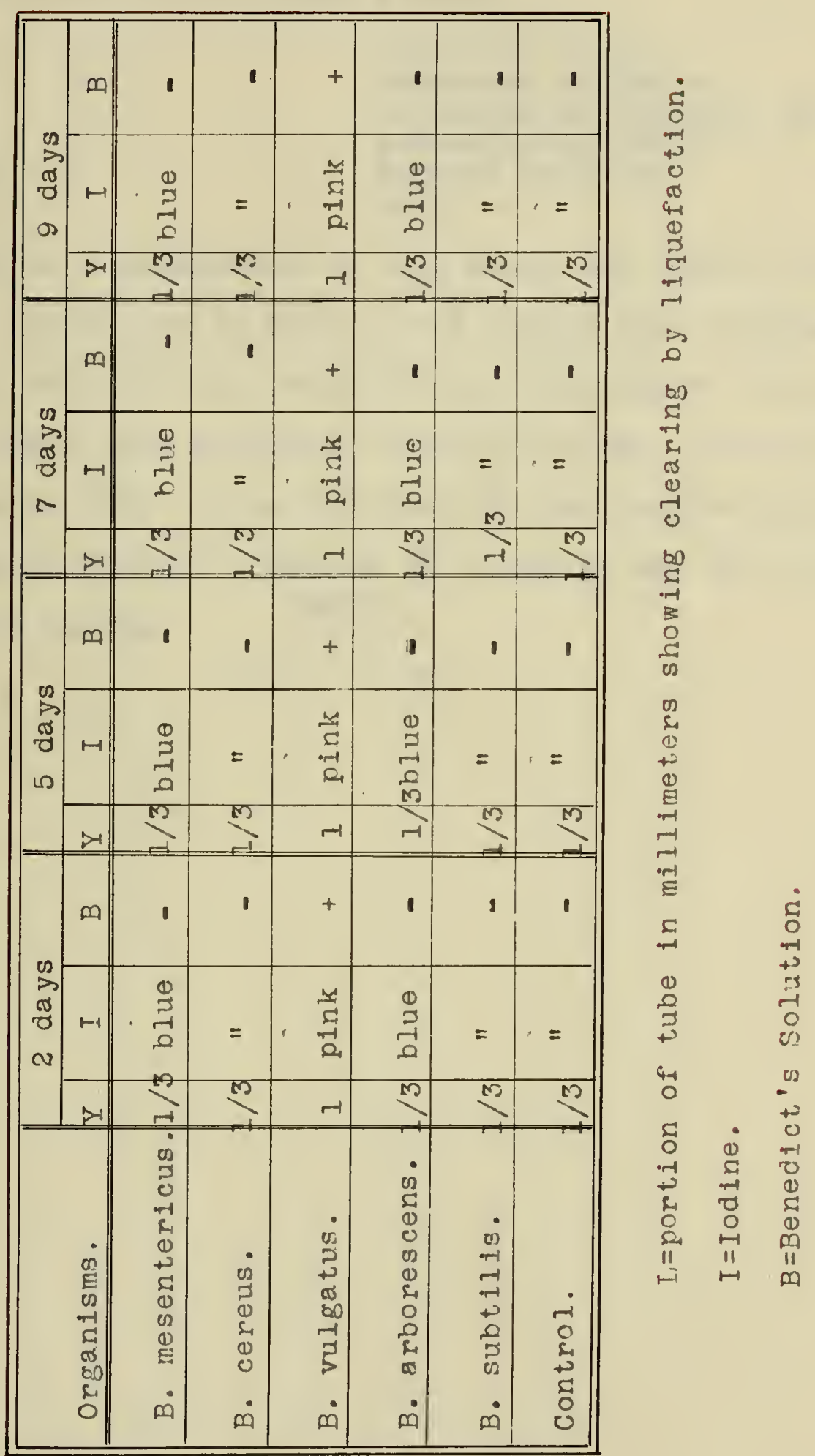



Plates were then made according to Crabill and Reed's Method. This media contained the following forkula:

$\begin{array}{cll}1000 & c c . & \text { distilled water. } \\ 0.5 & \mathrm{gm} . & \text { magnesium sulphate. } \\ 1.0 & " 1 & \text { di-potassium hydrogen phosphate. } \\ 0.5 & " & \text { potassium chloride. } \\ 0.01 & " & \text { ferrous sulphate. } \\ 20.0 & \text { agar. }\end{array}$

The starch in a suspension of cold water was added to the filtered agar, sterilized in flasks, and poured with frequent shaking into steril petri dishes, hardened and streaked as the previous plates were. These were incubated at $37^{\circ} \mathrm{C}$ for two, six and ten days, then flooded with Iodine solution and the results given in Table XI, As with Waksman's Nethod, B. vulgatus was the only organism that gave action. 


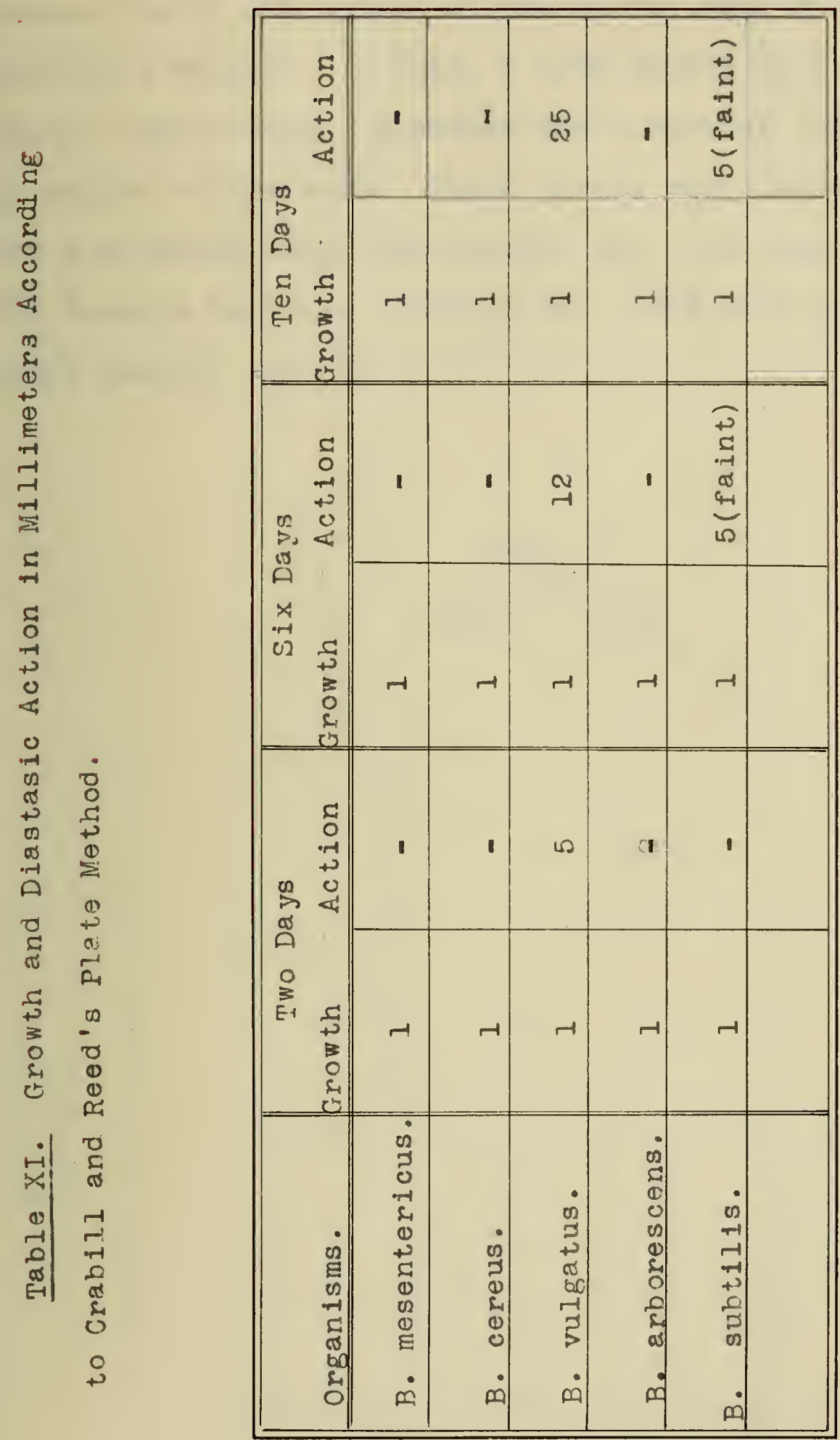

An attempt was made to determine the efficiency of the spot inoculation in the center of the starch agar plate as compared to the streak method. In this, $11 / 2 \%$ starch agar was poured into sterile petri dishes, hardened and a spot of inoculation placed on the center of the agar. These plates were inverted, incubated at $37^{\circ} \mathrm{C}$ and tested with Iodine after one, two, five and seven days with results as given in Table XII. The growths resulting were almost perfect circles. 


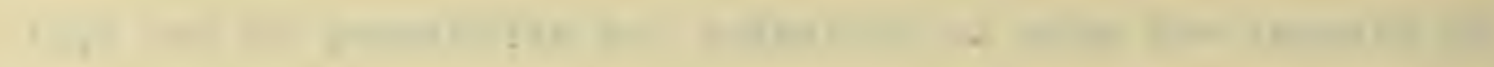

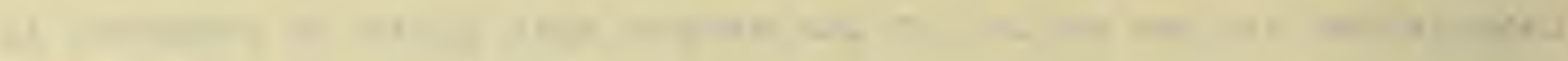

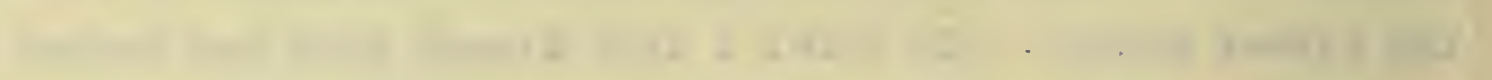

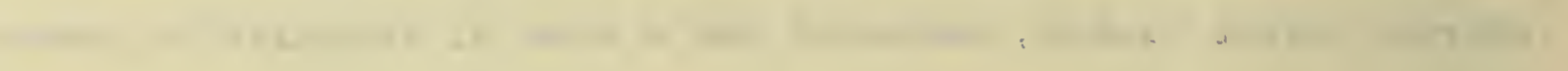

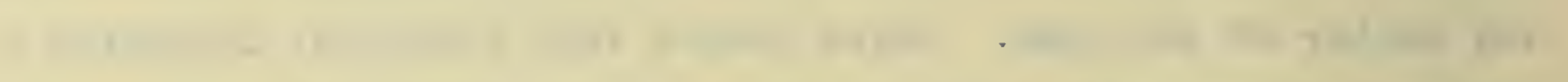

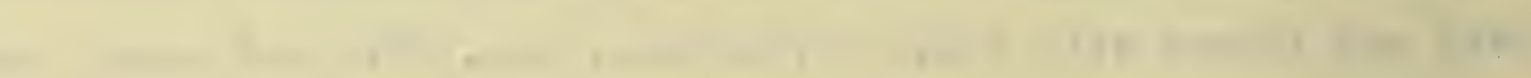

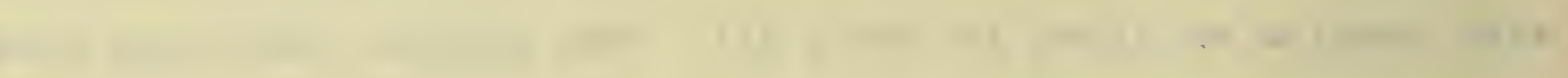

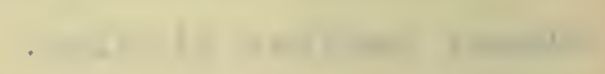




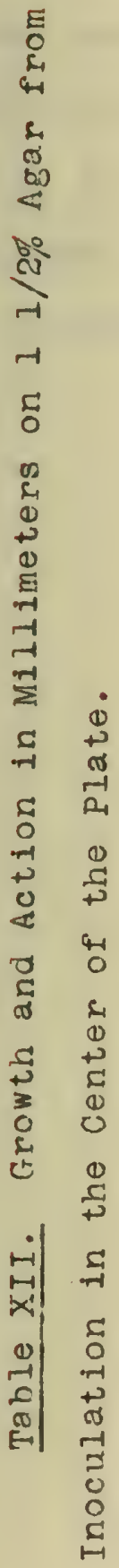

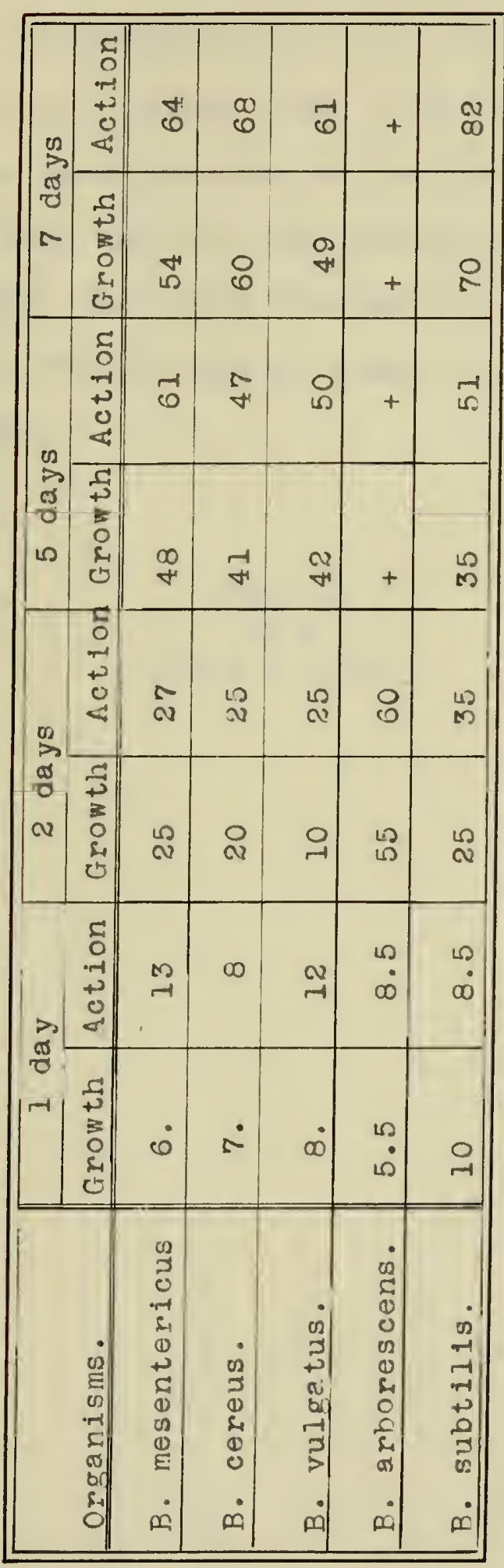



Since peptone is a food for growth, an attempt was made to determine the effect of varying the amount in the starch agar. Starch agar plates containing $1 \%$ starch were made with varying amounts of peptone as follows: $0.2 \%, 0.4 \%, 0.6 \%, 0.8 \%$ and $1.0 \%$. These starch plates were prepared as the former ones were, and inoculation made by both the dot and streak method. After incubation for 2,5 , and 7 days, they were flooded with Iodine and the results in tables. The dot method gave an almost perfect circle of growth and diastasic action. 



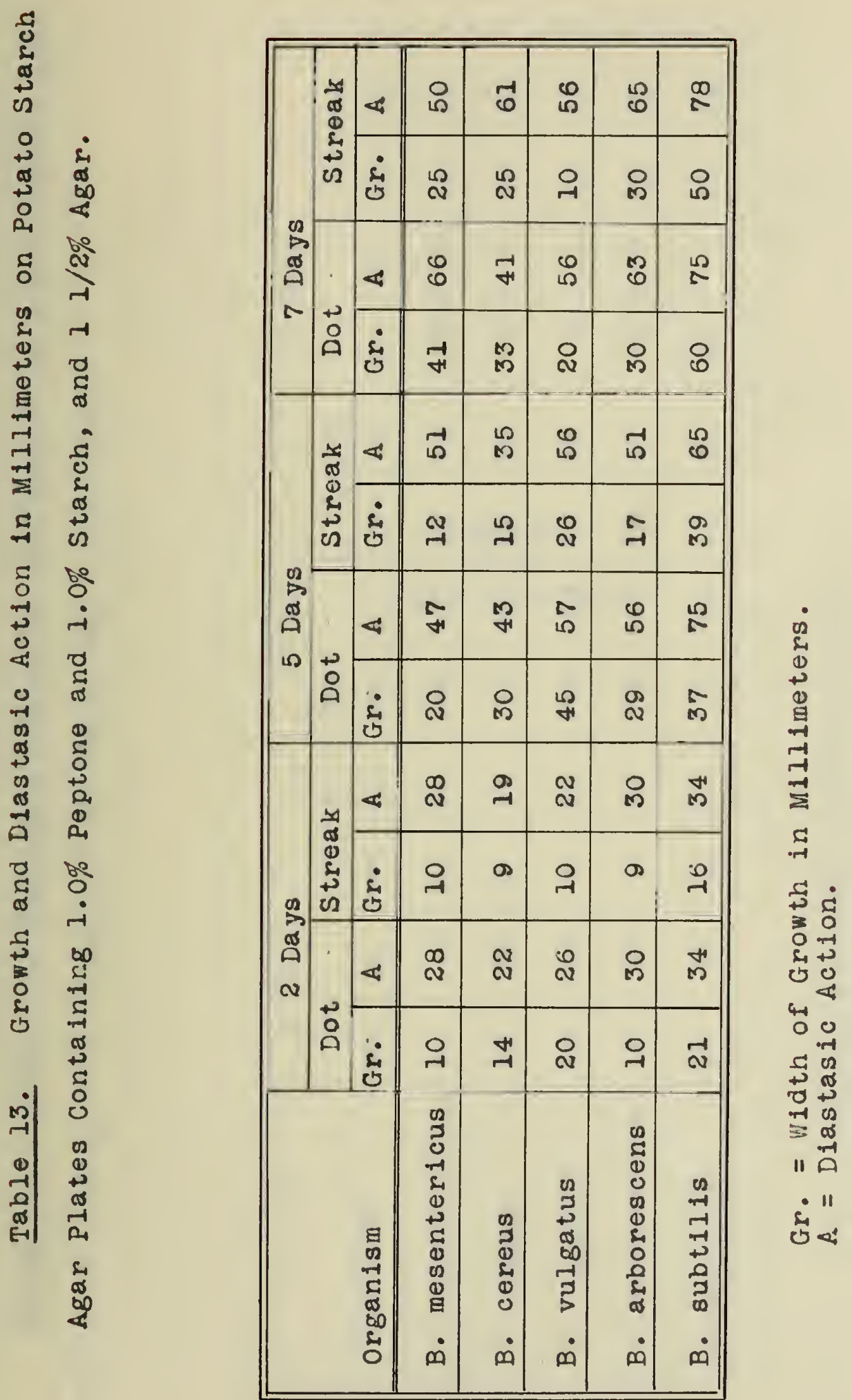





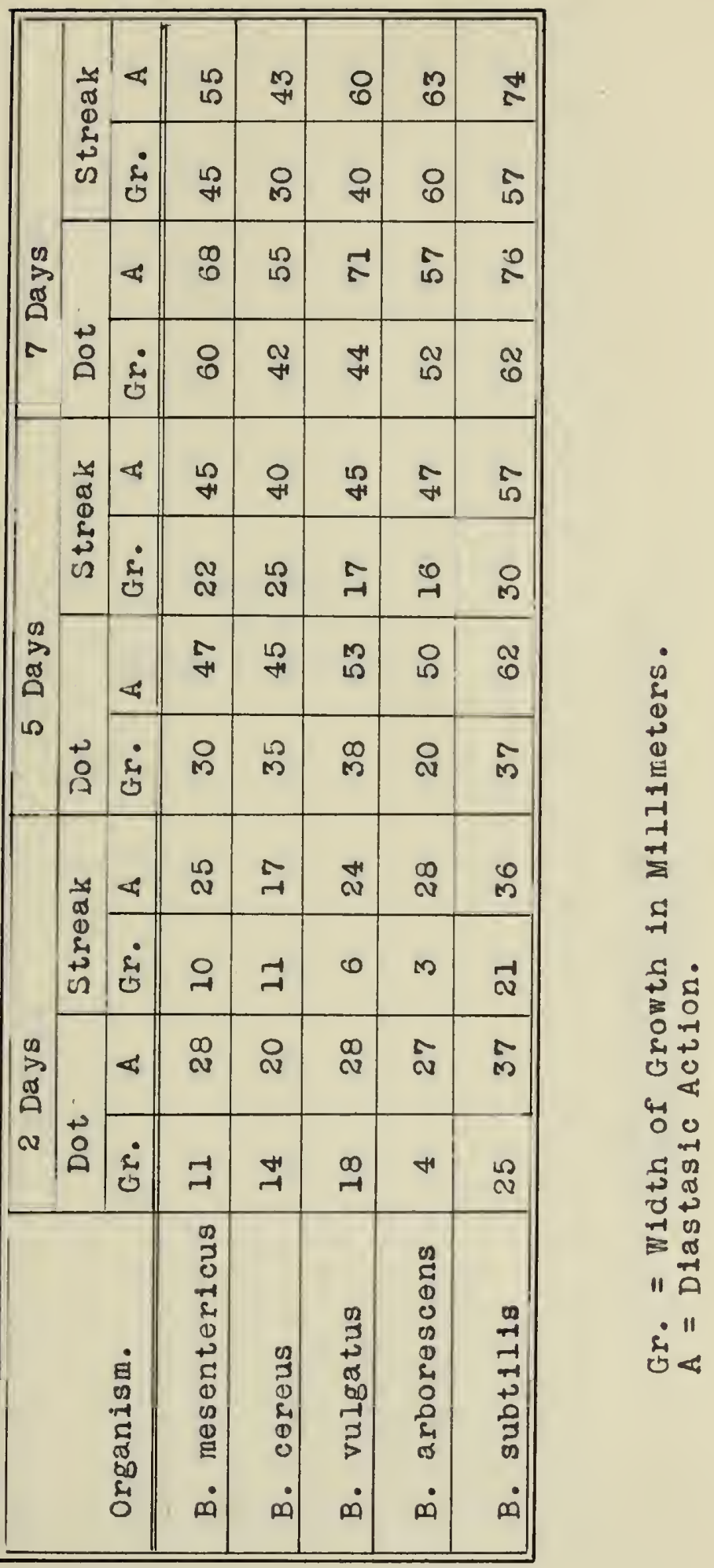





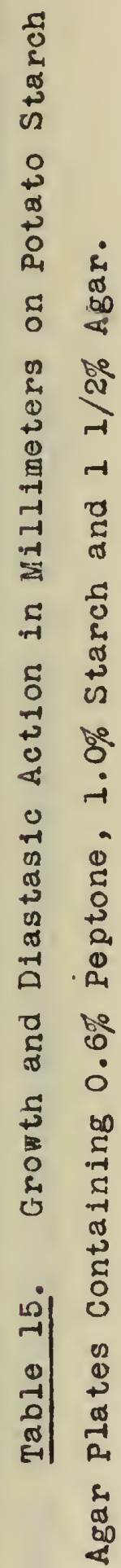

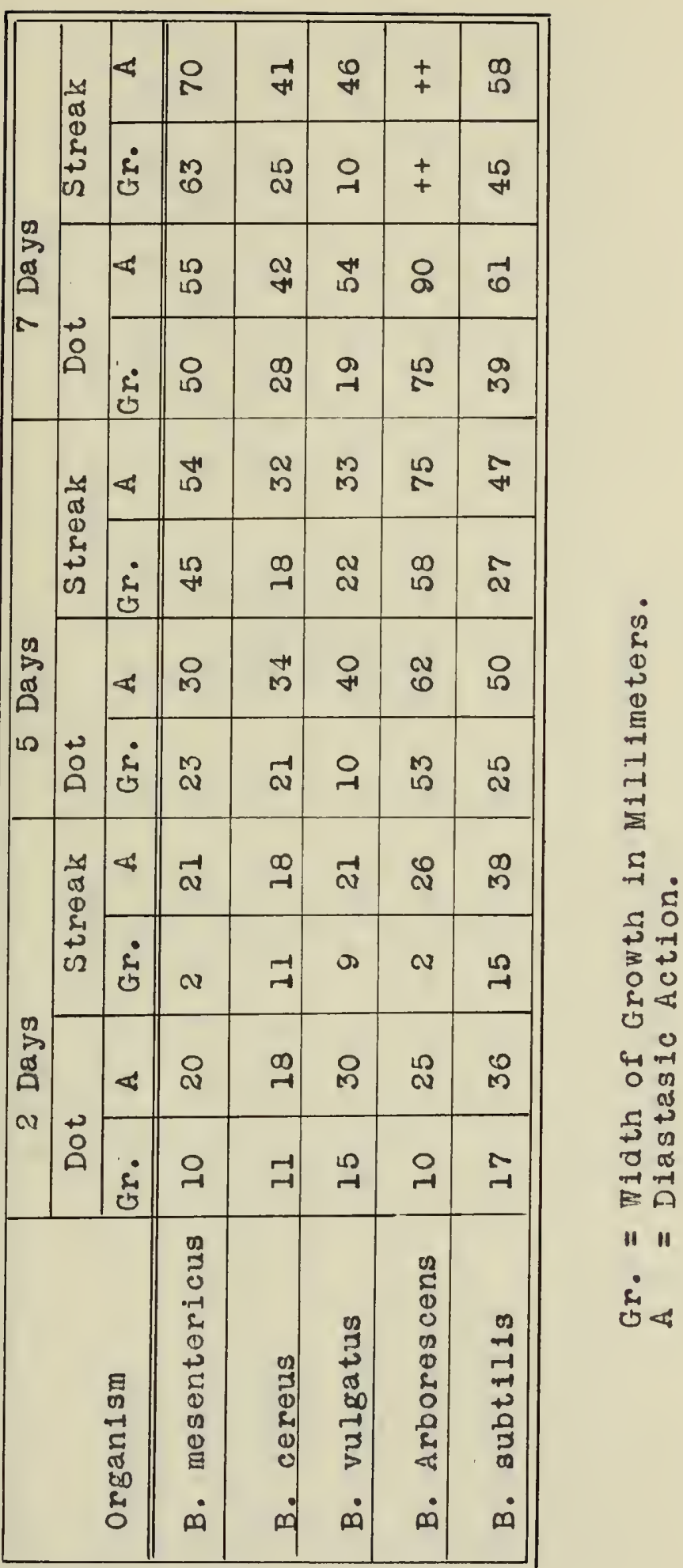





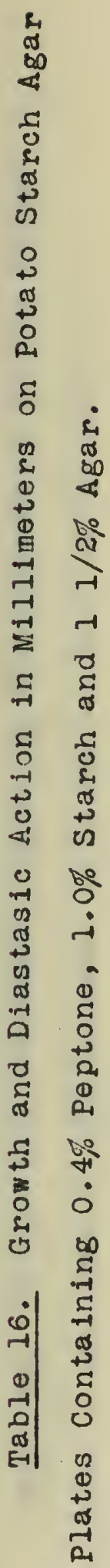

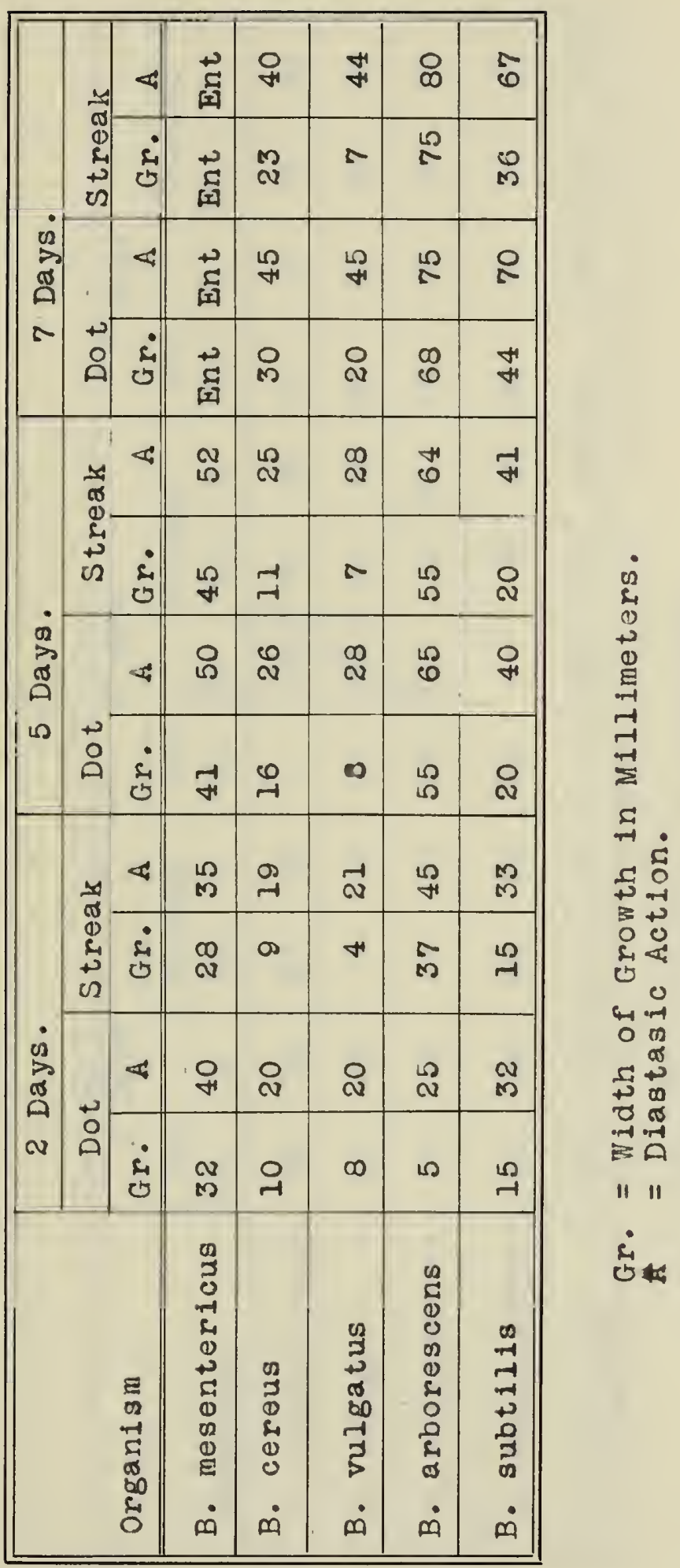



。

$+$

ปี

द \&

a ล

क

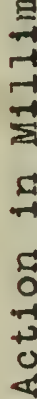

(

of

क

ช

คै Ar

สั ญั

द

言 壳

ن

\begin{tabular}{|c|c|c|c|c|c|c|c|}
\hline \multirow{4}{*}{ 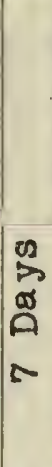 } & \multirow{2}{*}{ 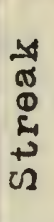 } & 4 & $\underset{\infty}{ }$ & $\stackrel{\infty}{\infty}$ & 요 & $\stackrel{\infty}{\infty}$ & $\stackrel{0}{0}$ \\
\hline & & $\dot{L}$ & $\stackrel{\circ}{\circ}$ & $\stackrel{\infty}{\infty}$ & $\underset{r}{\stackrel{O}{O}}$ & $\stackrel{\circ}{\circ}$ & in \\
\hline & \multirow[b]{2}{*}{$\begin{array}{l}\stackrel{\vec{\circ}}{\circ} \\
\text { }\end{array}$} & 4 & $\stackrel{+}{+}$ & $\mathscr{H}$ & & $\stackrel{\infty}{\infty}$ & 0 \\
\hline & & $\dot{c}$ & $\stackrel{+}{+}$ & D & مُ & ๑ & in \\
\hline \multirow{4}{*}{ 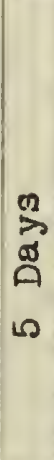 } & \multirow{2}{*}{ 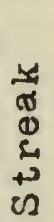 } & $<4$ & $\$$ & $\underset{\infty}{\Phi}$ & $\hat{\text { m }}$ & ஜ & م \\
\hline & & $\dot{8}$ & $\stackrel{\circ}{\Omega}$ & ㅇ & $\infty$ & 8 & $\stackrel{\sim}{\sim}$ \\
\hline & & $<$ & 1 & $\underset{\infty}{\infty}$ & B & + & $\stackrel{\infty}{10}$ \\
\hline & $\begin{array}{l}+ \\
\circ \\
\circ\end{array}$ & i & 1 & $\stackrel{-1}{\omega}$ & $m$ & $\stackrel{0}{\Omega}$ & is \\
\hline \multirow{4}{*}{$\begin{array}{l}\underset{\infty}{\not} \\
\underset{\sigma}{\infty} \\
a \\
v\end{array}$} & \multirow{2}{*}{ 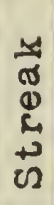 } & $<$ & $\mathscr{m}$ & $\stackrel{\infty}{\rightarrow-1}$ & $\stackrel{-1}{N}$ & مి & 음 \\
\hline & & $\dot{\text { i }}$ & $\stackrel{5}{M}$ & $\tau$ & o & $\begin{array}{l}0 \\
10\end{array}$ & $\stackrel{0}{\circ}$ \\
\hline & \multirow[b]{2}{*}{$\stackrel{\leftrightarrow}{\circ}$} & 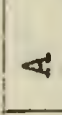 & $\begin{array}{l}\infty \\
m\end{array}$ & ㅇ & $\stackrel{\oplus}{\oplus}$ & 8 & $\stackrel{v}{M}$ \\
\hline & & $\dot{i}$ & $\stackrel{N}{N}$ & $\stackrel{\circ}{\circ}$ & $m$ & م) & $\vec{H}$ \\
\hline & & 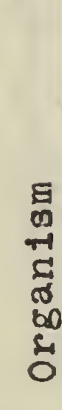 & 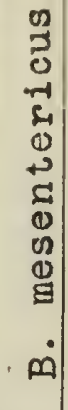 & 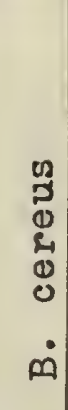 & 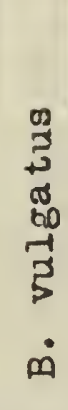 & 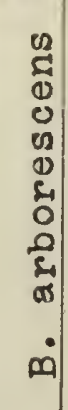 & $\begin{array}{l}n \\
n-1 \\
-1 \\
-1 \\
+1 \\
0 \\
0 \\
0 \\
0\end{array}$ \\
\hline
\end{tabular}





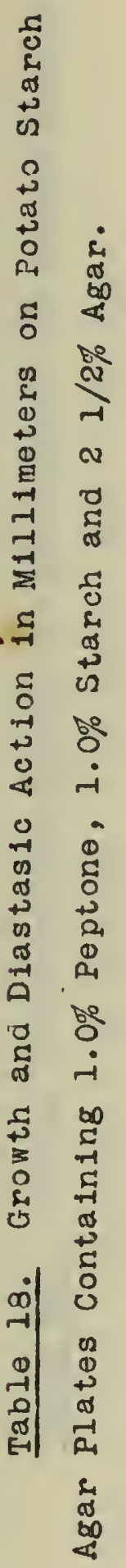

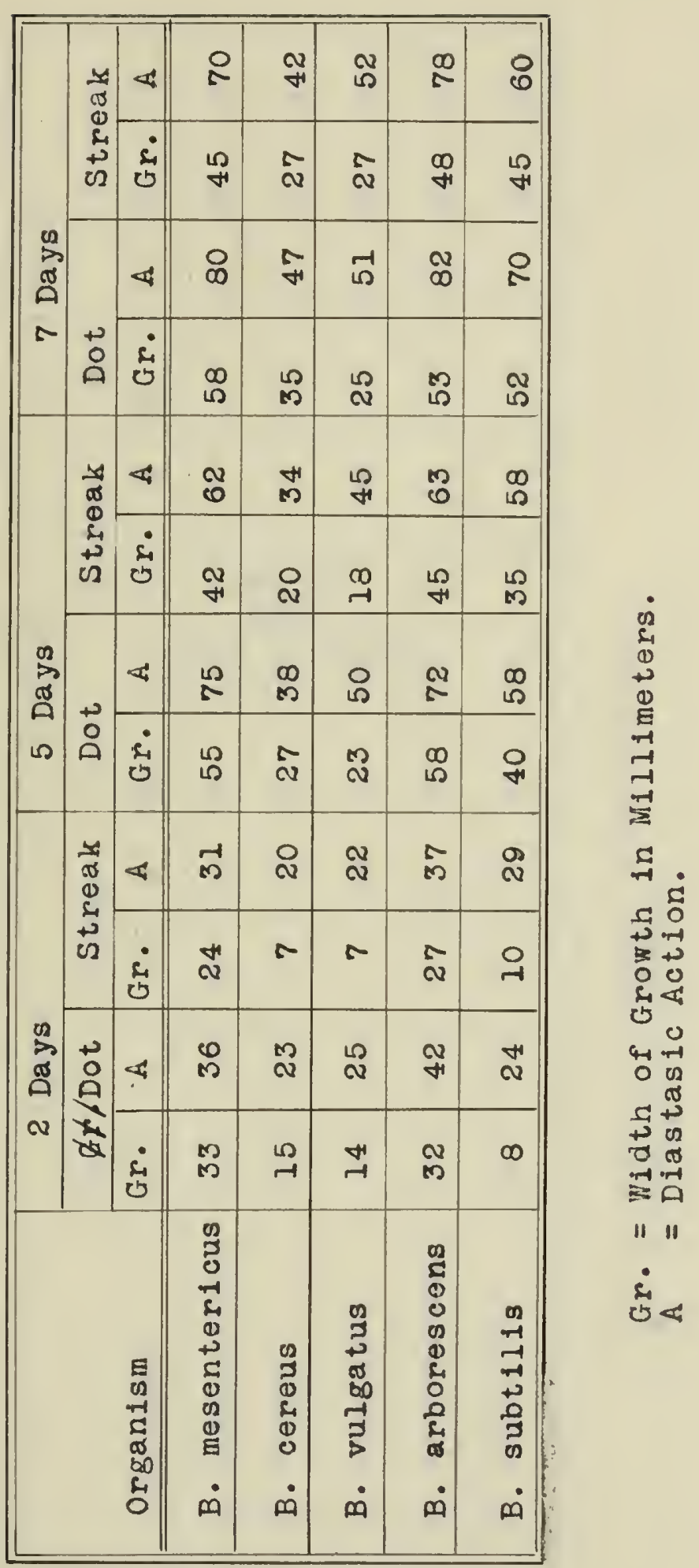





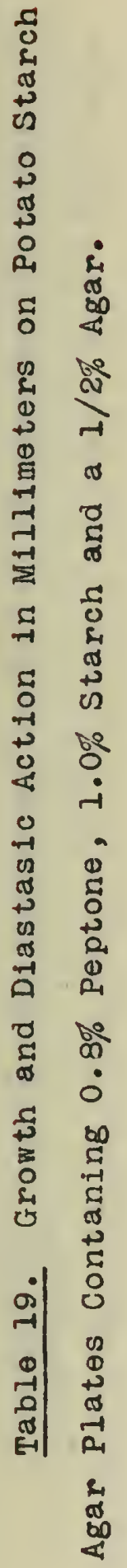

\begin{tabular}{|c|c|c|c|c|c|c|c|c|}
\hline \multirow{4}{*}{$\begin{array}{l}\vec{\sigma} \\
\vec{a} \\
\sim\end{array}$} & \multirow{2}{*}{ 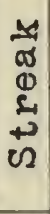 } & 4 & $\stackrel{0}{0}$ & $m$ & $\stackrel{20}{4}$ & $\stackrel{\infty}{\infty}$ & ס & \\
\hline & & $\dot{B}$ & $\begin{array}{l}0 \\
0\end{array}$ & $\stackrel{\sim}{\sim}$ & @ & مَ & $M$ & \\
\hline & \multirow{2}{*}{$\begin{array}{l}+3 \\
0 \\
0\end{array}$} & $<$ & $\stackrel{1}{\infty}$ & $\stackrel{M}{H}$ & $\begin{array}{l}0 \\
10\end{array}$ & $\stackrel{\Omega}{\alpha}$ & & \\
\hline & & $\dot{0}$ & $\stackrel{\infty}{\sigma}$ & DO & $\stackrel{m}{\infty}$ & ષే & $\stackrel{10}{M}$ & \\
\hline \multirow{4}{*}{$\begin{array}{l}\stackrel{\infty}{0} \\
\overrightarrow{0} \\
0\end{array}$} & \multirow{2}{*}{ 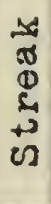 } & 4 & $\widetilde{0}$ & $\begin{array}{l}\infty \\
\mathbb{N}\end{array}$ & $\stackrel{\rho}{m}$ & $\begin{array}{l}4 \\
15\end{array}$ & م 10 & \\
\hline & & $\dot{0}$ & 5 & 虽 & 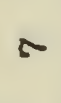 & $\stackrel{H}{H}$ & డ) & * \\
\hline & \multirow[b]{2}{*}{$\stackrel{+}{\circ}$} & 4 & $\stackrel{N}{\Sigma}$ & $\stackrel{0}{m}$ & $\stackrel{0}{*}$ & $\begin{array}{l}\infty \\
0 \\
0\end{array}$ & م & $\begin{array}{l}4 \\
0 \\
0 \\
01\end{array}$ \\
\hline & & $\dot{i}$ & ס & น & $\stackrel{0}{-1}$ & 8 & $\begin{array}{l}\infty \\
\sim\end{array}$ & $\underset{-1}{-1}$ \\
\hline \multirow{4}{*}{$\begin{array}{l}\infty \\
\nabla \\
\infty \\
\infty \\
\sim\end{array}$} & \multirow{2}{*}{ 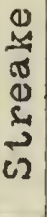 } & $<$ & $\stackrel{1}{\infty}$ & $\stackrel{0}{-1}$ & $\stackrel{0}{-1}$ & 5 & 8 & $\stackrel{5}{\Rightarrow}$ \\
\hline & & $\dot{c}$ & $\stackrel{+1}{+1}$ & $\stackrel{0}{1}$ & ת) & $\stackrel{\sim}{\sim}$ & $M$ & $\begin{array}{l}\overrightarrow{1}+1 \\
30 \\
0\end{array}$ \\
\hline & \multirow[b]{2}{*}{$\stackrel{+}{\circ}$} & $<$ & $\begin{array}{l}\infty \\
\infty\end{array}$ & $\stackrel{8}{\mathrm{~N}}$ & 요 & $\begin{array}{l}\infty \\
\omega\end{array}$ & 옹 & 40 \\
\hline & & $\dot{c}$ & $M$ & 10 & a & $\stackrel{0}{\Omega}$ & $\stackrel{+}{4}$ & \begin{tabular}{ll} 
& \multicolumn{1}{c}{+0} \\
0 & 0 \\
0 & $\alpha$ \\
-1 & 0
\end{tabular} \\
\hline & & 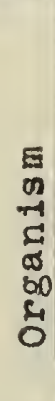 & 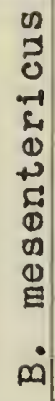 & $\begin{array}{l}\text { J2 } \\
\text { వ } \\
0 \\
\text { \& } \\
0 \\
0 \\
\text { வ }\end{array}$ & 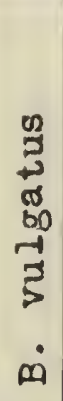 & 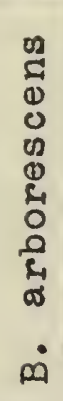 & $\begin{array}{l}02 \\
\text { an } \\
+1 \\
0-1 \\
+0 \\
0 \\
0 \\
01 \\
0 \\
0\end{array}$ & $\begin{array}{l}\| 11 \\
\dot{0}<4\end{array}$ \\
\hline
\end{tabular}





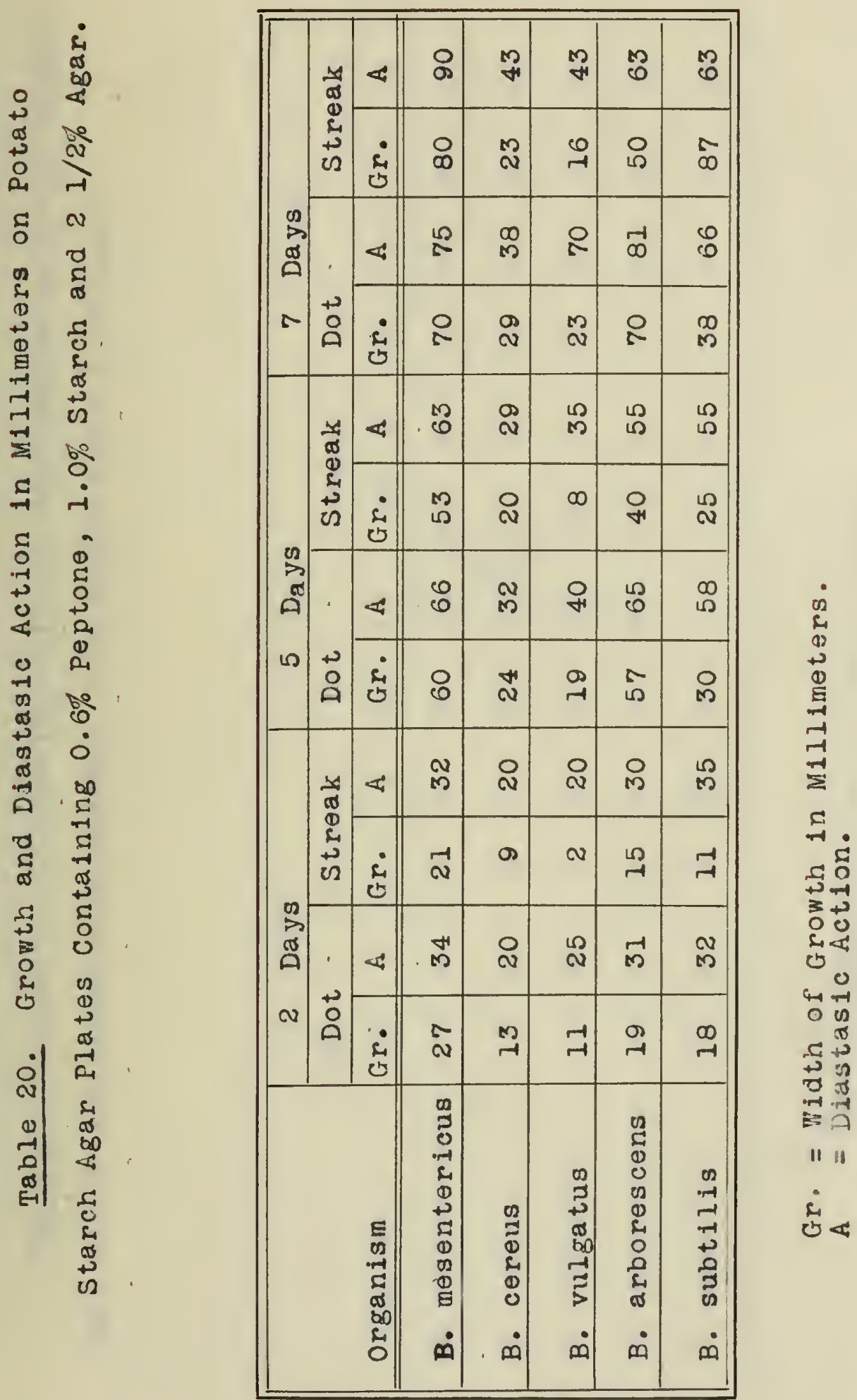





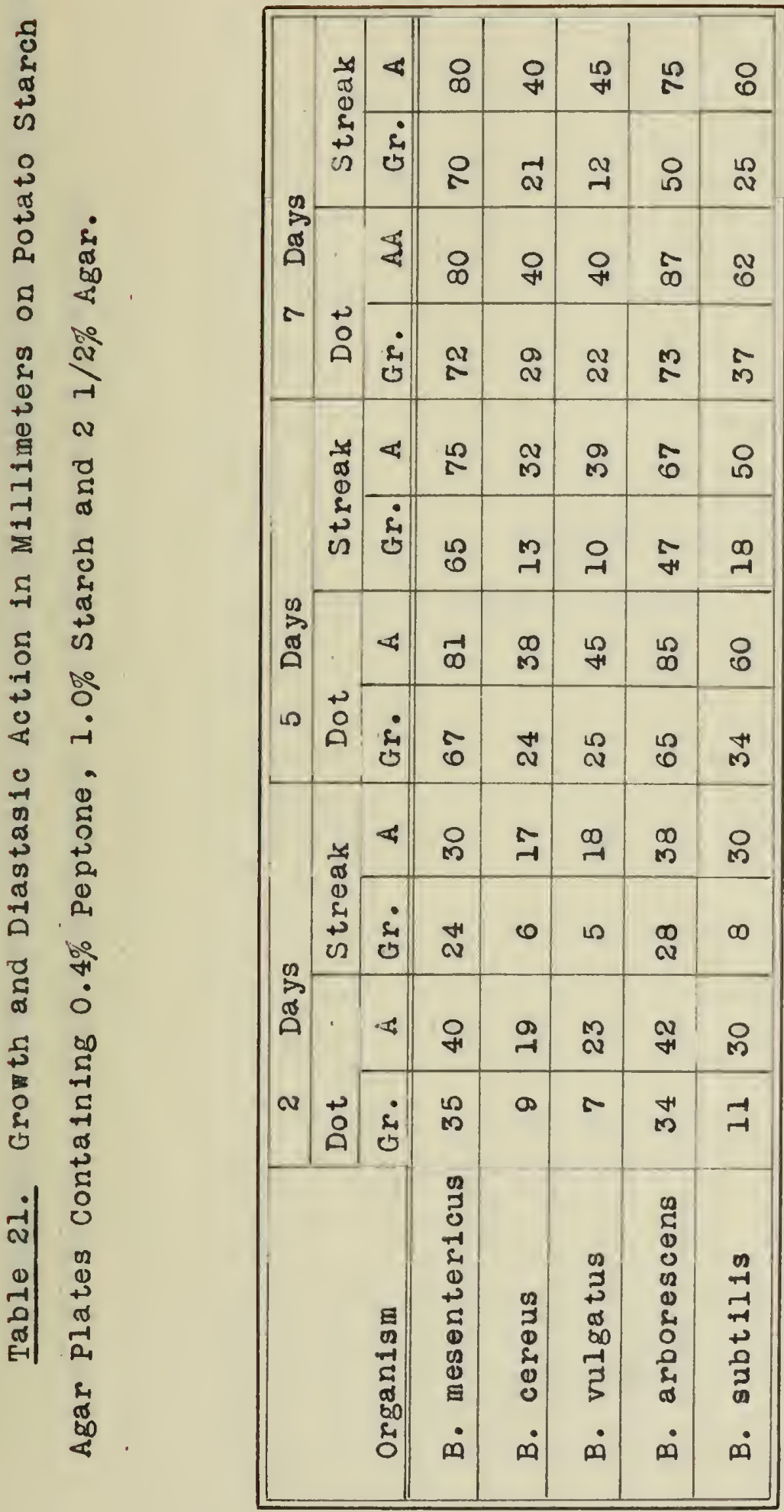




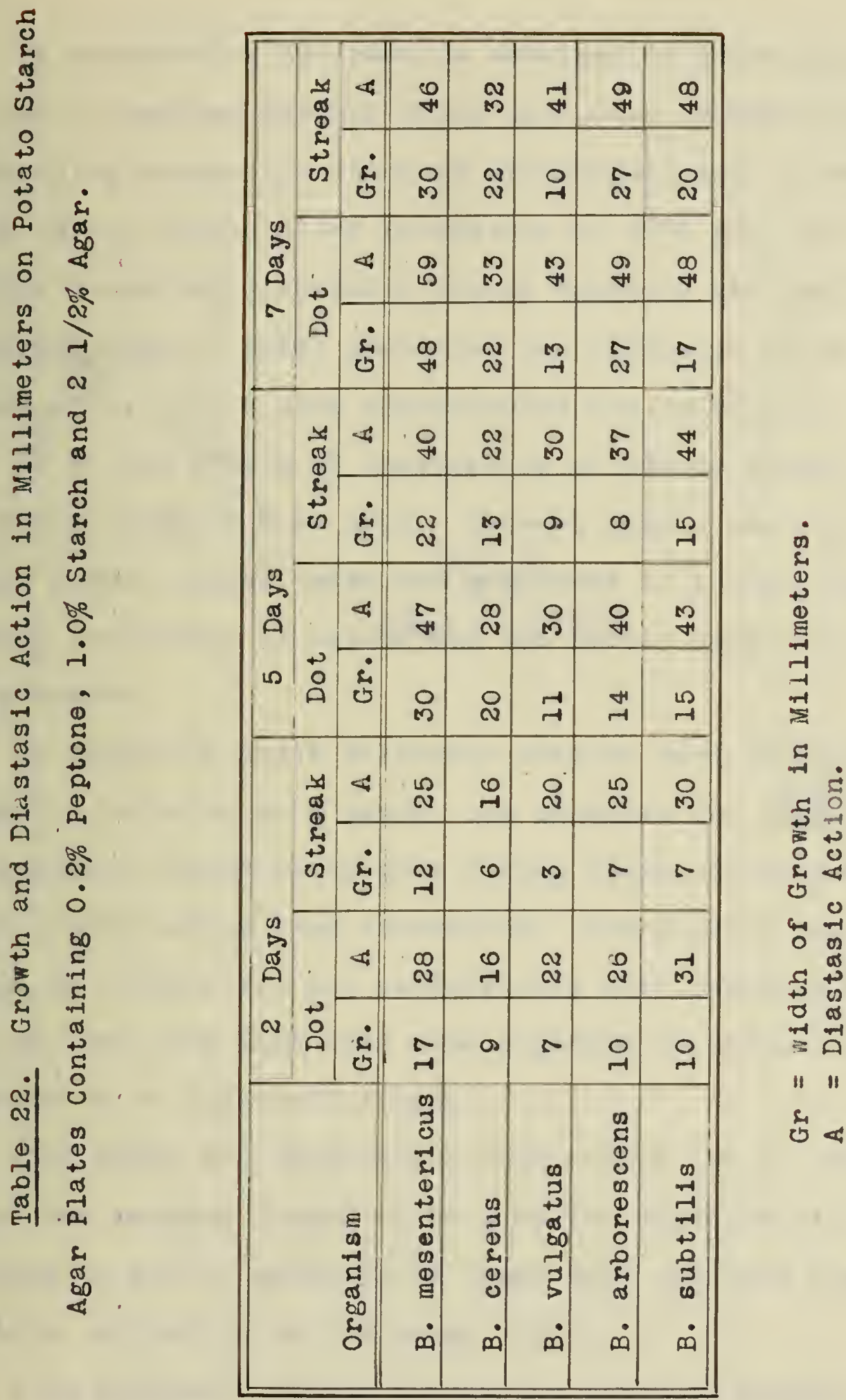



\section{Discussion.}

In considering the results obtained in these experiments on the use of various methods which have been proposed in the past for determining diastasic action of microörganisms, it was found that $1 \%$ of potato starch after incubation at $37^{\circ} \mathrm{C}$ gave the best results. Smaller percentages showed a rather complete utilization of starch. A heavier agar $(21 / 2 \%)$ prevented the diffusion of the enzyme and consequently gave a more concentrated action within a limited area.

As to the method of inoculation of starch plates both the dot and streak methods were used. Several points may be given in favor of the former method: ease and quickness of inoculation, ease of getting the radius of action and the better applicability to the group number.

In synthetic media different results were obtained. With Frankel's solution as a basis, one organism (B. cereus) which on the ordinary starch plate gave strong diastasic action gave no action except after long incubation. Uschinsky's Protein Free Medium as a basis was not satisfactory with percents of starch lower than $1 \%$, and even then this same organism (B.cereus) remained negative as to diastasic action.

With Edson and Carpenter's tube method the $2 \%$ thymol evidently killed the enzymes formed as well as the organism with all except B. vulgatus and B. subtilis as these were the only ones which gave positive indication of diastasic action.

With Waksman's starch plates the width of growth of the organisms was greatly reduced and here only one organism (B.vulgatus) 

gave positive diastasic action. The plate and tube method checked as to the action taking place.

The results with Crabill and Reed's method in which starch is the only source of carbon and in which there is no protein material for food for the organisms, the results showed that $B$. vulgatus was the only organism which gave positive action.

The whole question seems to be the point of getting an equilibrium between the amount of starch, the amount of enzyme, and the time. The main variations in the experiments were starch and time and enzyme, the variation in agar and peptone being practically a variation in enzyme. 

Conclusion.

With lower percentages of $\operatorname{starch}(.010, .015, .020$ and $.025 \%)$ in $11 / 2 \%$ agar the amount of starch present did not give satisfactory results--the diastasic action with Iodine being hard to distinguish. The best results were obtained between $0.5 \%$ and $2.0 \%$ of starch showing that this amount probably furnished the proper concentration of starch to be attacked by the enzyme.

The amount of agar used has an effect upon the diffusibility and consequent action of the diastasic enzyme. With heavier agar (2 $1 / 2 \%$ ) the growth was not as extensive as with $11 / 2 \%$ but the diastasic action was more distinct showing that the heavier agar probably prevented the diffusion of the enzyme thus causing the action to be confined within narrower limits. One per cent of starch seemed to give the best results.

The length of incubation period is an important factor in the diastasic action of enzymes. The amount of starch used seems to depend upon the period of incubation--lower percents being better for the shorter period.

Different starches have an effect in the action of diastasic enzymes on the starch agar plates. The starches studied range in action from strongest to the weakest as follows: potato starch, arrowroot, pea, corn, wheat, oat, and rice. 

A study of diastasic action in synthetic media showed variability in the different organisms as to the production of diastase.

W1th starch broth, one per cent of starch gave the best results. The time element, however, is probably a factor.

Waksman's plate and tube method, and Crabill and Reed's plate method, as tested with the five organisms, gave positive diastasic action with only one organism. (B. vulgatus). Edson and Carpenter's tube method gave positive action with two organisms (B. vulgatus and $B$. subtilis).

Variation in the amount of peptone used apparently had no influence on the amount of growth. 

Acknowledgment.

All of the work reported in this paper was done while the author held an assistantship in the Bacteriology vepartment of the University of 111 inois. The study was outlined by Dr. F. F. Tanner and it is a pleasure to acknowledge his advice and assistance given throughout the work. 

Abelous and Heim. 1892. Note sur l'existence de ferments digestef dans les oeufs de crustacees. Comp. Rend. Soc. Biol. 3 (1892) 273.

Adler, G. 1916. Influence of the Hydrogen Ion on the Activity of malt Diastase. Biochemical Bulletin 77 (1916) 15-17.

Allen, P., 1918. A Simple Method for the Classification of Bacteria as to Diastase Formation. Jour. Bact. 3, 15-17.

Ando, F., 1912. The Saccharification of Starch by Koji Diastases in the Presence of Acids and Salts. Orig. Comm. 8th. Intern. Cong. Appl. Chem. 14, 13-24.

Ascoli and Bonfanti. 1904. Zeit. Physiologische Chemie 43, 156 Baranetsky. 1373. Starkeumbilden Fermente.

Barnett, G. D. and Chapman, H. S., 1918. Colorimetric Determination of Reaction of Bacteriologic Mediums and other Fluids. Jour. Amer. Med Assn. 70, 1062

Beijerinck, M. W. 1395. Cent. Bakt. Abt. II. 1, 221; Abt. I. $6,(1385) 44-48$.

Bial. 1894. Ueber die Beziehungen des diastatischen Ferments des Blutes und der lymphe zur Zuckerbildung in der Leber. Pfugler's Archives 55, 434.

Biltz, W. B. 1913. Diastasic Starch Decomposition. Berichte der Deut. Chem. Cesellsch. 46, 1532-1536.

Bouchardat and Sandras. 1845. Des Functions du Pancreas et de son Influence dans la Digestion des feculents. Compt. Rend. 20, 1085.

Boudourf. 1899. Recherches sur 12 Valeur Physlologique des Tubes Puloriques de quelques Teleosteens. Comp. Rend. $128,745$.

Brasse. 1884. Sur la Presence de l'Amylase dans les F'euilles. Compt. Rend. 99, 878.

Brown, H. T. and Heron, J., 1879. Contributions to the History of Starch and Its Transformations. Jour. Chem Soc. Trans. 1879, 596; Ann. Chem. 99, 165. 

Brown and Miller. 1899. Jour. Chem Soc. 75, 333.

Brown, H. T. and Morris, J. H. 1885. Ann. Chem. 231, 172 ; The Non-Crystallizable Products of the Action of Diastase on Starch. Jour. Chem. Soc. $47,527$.

Brown and Morris. 1893. Jour. Chem. Soc. 63, 604.

Brown and Morris. 1890. On the Germination of Some of the Gramineae. Jour. Chem. Soc. Trans. 1890. 458.

Brown, Morris and Röhman. 1894. Chem. Ber. 27, 3251.

Brücke, E. 1872. Studein über die Kohlehydrate und über die art uie sie verdaut und aufgesaugt werden. wien. Acad. Ber. 1165,126 .

Brunton, Lauder and MacFadyen. 1889. The Ferment Action of Bacter1a. Proc.-Roy. Soc. 46, 542.

Butkewitsch, 1908. Biochem. Ze1t.10, 314.

Cavazzani, Emil. 1893. Zur Kenntnis der Diastatischer Wirkung der Bakterien. Centbl. Bakt. Abt. 1, Bd. 13, 587-589.

Cohnheim. 1912. Enzymes. John Wiley \& Sons. New York.

Crabill, C. H. and Reed, H. S. 1915. Convenient Nethods for Demonstrating the Biochemical Activity of Microorganisms with Special Reference to the Production and Activity of Enzymes. Biochem. Bulletin. 4.

Chrzosoz. 1808. Zeitscho f. Spiritusind. 31, 52.

De Bary. 1858. Ueber die Myxomyceten. Bot. Zeit. 16, 357.

Dubrunfaut. 1823. Ueber Verwanderung des Stärkemehls in Zucker durch Malz. Erdn. Jour. Tech. Chem. 9, 156.

Edson, H. A. and Carpenter, C. W., 1912. The Green Fluorescent Bacteria occurring in Maple Sap. Vermont Ag. Fxp. Sta. Ru11. 167.

Effront, J. 1912. Amylase. Enzymes and their Application. London.

Effront, J. and Prescott, S. C. 1917. Biocherical Catalysts in If $\theta$ and Industry. John Tiley and Sons, Inc., New York.

Ehrlich, E. 1916. Saccharification of Gelatinized Barley. Allgem. Brau. Hopfer. Ztg. 56, 527-528

Euler, H., and Pope, T. H. 1912. General Chemistry of the Enzymes. John Wiley and Sons, Inc. New York. 

Fermi, claudio. 1890. I fermenti peptici e diastasici dei Microbi. In Giov. R. Acad. Med. Torino. 1-z.

Fernbach, A. and Wolff, J. 1907. The Saccharification of Soluble Starch by Barley Extract. Comp. Rend. 145 , The Action of Barley Extract upon Natural Starch and Artificial Starch. Comp. Rend. 1, 645-46.

Foster. 1867. Notes on Amylolytic Ferments. Jour. of Anatomy and Physiology. 1, 107.

Fredericq. 1878. La Digestion des Matieres Albuminoides chez Quelques invertebres. Arch. de Zool. Experimentale. $7, \quad 39$.

Green, J. R. 1901. The Soluble Ferments and Fermentation. Cambridge.

Gomp-Besanez. 1874. Ueber das Vorkommen eines Diastatischen und Peptonisirenden Fermentes in den Wickensamen.

Bev. d. Deut. Chem. Gesell. 7, 1478.

Griessmeyer, V. 1871. Ueber das Verhalten von Stärke und Dextrin Gegen Jod und Gerbsäure. Liebig's finnalen der Chem. u Pharm. 160 , 40.

Hale. 1902. School of Mines Quarterly. 24, 125.

Hamburger. 1895. Vergleichende Untersuchung über die Einwirkung des speichels, des Pancreas und Darmsaftes, sowie des Blutes auf Stärkekleister. Pflüger's Archiv. 60,543 .

Harding, H. A., Morse, W. J. and Jones, I. R. 1909. The Bacterial Soft Rots of Certain Vegetables. N. Y. Agr. Exp. Sta. (Geneva) Tech. Bulletin. 11.

Hawkins, I. H. 1913. The Effect of Certain Chlorides Singly and Combined in Pairs on the Activity of Nalt Diastase. Botan. Gaz. 55, 265-85.

Henri, V. 1902. The General Theory of the Action of Diastases. Compt. Rend. Aced. Sci. (Paris) 135,. No.21, 916-19.

Herzfeld, A. 1879. Berichte 12, 2120. Uéber die Einwirkung der Diastase auf Stärkekeister. Bev. d. Deut. Chem. Gese11. 12, 2120.

Jacoby, M. 1917. Enzyme Formation. Biochem. Zeit. 83, 74-80. Jacoby, M. 1918. The Formation of Enzymes. Biochem. Zeit. 

Johnson, 1898. Jour. Chem. Soc. 73, 490.

Kita, G. 1918. Influence of Calcium Salts on the Starch-Liquefying Enzyme of Aspergillus Oxyzae. Jour. Soc. Chem. Ind.

$38,508 \mathrm{~A}$.

Kirchhoff, 1814. Ueber die Zuckerbildung Beim. Malzen des Getreides. Schweig's Jour. 14, 389.

Kjeldahl, 1879. Mediel fra Charlsberg Laboratoriet. 1.

Kladiaschwili. 1904. J. Russ. Phys. Chem. Soc. 36, 905.

Koch, G. P. 1916. Diastase Activity and Invertase Activity of Bacteria. Soil Science. I, 179-196.

Kohnstamm, P. 1901. Amylolytische Glycosid-spaltende, Proterlytische und Cellulose lösende Fermente in Holybenoknenden Pilzen. Bot. Centbl. Beihefte, Bd. 10, 90-121.

Kosmann. 1877. Recherches Chimiques sur les Fermentes Contenus dans leo Vergentaux. Bull. de la Soc. Chim. de Paris $27,251$.

Krauch. 1879. Beiträge zur Kenntniss der Ungeformten Fermente im Pflanzenreich. Landwirthsch Versuchsstat. 23.

Kuisda, Adolph. 1807. New Work upon the Composition and Saccharification of Starch. Zeit. Oester. Apoth. Vev. 45 , $119-121$.

Lang, S. 1911. Action of Pancreatic Diastase Upon Various Starches. Zeit. Exp. Path. 8, 279.

Lanthrop, A. P., 1911. Chemistry of the cell Intracellular Enzymes. Biochemical Bulletin $1,88$.

Leuchs. 1831. Wirkung des speichels auf Stärke. Poggend. Annal. $22,623$.

Ling. 1910. 7th. Intern. Cong. Appl. Chem. 1, 123.

I.intner, C. J., and Dull, G., 1893. Ueber den Abbau der Stårke unter dem Einfluss der Diastasewirkung. Berichte Deut. Chem. Gesse11. 16, 2533; 23,3060.

Maquenne, "L. and Roux, E., 1907. Diastatic Saccharification of starch. Ann. Chim. Phys. 9, 107-221.

Marsha1l, C. E., Microbiology. P. Blakiston's Son and Co.,

Miahle, 1845. De la Digestion et l'assimilation des matieres sucre et amiloides. Comp. Rend. 20, 954, 1485.

Morris and Wells. Diastase in Yeast. Trans. Instit. Brewing. 6 . 

Müller, E. 1908. The Starch-Paste Plate, a Simple Aid for the study of Diastatic Ferment Action. Med. Klin. Breslau. Centr.

Müller and Masayama. 1900. Ueber ein Diastatisches Ferment im Huhnerei. Zeit. Biol. $39,547$.

Musculus, F. V. and Grueber, D. 1878. Sur 1'Amidon. Bull. Soc. Chim. 30,54 . Compt. Rend. 86, 1459.

Musculus, F. V. 1860. Remarques sur la Transformation de la Matiere Amylacee en Glucose et Dextrine. Compt. Rend. $50,785$.

O'Sullivan, C. 1872. On the Transformation Products of Starch. Jour. Chem. Soc. Trans. 579.

Pauletig, M. 1918. Digestibility of Starches from Various Vegetable Foods by the Diastases from Malt, Pancreas, and Saliva. Jour. Chem. Soc. 112, I, 670.

Payen and Persoz. 1833. Memoire sur la Diastase, les Principaux Products de ses Reactions et leurs. Applications aux arts Industriels. Ann. de ChIm. et. Phys. 53, 73.

Pfeffer. 1896. Ueber die Regulatorische Bildung von Diastase. Bev. d. Math. Phys. Classe d. Kon Sächs Gesell der Wissensch. zu. Leipzig. 513.

Prege1. 1895. Ueber Gewinnung, Eigenschaften, und Wirkungen des Darmsaftes von Schafte. Pfluger's Archiv. 61, 359.

Pringsheim. 1913-1915. Berichte, 14, 2533. Berichte, 47, 2565. Landiv. Vers. Stat. 84, 267. Naturwissenchaften, iii, 95.

Röhmann. 1892. Zur Kenntniss des Diastatischen Fermentes der Lymphe. Pflüger's Archiv. 52, 157.

Saito, K. 1910. The Influence of Food on the Diastase Formation by Molds. Wochṣchr. Brau. 27, 181-3, Chem. Zentr. I, 1738.

Samec, M. and Jenice S. 1915. The Soluble Stârches. Kolloidchem. Beihefte. $7, \quad 137-71$.

Scharlinger, F. 1911. The Formation of Crystallin Polysaccharids (Dextrins) from Starch Paste by Microörganisms. Centr. Bakt. Parasitenk. II, Abt. 29, 188-91. Chem. Absts. 2575.

Sherman, H. C. and Baker, J. C. 1916. Starch às a Sübstrate for Enzyme Action. Jour. Am. Chem. Soc. 38, 1885-1904.

Sherman, H. C.; Hendall, E. C: and Clark, E. D. 1910. Studies on Amylases. An Examination of the Nethods for the Determination of Methods for the Determination of Diastatic Power. Jour. Amer. Chem. Soc. 32, No.9, $1073-1086$. 

Sherman, H. C. and Purnett, P. W. 1916, Products of the Action of Certain Amylases upon Soluble Starch, with Special Reference to the Formation of Glucose. Jour. Am. Chem. Soc. $38, \quad 1877-35$.

Sherman, H. C. and Tanberg, A. P. 1916. Amylase of Aspergillus Oryzae. Jour. Am. Chem. Soc. 38, 1638-45.

Sherman, H. C., Thomas, A. W. and Baldwin, M. E. 1919. Influence of Hydrogen Ion Concentration upon Enzymes Activity of Three Typical Amylases. Jour. Am. Chem. Soc. 4l, 231.

Sherman, H. C. and Thomas, A. W. 1915. Studies on Amylases III. The Influence of Certain Acids and Salts upon the Activity of Malt Amylase. Jour. Am. Chem. Soc. 37, 623-43.

Sherman, H. C. and Thomas, A. W. 1917. A Noteworthy Effect of Bromides upon the Action of Malt Amylase. Jour. Am. Chem. Soc. $39,1501-3$.

Sherinan, H. C. and Walker, J. A. 1917. Influence of Certain Electrolytes upon the Course of the Hydrolysis of Starch by Malt Amylase. Jour. Am. Chem. Soc. 39, 1476-93.

Sherman, H. C. and Walker, Florence. 1919. Influence of Aspartic Acid and Asparagin upon the Enzyme Hydrolysis of Starch. Jour. Am. Chem. Soc. 41, 1866.

Sherman, H. C., Walker, Florence and Caldwell, Mary S. 1919. Action of Enzymes upon Starches of Different Origin. Jour. Am. Chem. Soc. 41, 1123.

Sherman, H. C. and Schlesinger. 1915. Studies on Amylases X. Comparison of Certa in Properties of Pancreatic and Malt Amylase Preparations. Jour. Am. Chem. Soc. 37, 1305.

Skaup. 1905. Nonatsh. Chem. 26, 1415.

Smith, E. F. 1905. Bacteria in Relation to Plant Diseases. Carnegie Insitution of Washington.

Swanson, C. O. and Calvin, J. W. 1913. A Preliminary Study on the Conditions which. Effect the Activity of Amylolytic Enzymes in Wheat Flour. Jour. Am. Chem. Soc. 35, 1636-37.

Synkiewski, W. 1902. Am. Chem. 324, 212.

Tanaka, Yoshio. 1912. Starch of Glutinous Rice and its Hydrolysis by Diastase. Jour. Ind. Eng. Chem. 4, 578-81.

Teff. 1894. Jour. of Physiol. "15, “421. 

Thatcher, R. W. and Koch, G. P., 1914. The Quantitative Extraction of Diastased From Plant Tissues. Jour. Amer. Chem. Society 36, 75I-759.

Thomas, A. W. 1915. The Chemical Constitution of Starch. Biochemical Bulletin 4, 379-397

Van Laer, H. 1912. Linit of the Diastasic Hydrolys is of Starch. Bull. Soc. Chim. Belg. 25, 393-411.

Waksman, S. A., 1920. A Method of Testing the Amylolytic Action of the Diastase of Aspergillus Niger. Jour. Amer. Chom Soc. 42, 293-299.

Waksman, S. A., 1919. Studies on the Metabolism of Actinoinyces, II. Jour. Bact. 4, 317-325.

Wohlgemuth, J., 1919. New Theories of the Formation and Action of Diastase. Biochem. Zeit. $94,213-224$.

Weijsmann, 1890. Rec. Trav. Chim. Pays-Bas. 9, 1.

Wortmann, Julius 1882. Untersuchungen Uber das diastatische Ferment der Bakterian. Zeit. Physiol. Chem. 6, 287330. 


UNIVERSITY OF ILLINOIS-URBANA

$$
30112079097769
$$

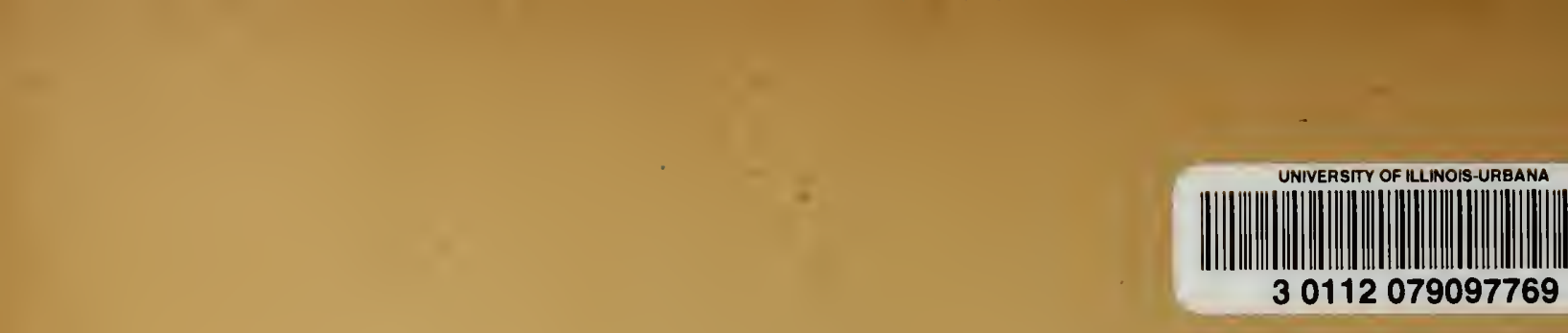

